\title{
THE GENUS SOROGEA ST. HIL. (MORAC.)
}

\author{
W. C. BURGER 1) \\ (Missouri Botanical Garden, Saint Louis) \\ AND \\ J. LANJOUW AND J. G. WESSELS BOER \\ (Botanical Museum \& Herbarium, Utrecht)
}

(received September 21th, 1962)

\section{INTRODUCTION}

The genus Sorocea was established by Aug. De Saint Hilaire (1821) in a study about the unequality of the cotyledons but he did not describe a species nor did he cite specimens. Gaudichaud's study (1844) gives only figures not accompanied by descriptions. The first publication with well-described and illustrated species of which the type-specimen is also well-perserved is MrQueL's treatment (1853) in Martius Flora Brasiliensis.

Balanostreblus, described and figured by KURz (1873) is known only from a cultivated specimen in the Calcutta herbarium and is undoubtedly conspecific with Sorocea guilliminiana. Three of the four Pseudosorocea species described by BAILLoN (1875) belong also to Sorocea.

The genus Paraclarisia, established by Ducke (1939), differs from Sorocea in the condensed and reduced inflorescences and the often more or less hirtellous, deciduous leaves. Till now the genus was monotypic, but $S$. saxicola, $S$. sprucei and $S$. arnoldoi agree very well with Paraclarisia amazonica and are congeneric with it. In the present paper Paraclarisia is given the rank of a subgenus within the genus Sorocea.

\section{MORPHOLOGY}

The Sorocea species are dioecious lactiferous unarmed shrubs and trees. Leaves alternate, distichous, 2-stipulate, pinnately veined, the petioles sulcate above. Stipules lateral, caducous or rarely persistent, their scars encircling less than half the stem. Inflorescences axillary on the younger branchlets, paired or solitary, racemose, spicate or capitate, with numerous suborbicular, usually peltate bracts along the rachis. Flowers unisexual, regular and basically tetramerous, often lacking along one side of the inflorescence. Staminate flowers: sessile or pedicellate, perianth 4-parted, the tepals equal or unequal, decussate-imbricate; stamens 4 , epitepalous, straight in the bud, straight

1) Present address: Imperial Ethiopian College of Agricultural and Mechanical Arts, Alemaya, Harar, Ethiopia. 
or variously disposed at anthesis, filaments glabrous, the anthers usually dorsifixed, dehiscing longitudinally and usually extrorse; pistillode rarely present. Pistillate flowers: sessile or pedicellate, the perianth tubular or rarely 4-parted and accrescent in fruit, irregularly or minutely 4-lobed at the apex, pistil 1, the ovary superior to inferior by adnation of the perianth tube, 2-carpellate, 1-locular, the ovule solitary, pendulous and anatropous, the style bifid, style branches usually short and broad with the inner stigmatic surface usually smooth. Fruit drupaceous, the perianth tube accrescent and succulent, the stone globose or ellipsoid, without endosperm, embryo large and straight with thick equal and partly fused cotyledons, the hypocotyl clearly differentiated.

The original description of Sorocea by St. Hilaire was accompanied by a discussion of the unequal cotyledons. St. Hilaire probably erred in interpreting the partly fused cotyledons as a single cotyledon and the plumule as a minute second cotyledon. The embryo of Sorocea resembles embryos of Clarisia and Trophis but differs in the fusion of the cotyledons and the larger hypocotyl.

The dioecious nature, variability of floral organs, and paucity of critical morphological structures upon which to base a classification have made this a difficult group to study. Fortunately two clearly distinguished groups of species present themselves and are given the rank of subgenera.

\section{The type of S. ILIGIfolia and the tyPe of THE genus Sorocea}

S. ilicifolia was described by MrQuel (1853) in the Flora Brasiliensis. The abbreviation "Mart." is found at the end of this description without any further notice. It presumably indicates a note by Martius.

The type specimens of Miquel's new species published in the Flora Brasiliensis are usually found both in the herbaria in Utrecht and in München, however there are no specimens bearing the name $S$. ilicifolia in Miquel's handwriting. The specimen mentioned by Chodat (1920) in his article on $S$. sylvicola is not the type; the leaves are much larger than described and the specimen bears male flowers, not mentioned in the description. Perhaps Miquel never saw a specimen of this species; he either copied the description of an unpublished note by Martius or he based the species on the description of the genus by St. Hilaire. St. Hilaire writes "Botecudis Soroco vernacule dicitur". Miquel states "in ditione indorum Botocudorum, quibus Soroco audit". This vernacular name which is not found elsewhere may indicate that Miquel copied his description from St. Hilaire. However, St. Hilaire describes the female flowers, Miquel only the vegetative parts of the plant; moreover Miquel's statement "Mart." at the end of the description is in that case incomprehensible, it was perhaps an error and should have been "St. Hilaire".

It is at present impossible to establish which plant Miquel meant to describe: the type does not exist. There are now more species with spinose leaves, so that it is not possible to ascertain to what species 
his description refers. As long as the type-specimen can not be traced it seems best not to use Miquel's name and to refer $S$. ilicifolia to the doubtful species.

St. Hilaire did not describe a species for his genus nor did he mention a type specimen. In the herbarium at Paris only one Sorocea collected by St. Hilaire could be traced: Aug. St. Hil. 131, Oct. 1838. This specimen, conspecific with $S$. guilliminiana, is not the type species. His description of a pistillate flower with a free perianth tube and a deeply bifid style suggests $S$. bonplandii. Since he resided in Rio Grande do Sul this is undoubtedly the species to which he referred though he may have had acces to collections of other species from Rio de Janeiro. For this reason $S$. bonplandii is choosen as the lectotype for the genus Sorocea.

\section{GeOGRAPHICAL DISTRIBUTION}

Sorocea ranges from an isolated collection in Guatemala to Paraguay and northernmost Argentina. Only one species is known from the West Indian Islands $S$. arnoldoi from Curaçao. Perhaps more intense collecting will reveal the presence of more Sorocea species from other West Indian Islands.

The genus is centered in the western Amazon region at the base of the Andes near the boundaries of Peru, Ecuador, Colombia, and Brazil where the greatest number of species are found (see map 1).

Of the 22 Sorocea species considered in this paper 14 occur here, of which 3 (S. briquetii, S. pileata, and S. opima), are endemic. Besides this primary centre there are two secondary centres of species concentration: one in Central America with 4 species of which 3 are endemic (S. cufodonti, S. pubivena, and S. affinis), and the other in Rio de Janeiro and the adjacent parts of eastern Brazil with 4 species of which 2 are endemic ( $S$. racemosa and $S$. guilliminiana).

From Central Brazil the genus is still unknown.

None of the species can be called widespread, they are usually restricted to a limited range.

The plants are generally components of the understory in moist, rarely flooded forests; from sealevel up to $2000 \mathrm{~m}$ altitude. Especially noteworthy is the fact that the two most specialized species from a morphological point of view, both of the subgenus Paraclarisia, have become adapted to the two environmental extremes in which the species of the genus are found: $S$. duckei grows in the inundated igapo of the Amazon basin and $S$. saxicola on rocky or saline soils in relatively dry woodlands of Bolivia and Paraguay.

Sorocea species are shrubs or small trees with inconspicuous inflorescences and without known economical uses, growing in dense forests. For this reasons they are probably usually overlooked and this may explain the scarcity or complete lack of material from many regions. $S$. saxicola is well represented in herbaria, probably due to the fact that this species grows more or less solitary on rocky and sandy soils, and not as the other species in dense forests. 

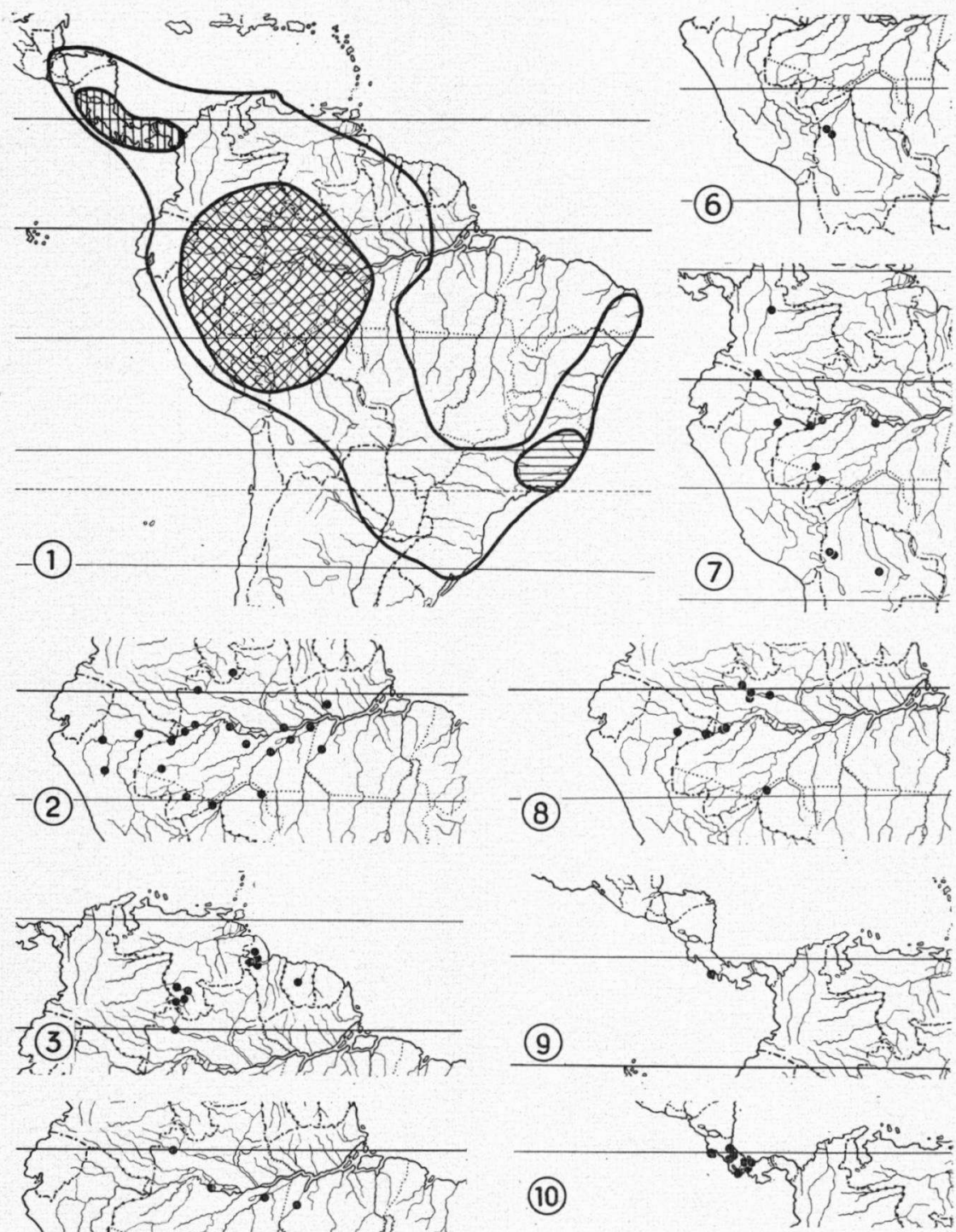

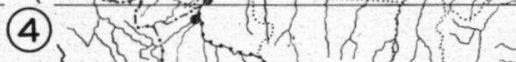
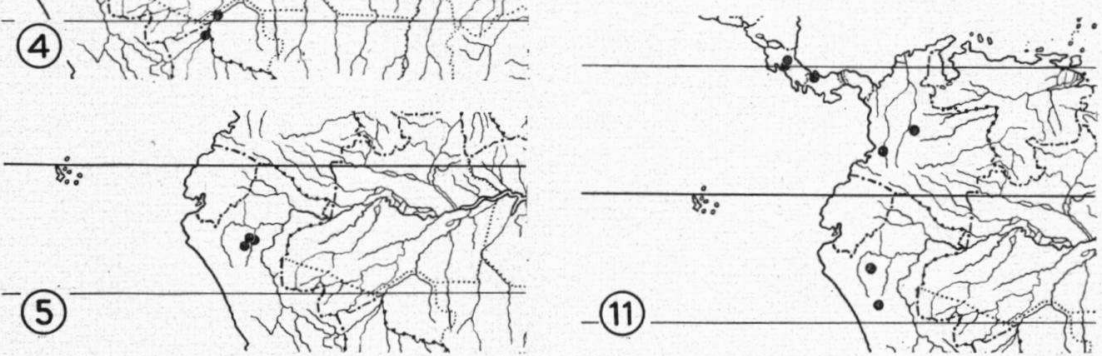

Map 1. Distribution of Sorocea as a whole. (Cross-hatched lines: primary centre of species concentration with 14 species of which 4 endemic; vertical lines: a secondary centre with 4 species of which 3 endemic; horizontal lines: another secondary centre with 4 species of which 2 endemic); Map 2. Sorocea muriculata; Map 3. S. guayanensis; Map 4. S. amazonica; Map 5. S. briquetii; Map 6. S. pileata; Map 7. S. hirtella; Map 8. S. opima; Map 9. S. cufodonti; Map 10. S. pubivena; Map 11. S. trophoides. 

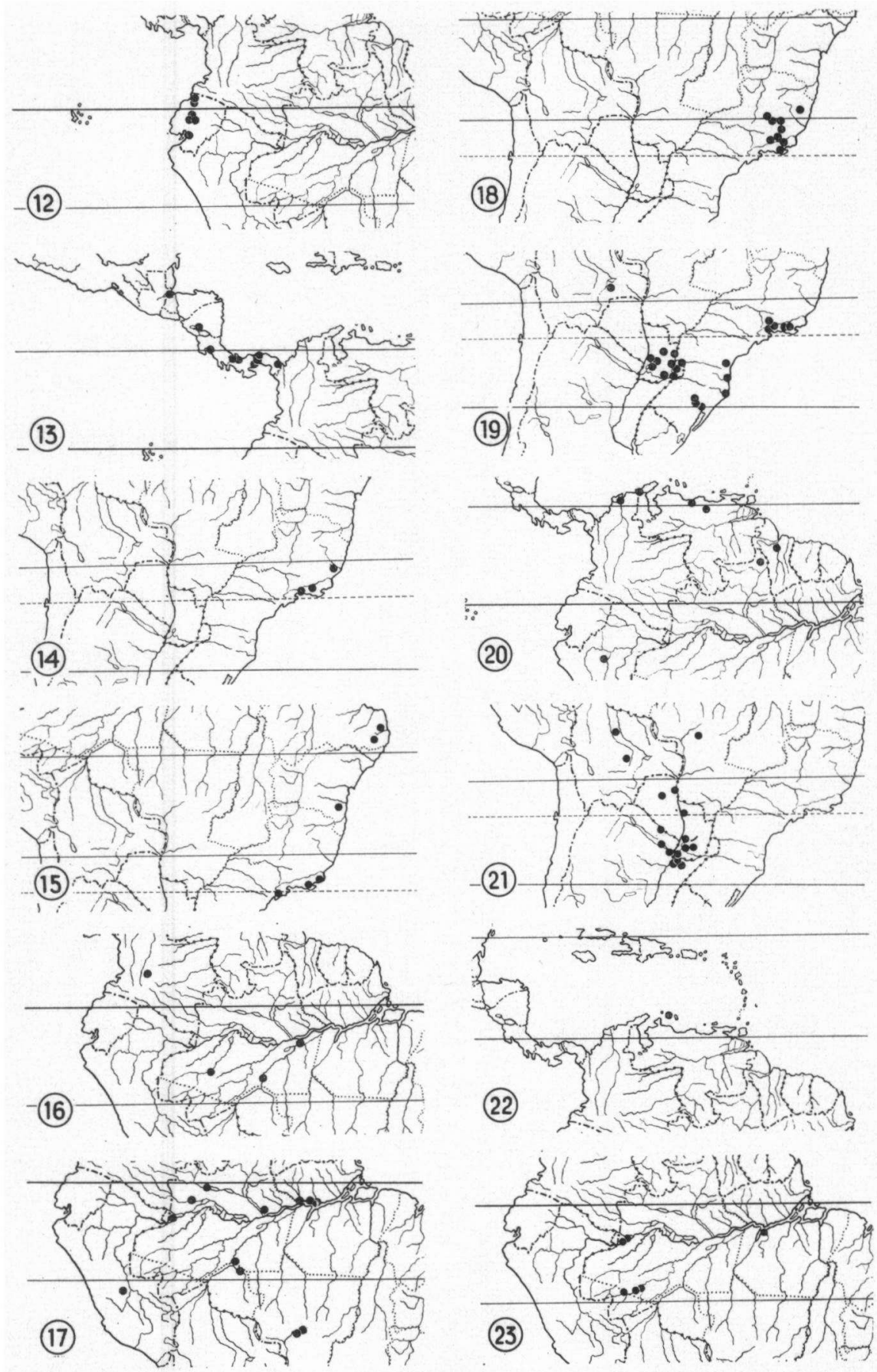

Map 12. S. sarcocarpa; Map 13. S. affinis; Map 14. S. racemosa; Map 15. S. hilarii; Map 16. S. macrogyna; Map 17. S. klotzschiana; Map 18. S. guilliminiana; Map 19. S. bonplandii; Map 20. S. sprucei; Map 21. S. saxicola; Map 22. S. arnoldoi; Map 23. S. duckei. 


\section{Material}

The present study is based on herbarium sheets of the following herbaria:

A Arnold Arboretum, Cambridge, Massachusetts-U.S.A.

B Botanisches Museum, Berlin-Dahlem, Germany.

BM British Museum of Natural History, London, Great Britain.

BR Jardin Botanique de l'Etat, Bruxelles, Belgium.

C Botanical Museum and Herbarium, Copenhagen, Denmark.

F Chicago Natural History Museum, Chicago, Illinois-U.S.A.

G Conservatoire et Jardin Botaniques, Geneve, Switzerland.

GH The Gray Herbarium of the Harvard University, Cambridge, Massachu-

K The Herbarium, Royal Botanic Gardens, Kew, Great Britain.

L Rijksherbarium, Leiden, Netherlands.

LIL Instituto Miguel Lillo, Tucuman, Argentina.

M Botanische Staatssammlung, München, Germany.

MG Museu Paraense Emilio Goeldi, Belem, Pará-Brazil.

MICH University Herbarium, University of Michigan, Ann Arbor, MichiganU.S.A.

MO Missouri Botanical Garden, Saint Louis, Missouri-U.S.A.

NY New York Botanical Garden, New York, New York-U.S.A.

P Muséum National d'Histoire Naturelle, Laboratoire de Phanérogamie, Paris, France.

RB Jardim Botânico, Rio de Janeiro, Brazil.

S Naturhistoriska Riksmuseum, Botanical Department, Stockholm, Sweden.

U Botanical Museum and Herbarium, Utrecht, Netherlands.

US National Museum, Smithsonian Institution, Washington, D.C.-U.S.A

YU Herbarium of the Yale University, Osborn Botanical Laboratory, New Haven, Connecticut.

Material from A, BM, C, F, GH, LIL, MG, MICH, MO, NY, P, RB, S, US, and $Y U$ is studied by the first author, material from B, BM, BR, F, G, GH, K, L, M, MO, NY, P, U, US by the last two authors. The authors are much indebted to the directors and curators of the above-mentioned herbaria for the generous loan of material.

\section{TAXONOMY}

Key to the subgenera

a. Staminate and fruiting inflorescences spikes or racemes; staminal filaments over $0,4 \mathrm{~mm}$ long at anthesis, free or slightly connate at the base; leaves persistent ......... I sOROCEA

b. Staminate and fruiting inflorescences capitate or occasionally condensed spikes or racemes or reduced to 1-3 pistillate flowers; staminate filaments connate into a column less than $0,5 \mathrm{~mm}$ long; leaves usually deciduous ........ II PARACLARISIA

\section{SUBGENUS I SOROCEA}

Shrubs and trees to $20 \mathrm{~m}$ tall; branchlets usually with distant nodes and smooth leaf scars. Leaves evergreen, elliptic to oblong, obovate, or ovate, acute to narrowly acuminate at the apex, acute to obtuse at the base, membranaceous to pergamentaceous, smooth above and glabrous or variously puberulent beneath, the tertiary veins prominulous or plane below, the margin entire to serrulate or spinulosedentate. Staminate inflorescences elongate spikes or racemes; stami- 
nate flowers with equal or unequal perianth parts, staminal filaments over $0,5 \mathrm{~mm}$ long, free or slightly connate at the base. Pistillate inflorescences racemose or spicate and usually elongating in fruit; the embryo with cotyledons about three-quarters united.

Distributed from Guatemala to Paraguay and northern Argentina, in moist forests that are rarely flooded or wooded slopes along watercourses.

Key to the species

1. a. Leaves entire to bluntly serrate, never spinulose-dentate nor sharp-tipped; ovary usually free or only in the lower part grown to the perianth tube; staminate flowers sessile or when pedicellate with short staminal filaments, straight, bent inward or rarely bent outward at anthesis. . . .

b. Leaves spinulose-dentate and sharp-tipped; ovary usually grown to the perianth tube; staminate flowers always pedicellate and with rather long staminal filaments, usually bent outward at anthesis. . . . . . . .

2. a. Stipules often persistent; peduncles 20-150 mm long, bracts of the rachis $0,1-0,8 \mathrm{~mm}$ broad; pistillate flowers and fruit reflexed on the inflorescences.

13. S. racemosa (Eastern Brazil)

b. Stipules caducous; peduncles 2,5-30 mm long, bracts of the rachis to $2,5 \mathrm{~mm}$ broad; pistillate flowers and fruit perpendicular to the rachis.

3. a. Leaves with a marginal vein only slightly arcuate between adjacent secondary veins; pistillate flowers usually less than 12 and distant along the rachis, usually over $3 \mathrm{~mm}$ long at anthesis. . . . . 7. S. opima (Amazon basin)

b. Leaves with the marginal veins conspicuously arcuate between adjacent secondary veins; pistillate flowers usually numerous and approximate, less than $3 \mathrm{~mm}$ long at anthesis. . . . . . . . . . . . . . .

4. a. Leaves usually entire; perianth tube not forming a collar at the apex of the developing fruit; anthers emarginate.

b. Leaves frequently serrulate; perianth tube forming a collar at the apex of the developing fruit; connective of the anthers usually prolonged in a gland-like tip.

5. a. Pistillate flowers conic at anthesis, padicel broader than the base of the flower and accrescent in fruit; staminate flowers crowded, stamens usually unequal.

b. Pistillate flowers globose or ovoid at anthesis, pedicel much narrower than the flower and fruit; staminate flowers usually distant, the stamens equal. ..... 
6. a. Petioles $5-22 \mathrm{~mm}$ long, leaves usually obovate, perianth of the pistillate flowers glabrous; stamens bent outward at anthesis on thick filaments. . . . . . . . 6. S. hirtella (Colombia to the Amazon basin and Bolivia)

b. Petioles $2-8 \mathrm{~mm}$ long, leaves often elliptic; perianth of pistillate flowers and the fruit warty or hirtellous; stamens straight or bent inward at anthesis on slender filaments.

7. a. Leaves usually narrowly elliptic, perianth of the pistillate flowers and fruit warty; fruits not fleshy; staminate flowers with 4-6 perianth parts and stamens, and often with a pistillode. . . 1. S. muriculata (Amazon basin)

b. Leaves more broadly elliptic to narrowly obovate, pistillate flowers and young fruits hirtellous, mature fruits black fleshy, staminate flowers 4-fid without a pistillode.

2. S. guayanensis

(Venezuela, Brit. Gui., Suriname, and n. Brazil)

8. a. Staminate flowers with a prominent ovoid pistillode, broadly sessile. . . . . 8. S. cufodonti (Costa Rica)

b. Staminate flowers without a pistillode, sessile or pedicellate. . . . . . . . . . . . . .

9. a. Leaves acuminate to abruptly caudate-acuminate; developing fruit globose or ovoid.

b. Leaves acute or gradually acuminate; developing fruit cylindrical to ellipsoid or ovoid and tapering to a conic apex................

10. a. Pistillate flowers urceolate, ovary free within the perianth tube at anthesis; staminal filaments 1,8-2,6 mm long, anthers $0,7-11 \mathrm{~mm}$ long. . . . . . . . . . 10. S. trophoides (Costa Rica to Peru above $1000 \mathrm{~m}$ alt.)

b. Pistillate flowers ovoid, globose or obovoid, ovary partly or wholly grown to the perianth tube at anthesis; staminal filaments $1,1-2,0 \mathrm{~mm}$ long, anthers $0,4-0,8 \mathrm{~mm}$ long.

11. a. Leaves broadly elliptic to oblong, usually puberulent beneath; fruiting pedicels $1,6-2,8 \mathrm{~mm}$ in diameter or the fruit sometimes sessile; staminate flowers sessile. . . . 9. S. pubivena (Costa Rica and n. Panama)

b. Leaves narrowly elliptic to obovate, glabrous; fruiting pedicels $0,7-1,7 \mathrm{~mm}$ in diameter; staminate flowers pedicellate or sessile.

12. a. Leaves elliptic to elliptic-oblong; staminate flowers usually pedicellate; fruits short pubescent, becoming red on pink pedicels. . 12. S. affinis (Guatemala to Panama)

b. Leaves obovate; staminate flowers sessile, fruits glabrous, black fleshy on fleshy pedicels.

11. S. sarcocarpa (Ecuador) 
13. a. Leaves obovate to spathulate, rather sharp-tipped; pistillate flowers not contiguous, fruiting inflorescences $5 \mathrm{~cm}$ or longer; staminate flowers pedicellate. 14. S. hilarii (Eastern Brazil: Sao Paulo to Paraiba)

b. Leaves usually elliptic to ovate, the acumen rounded at the tip; pistillate flowers contiguous; staminate flowers unknown. . . . . . . . . . . . . . .

14. a. Leaves narrowly elliptic with 7-12 pairs of secondary veins, acuminate; mature fruit about $7 \mathrm{~mm}$ long. .

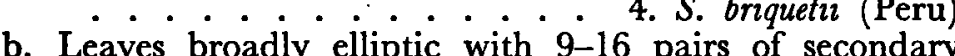
veins, acute to subacuminate; mature fruit about $12 \mathrm{~mm}$ long. . . . . . . . . 5. S. pileata (Bolivia)

15. a. Pistillate flowerss with long recurved, finely papillose style branches, ovary free or only in the lower part grown to the perianth tube and glabrous; staminal filaments slender $(0,1-0,3 \mathrm{~mm})$, slightly connate at the base.

18. S. bonplandii

(Eastern Brazil to Paraguay and Argentina)

b. Pistillate flowers with short style branches, ovary usually half to wholly grown to the perianth tube and minutely puberulent; staminal filaments thick, wholly free. . .

16. a. Leaves chartaceous, style branches short and inconspicuous, ovule very large; fruiting pedicels slender; staminal filaments narrowed in the distal part.

- 15. S. macrogyna (Amazon basin and s. Colombia)

b. Leaves (sub)coriaceous; style branches larger and thick, ovule normal, fruiting pedicels $1 \mathrm{~mm}$ in diameter or more; staminal filaments not narrowed in the distal part.

17. a. Leaves narrowly elliptic-oblong to lanceolate; pistillate flowers muricate, sparsely puberulous; fruit muricate, not fleshy.

17. S. guilliminiana (Eastern Brazil: Rio de Janeiro)

b. Leaves more broadly oblong-elliptic, pistillate flowers almost smooth, densely and minutely puberulous, fruit smooth, black fleshy in maturity. . . . . . 16. S. klotzschiana (Amazon basin)

1. Sorocea muriculata Miquel in Martius, Fl. Bras. 4 (1): 113, t 34. 1853; Huber, Bol. Mus. Pará 5: 333. 1909; Macbride, Field Mus. Bot. 13 (2); 312.1937.

Type: Martius s.n. + , from vicinity of Ega, Amazonas, Brazil (M).

Heterotypic synonyms: Pseudosorocea uaupensis Baillon, Adansonia 11: 297. 1875; Sorocea uaupensis (Baillon) Macbride, Candollea 5: 349. 1934. Type: Spruce 2715 ơ, from Rio Uaupes near Panuré, Amazonas, Brazil. (P). 
Sorocea cuspidata Warburg, nomen nudum, Bot. Jahrb. 40: 137. 1907.

Sorocea dentata Huber, Bol. Mus. Pará 5: 333. 1909. Type: Ducke 8957 으, from Rio Trombetas, Pará, Brazil (MG).

Plate I: Fig. 1, 2, 3

Leaves narrowly elliptic to oblong, acuminate, chartaceous, glabrous; margin entire or slightly serrulate. Staminate inflorescences spicate with many sessile flowers; number of tepals and stamens varies frcm 4-6, anthers emarginate; sometimes a pistillode present. Pistillate flowers and young fruits sparsely hirtellous and muriculate. Fruit globose, about $6 \mathrm{~mm}$ in diameter, muriculate to smooth; fruiting pedicels to $4 \mathrm{~mm}$ long, about $1 \mathrm{~mm}$ in diameter.

Shrubs or trees to $12 \mathrm{~m}$ tall; leafy branchlets $0,7-2,2(-4,0) \mathrm{mm}$ in diameter, minutely and densely puberulent, becoming glabrous, the lenticels small and inconspicuous. Leaf blades narrowly elliptic to oblong or ovate, $5,5-16,4 \mathrm{~cm}$ long, $2,0-4,5(-5,2) \mathrm{cm}$ broad, acuminate, obtuse at the base, membranaceous to chartaceous, glabrous, the midvein slightly impressed above, prominent beneath with 8-11 pairs of ascending secondary veins arching upward to form a marginal vein near the entire or occasionally serrulate margin; petioles $1,3-4,0(-6,5) \mathrm{mm}$ long, $0,7-1,3(-1,7) \mathrm{mm}$ in diameter, densely and minutely puberulent. Stipules caducous, cuneate, $2-4 \mathrm{~mm}$ long, their scars small and inconspicuous. Staminate inflorescences: spicate, paired or solitary in the axils of leaves or fallen leaves, 8-47 $\mathrm{mm}$ long, the peduncle 2,0-6,5 mm long, sparsely and minutely puberulent, the rachis with a few orbicular or cuneate, basally attached or peltate bracts $0,6-1,3 \mathrm{~mm}$ broad; flowers 12 to numerous and crowded at first but distant at anthesis, sessile, about $1,5 \mathrm{~mm}$ long and 2,5-5,0 mm broad, number of tepals varying from 4-6, stamens epitepalous and equal in number, the perianth parts free and usually unequal, often arising separately from the rachis, about $1,2 \mathrm{~mm}$ long, obtuse at the apex and sparsely puberulent, staminal filaments $0,3-0,7 \mathrm{~mm}$ long, about $0,2 \mathrm{~mm}$ in diameter, the anthers about $0,5 \mathrm{~mm}$ long, occasionally bent inward at anthesis, emarginate; a small lingulate pistillode sometimes present in the centre of the flower. Pistillate inflorescences: spicate to racemose, paired or solitary in the axils of leaves or fallen leaves, 4-35 mm long, the peduncles $1,2-3,5 \mathrm{~mm}$ long, minutely puberulent, the rachis with suborbicular peltate or basally attached bracts $0,5-1,3$ $\mathrm{mm}$ broad; flowers 6-15 and crowded at first, becoming distant, subsessile and becoming pedicellate in fruit, perianth tube minutely 4-lobed at the apex or rarely deeply 4-parted, globose to ovoid, about $2 \mathrm{~mm}$ in diameter, sparsely and minutely hirtellous to muriculate, the ovary free or rarely partly grown to the perianth tube at anthesis, the style branches $0,2-0,6 \mathrm{~mm}$ long. Fruit globose, about $6 \mathrm{~mm}$ in diameter, muriculate to smooth and glabrescent, becoming red at maturity, the fruiting pedicels to $4 \mathrm{~mm}$ long, about $1 \mathrm{~mm}$ in diameter.

Flowering from August to March.

Distribution: The Amazon basin of Venezuela, Peru, Brazil and northern Bolivia (map 2). In moist forests and the mata de terra firma and the várzeas at altitudes below $800 \mathrm{~m}$.

Venezuela: Amazonas: Sierra Parima, Cardona 1344 (US).

Peru: Loreto: Mishuyacu, near Iquitos, Klug 153 (F); mouth of Santiago, Tessmann 4059 o (B, F, S), 4111 (B, S); Iquitos, L1. Williams 8010 o (F, U). SAN MArTin: Chazuta, Río Huallaga, Klug 3984 o (BM, GH, F, MO, NY, S); Maynas, Poeppig $2325 \delta^{*}(\mathrm{~B}, \mathrm{~F}, \mathrm{~L})$.

BrAzIL: ACRE: Near mouth of Rio Macauhan, Krukoff 5250 ㅇ (BM, F, MO, S, U), 5290 \% (MO, S), 5352 o (BM, F, MO, S, U), 5513 (F); Rio Abunan, Kuhlmann 708 o (RB). Amazonas: Manáos, Igarapé do Buiáo, Chapas-INPA 229 ðै (MG); Esperança, boco do Rio Javary, Ducke 25254 ๆ (RB), 1040 \& (MG, 


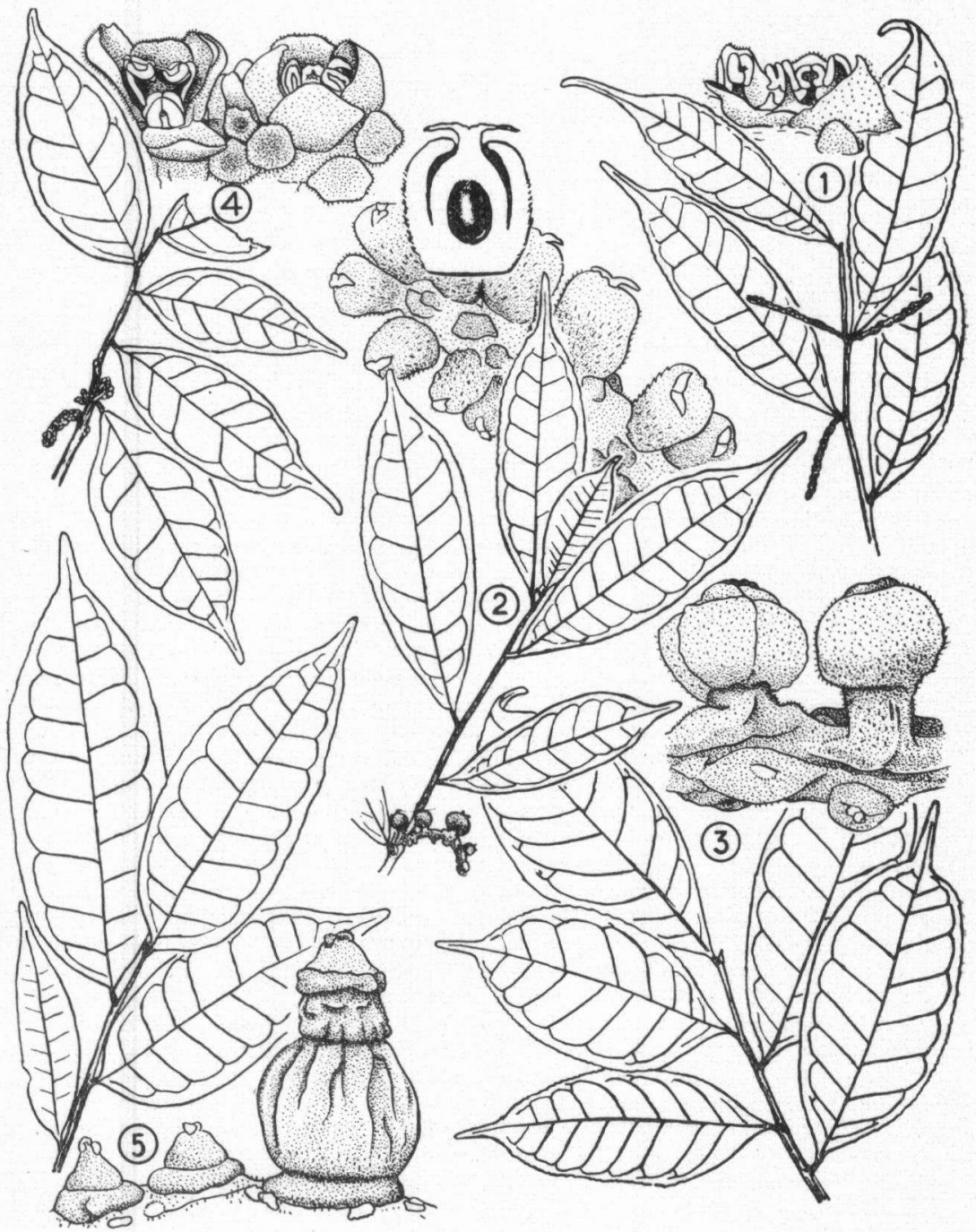

Plate I. Sorocea muriculata: from Klug 153 (fig. 1), Spruce 4059 (fig. 2), and Krukoff 6988 (fig. 3). Sorocea amazonica: from Krukoff 5982 (fig. 4), and Fróes 21448 (fig. 5).

MO, NY, RB); Manáos, Ducke 25255 \& (RB), 25256 ơ (RB); Rio Javary, Ducke 7458 † (BM); Sto Antonio do Içá, Ducke 7670 J (BM, F, S); Borba, near Bella Vista, Krukoff 5977 ㅇ (BM, F, MO, NY, U, US) ; Humayatá, near Livramento, Krukoff 6988 q (BM, F, MO, NY, S, U); São Paulo de Olivença, near Palmares, Krukoff 8520 o (BM, F, MICH, MO S, U); Democracia, Madeira, Kuhlmann 256 (RB); Boca do Rio Branco, Kuhlmann 1103 q (RB); vicinity of Ega, Martius s.n. ๆ (M, U); Maués, Murça Pires 71 q (US); near Ega, Poeppig 2581 B . (B) 2582 ㅇ (B), 8581 pp o (L); Panuré, ad Rio Uaupés, Spruce 2715 đ (B, K, P); vicinity of Barra, Rio Negro, Spruce s.n. \& (B, BM, C, P); Rio Juruá, Juruá miry, 
Ule 5869 đ (B, F, L, MG). Matro Grosso: Tabajara, upper Machado River,

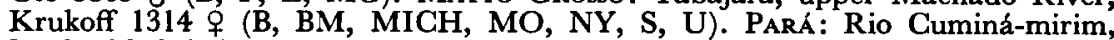
Ducke 7959 \& (BM, MG, RB); Rio Trombetas, cachoeira Porteira, Ducke 8957 오 (BM, MG, RB, US); Vila nova, Rio Tabajos, Murça Pires 3539 ㅇ (US).

Bolrvia: Serra, Kuhlmann 576 o (RB).

The pistillate flowers of Krukoff 5250 are usually 4-parted and the inflorescence is in several instances terminated by staminate flowers with pistillodes. This anomalous collection is identical in all other respects with typical specimens of the species.

The fruit of several collections (Spruce s.n., Krukoff 6988) appear to have an accrescent 4-parted perianth and several staminate collections (Tessmann 4059, Klug 153) have occasional pistillodes. These collections, similar in other respects to typical $S$. muriculata, delimit a broad range of floral variation within the species.

Specimens from Pará occasionally possess serrulate or denticulate leaves. The name $S$. dentata has been applied to such collections but they seem hardly worthy of varietal status.

2. Sorocea guayanensis $W$. Burger nov. spec.

Type: L1. Williams 14532 \&, from Rio Sanariapo, Amazonas, Venezuela, ( $F$, isotype in $G$ ). Plate II: Fig. 1

Folia elliptica ad anguste obovata, acuminata, integerrima, chartacea, glaberrima, nervis secundariis 7-12-jugis. Inflorescentiae masculae floribus crebris, basi lata sessilibus, antheris in anthesi inflexis, emarginatis. Inflorescentiae femineae breves, floribus $5-15$, dense hirtellae; ovarium tubo perianthii (infra) adnatum. Drupa ovoidea, hirtella, glabrescens, matura atroviolacea carnosaque. ${ }^{1}$ )

Shrubs or trees to $6 \mathrm{~m}$ tall; leafy branchlets $1,0-2,5 \mathrm{~mm}$ in diameter, minutely puberulent, soon becoming glabrous, the lenticels small and often prominent. Leaf blades elliptic to narrowly obovate, 9-22 cm long, 3-7 cm broad, acuminate, acute to obtuse at the base, chartaceous, glabrous, the midvein plane or slightly impressed above and prominent beneath with 7-12 pairs of ascending secondary veins, forming an arcuate marginal vein near the entire margin, petioles 3-8 $(-12) \mathrm{mm}$ long, their scars small. Staminate inflorescences: spicate, paired or solitary in the axils of leaves or fallen leaves, about $25 \mathrm{~mm}$ long, the peduncles less than $2 \mathrm{~mm}$ long, the rachis with numerous suborbicular, basally attached or peltate bracts $0,5-1,1 \mathrm{~mm}$ broad, flowers numerous and crowded, broadly sessile, about $1,5 \mathrm{~mm}$ long and to $2,5 \mathrm{~mm}$ broad, the perianth parts free and subequal, about 1,3 $\mathrm{mm}$ long, obtuse at the apex, minutely fimbriate, staminal filaments about $1,0 \mathrm{~mm}$ long, slender, the anthers $0,4 \mathrm{~mm}$ long, bent inward at anthesis, emarginate. Pistillate inflorescences: racemose, paired or solitary in the axils of leaves or fallen leaves, 7-28 $\mathrm{mm}$ long, the peduncle $0,5-3,3 \mathrm{~mm}$ long, densely puberulous, the rachis with numerous suborbicular basally attached or peltate bracts, 0,6-1,4 mm broad, flowers 5-15 per inflorescence, subsessile or pedicellate, hirtellous at first, perianth tube obovoid, about $2 \mathrm{~mm}$ in diameter, ovary grown to the perianth tube or free in the upper part, the style branches $0,5-1,0 \mathrm{~mm}$ long and often recurved. Fruit short pedicellate, ellipsoid to ovoid, about $10 \mathrm{~mm}$ long, hirtellous, becoming glabrous and purple-black fleshy at maturity.

1) The authors are very much indepted to Dr. K. U. Kramer who has contributed the latin diagnoses. 
Distribution: Venezuela, British Guiana, Suriname and the Rio Negro basin of Brazil (map 3). In moist forests and along watercourses at lower elevations.

British Guiana : Essequibo: Cuyuni River, Bartlett 8383 o (K, U); Tiger Creek, Lower Essequibo River, Forest Dept. 3073 \% (U), 3074 \& (S, U); Jenman 1183 $\delta(\mathrm{K}), 2480$ o $(\mathrm{K})$; Kurupung, Tacoba, Lang \& Persaud s.n. ${ }^{\circ}$ (F).

Suriname: Upper Suriname River near Goddo, Stahel 143 \& (U).

Venezuela: Amazonas: La Isla de El Ratón, L1. Williams 13443 q (US); margen del Río Saariapo, L1. Williams 13488 q (F, US); San Carlos de Río Negro, L1. Williams 14532 q (F, G); San Antonio, Río Orinoco, Ll. Williams 15079 \& (G, US); Casiquare, Río Orinoco, L1. Williams 15184 ㅇ (G).

Brazil: Amazonas: Serra de São Gabriel, Murça Pires 555 o (US).

The hirtellous pistillate flowers with the ovary adnated to the perianth tube, the purple-black fleshy fruit, and the small staminate flowers with the anthers bent inward at anthesis distinguish this species from its closest relatives $S$. muriculata and $S$. amazonica.

$S$. guayanensis is the only species of the subgenus Sorocea known from British Guiana and Suriname.

3. Sorocea amazonica Miquel in Martius, Fl. Bras. 4 (1): 111, t 34, f 2. 1853; Macbride, Field Mus. Bot. 13 (2): 312.1937.

Type: Martius s.n. + , from vicinity of Ega, Amazonas, Brazil (M). Plate I: Fig. 4, 5

Leaves narrowly ovate to elliptic, acuminate, chartaceous, glabrous, the margin entire or slightly serrulate, petioles $1,8-5,0 \mathrm{~mm}$ long. Staminate inflorescences 7-35 mm long; flowers crowded, sessile, perianth parts and stamens 4 , anthers unequal in size. Pistillate flowers conic at anthesis; pedicel broader than the base of the flower and accrescent in fruit. Fruit globose and conic tipped, glabrous.

Shrubs or trees to $8 \mathrm{~m}$ tall; leafy branchlets $0,8-2,7 \mathrm{~mm}$ in diameter, minutely and densely puberulent, glabrescent, the lenticels small and inconspicuous. Leaf blades narrowly ovate to elliptic or elliptic-oblong, $6-14 \mathrm{~cm}$ long, $1,5-5,5 \mathrm{~cm}$ broad, acuminate, acute to obtuse at the base, chartaceous, glabrous, the midvein impressed above and prominent beneath with 6-10 pairs of ascending secondary veins forming an arcuate marginal vein near the entire or slightly serrulate margin, petioles 1,8-4,5 $\mathrm{mm}$ long, about $1 \mathrm{~mm}$ in diameter. Stipules caducous, narrowly cuneate, 2-4 $\mathrm{mm}$ long, their scars small and inconspicuous. Staminate inflorescences: spicate, paired or solitary or occasionally in clusters in the axils of leaves or fallen leaves, 7-35 $\mathrm{mm}$ long, the peduncles less than $2 \mathrm{~mm}$ long, the rachis with suborbicular or cuneate, peltate or basally attached bracts about $0,8 \mathrm{~mm}$ broad; flowers numerous and crowded, sessile, about $1,5 \mathrm{~mm}$ long and $3,0 \mathrm{~mm}$ broad, the perianth parts free and usually unequal, obtuse at the apex and minutely puberulent near the margin, staminal filaments about $0,8 \mathrm{~mm}$ long, slender, the anthers frequently of two sizes within each flower, the smaller about $0,3 \mathrm{~mm}$ long, the larger about $0,5 \mathrm{~mm}$ long, emarginate. Pistillate inflorescences: spicate becoming racemose, paired or solitary in the axils of leaves or fallen leaves, $7-25 \mathrm{~mm}$ long, the peduncles less than $2 \mathrm{~mm}$ long, the rachis with suborbicular to cuneate, peltate or basally attached bracts about $0,8 \mathrm{~mm}$ broad; flowers $8-15$, the pedicel wider than the young flower and becoming larger than the developing fruit, perianth tube subentire at the apex, conic, about $1,8 \mathrm{~mm}$ in diameter, glabrous, the ovary free within the perianth tube, the style branches about $0,4 \mathrm{~mm}$ long. Fruit globose and conic-tipped, about $0,5 \mathrm{~mm}$ in diameter, smooth and glabrous, the fruiting pedicel equaling or thicker than the fruit.

Flowering from September to October. 
Distribution: Bolivia and Brazil (map 4). In the mata de terra firma of the Amazon basin.

Bolrvia: Pando: junction of the rivers Beni and Madre de Dios, Rusby 2217 of (NY, P).

Brazil: Amazonas: São Gabriel, Pôrto de Curucuhy, Rio Negro, Fróes 21448 오 (NY); Foz do Caiary, Rio Negro, Fróes 22163 ơ (U); Borba, near Bella Vista, Krukoff 5982 ơ (A, BM, F, MO, NY, S, U); near Ega, Martius s.n. \& (M, U); falls of Madeira, Rusby 2578 oै (NY). ParÁ: Francez, Seringal Palhal, on Rio Tapojoz, Ducke 18318 oै (B, S, U).

The greatly thickened pedicels of the pistillate flowers are unique to the species. Plate I figure 4 and 5 illustrate our concept of the species but though the staminate and pistillate foliage match rather closely there is a possibility that they do not belong together and the species as here defined may prove heterogenous.

The Rusby collections cited above may be incorrectly labeled and represent a single collection. A specimen collected by Poeppig (2563) near Ega has been photographed and prints have been distributed as photographs of the type of $S$. amazonica, but this collection is referable to $S$. hirtella.

4. Sorocea briquetii Macbride, Candollea 4: 311. 1931; Macbride, Field Mus. Bot. 13 (2): 311. 1937.

Type: Spruce 4220 o, from San Martín, near Tarapoto, Peru (G). Plate II: Fig. 2

Leaves narrowly elliptic, gradually acuminate, the acumen rounded at the tip, chartaceous, glabrous, lustrous above, the margin serrulate, petioles 3-9 mm long, blackish. Staminate inflorescences unknown. Pistillate inflorescences 1,5-6 cm long; flowers sessile, closely contiguous at first, becoming distant in fruit. Fruit cylindrical, glabrescent, with about $6 \mathrm{~mm}$ long pedicels.

Shrubs or small trees to $6 \mathrm{~m}$ tall; leafy branchlets $0,8-2,8 \mathrm{~mm}$ in diameter, sparsely and minutely puberulent or glabrous, the lenticels usually prominent on younger parts. Leaf blades narrowly elliptic to elliptic-oblong or narrowly obovate, $7-13 \mathrm{~cm}$ long, $2,5-4,0(-5,5) \mathrm{cm}$ broad, acuminate, acute or occasionally obtuse at the base, pergamentaceous to chartaceous, glabrous and lustrous above, glabrescent below, the midvein plane or slightly impressed above, prominent below with 7-12 pairs of ascending secondary veins arching upward near the bluntly serrulate to entire margin and usually forming an arcuate marginal vein; petioles 3,5-9,0 $\mathrm{mm}$ long, $0,8-1,4 \mathrm{~mm}$ in diameter, minutely puberulent and glabrescent. Stipules caducous, lanceolate, 2,8-5,0 mm long, their scars inconspicuous. Pistillate inflorescences: spicate to racemose, paired or solitary in the axils of leaves or fallen leaves, $1,2-6,5 \mathrm{~cm}$ long and elongating in fruit, the peduncles $2,5-4,5 \mathrm{~mm}$ long, minutely puberulent, the rachis with numerous suborbicular, often long-stalked peltate bracts about $1 \mathrm{~mm}$ broad; flowers numerous and densely crowded at first, becoming distant, sessile but becoming pedicellate in fruit, perianth tube subentire at the apex, globose or ovoid but becoming thickened above, often angular in early stages by contact with the adjacent flowers, $1,2-2,0 \mathrm{~mm}$ in diameter, glabrous on the upper half, minutely puberulent below, the ovary partly grown to the perianth tube, style branches about $0,7 \mathrm{~mm}$ long. Fruit cylindrical or ellipsoid, becoming globose, about $7 \mathrm{~mm}$ long and $5 \mathrm{~mm}$ in diameter, glabrescent, the fruiting pedicels about $6 \mathrm{~mm}$ long and $1 \mathrm{~mm}$ in diameter.

Flowering in November and December. 


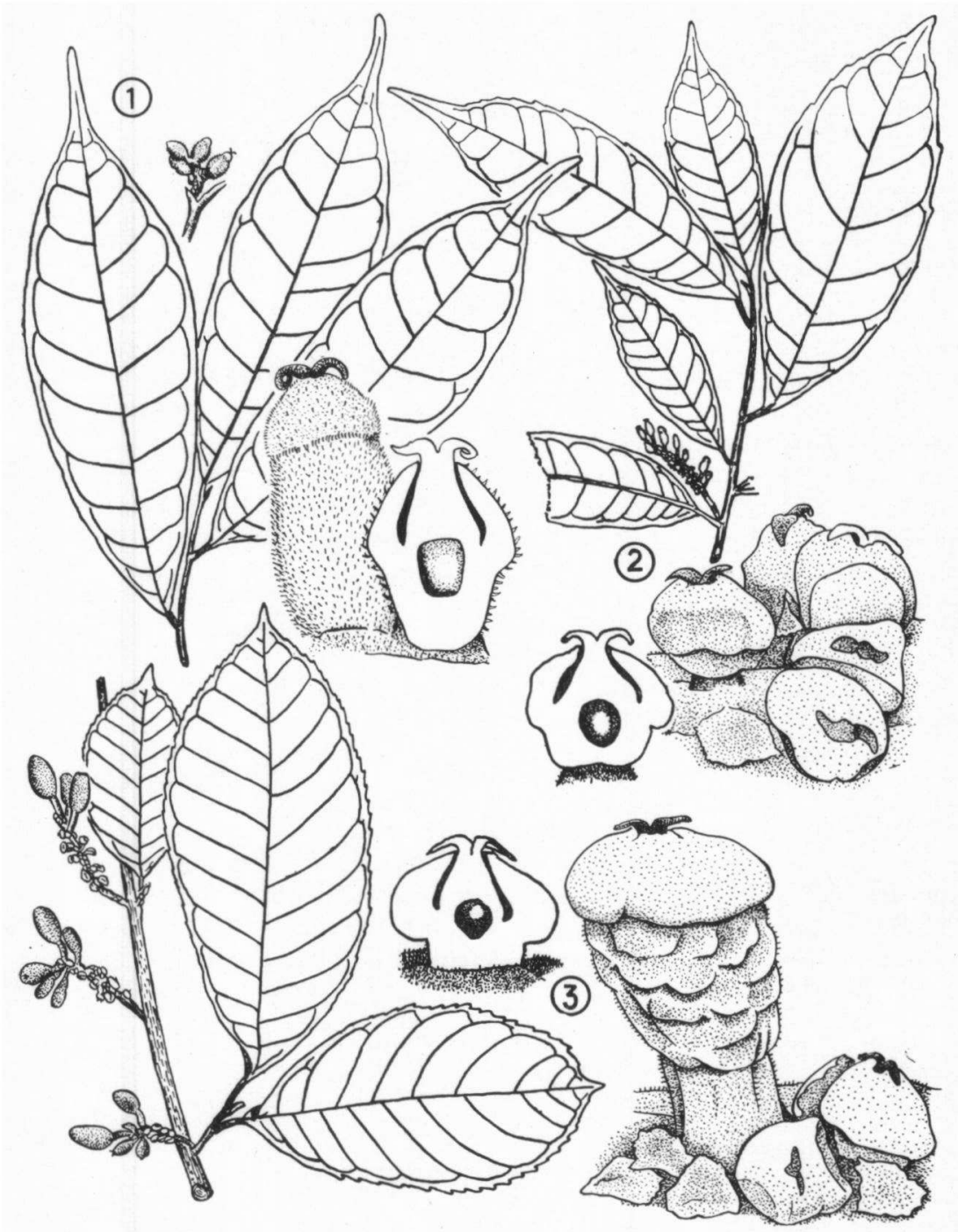

Plate II. Sorocea guayanensis: from L1. Williams 14532 (fig. 1). Sorocea briquetii: from Spruce 4220 (fig. 2). Sorocea pileata: from R. S. Williams 412 (fig. 3).

Distribution: Eastern Peru (map 5). In forests from 300-900 m altitude.

Peru: San Martin: Juanjui, Alto Río Huallaga, Klug 4161 o (A, F, MO, S); near Tarapoto, Spruce 4220 i (B, BM, C, F, G, S); Runuzapa, near Tarapoto, L1. Willams $6803+(F)$.

5. Sorocea pileata $W$. Burger nov. spec.

Type: R. S. Williams 412 o, from Ixiamas, Bolivia (NY). 
Folia late elliptica ad oblongo-elliptica, abrupte subacuminata, pergamentacea, glabra, serrata, nervis secundariis 9-16-jugis. Inflorescentiae femineae spicatae vel racemosae, floribus 10 vel ultra, imprimo sessilibus; ovarium tubo perianthii infra adnatum; fructus ellipsoidus, pedicello ad $8 \mathrm{~mm}$ longo et $2 \mathrm{~mm}$ crasso munitus.

Probably shrubs or small trees; leafy branchlets $2-4 \mathrm{~mm}$ in diameter, minutely puberulent, glabrescent, the lenticels prominent. Leaf blades broadly elliptic to oblong-elliptic, 7-19 $\mathrm{cm}$ long, 3,5-7,2 $\mathrm{cm}$ broad, the apex broadly rounded, abruptly subacuminate, obtuse to acute at the base, pergamentaceous, glabrous, the midvein plane or slightly impressed above, prominent below with 9-16 pairs of ascending secondary veins arching upward near the serrulate margin and usually forming an arcuate marginal vein; petioles $6-13 \mathrm{~mm}$ long, 1,2-2,4 $\mathrm{mm}$ in diameter, minutely puberulent and glabrescent. Stipules caducous, cuneate, 4-7 mm long, their scars conspicuous. Staminate inflorescences unknown. Pistillate inflorescences: spicate, becoming racemose in fruit, paired or solitary in the axils of leaves or fallen leaves, $1,3-5,8 \mathrm{~cm}$ long, the peduncles about $1 \mathrm{~mm}$ long, minutely puberulent, the rachis with numerous suborbicular peltate bracts, $1-2 \mathrm{~mm}$ broad; flowers 10 to many per inflorescence, crowded, sessile at first but becoming pedicellate in fruit, perianth tube ovoid, about $1,5 \mathrm{~mm}$ in diameter, enlarging to a pileus in the immature fruit; the ovary grown to the perianth tube, style branches about 0,6 mm long. Fruit ellipsoid, about $12 \mathrm{~mm}$ long, $7 \mathrm{~mm}$ wide, the fruiting pedicels to $8 \mathrm{~mm}$ long and about $2 \mathrm{~mm}$ in diameter.

Flowering from October to November.

Distribution: Only two collections known from Bolivia (map 6), from 300-500 $\mathrm{m}$ altitude.

Bolivia: BenI: Rurrenabaque, Cardenas 1757 q (NY); Ixiamas, R. S. Williams 412 우 (NY).

The thickened perianth tube forms a conspicuous cap on the young fruit in this species. The cap however does not persist and the mature fruit becomes ellipsoid. $S$. pileata is closely related to $S$. briquetii as evidenced by the pistillate flowers but the larger fruit and broadly elliptic leaves readily distinguish the former.

6. Sorocea hirtella Mildbraed, Notizbl. Bot. Gart. Berlin 10: 183. 1927; Macbride, Field Mus. Bot. 13 (2): 311.1937.

Type: Tessmann $4016 \precsim$, from mouth of Río Santiago, Upper Marañón, Peru (B).

Heterotypic synonyms: Sorocea ulei Warburg, nomen nudum, Bot. Jahrb. 40: 141. 1907; Macbride, Field Mus. Bot. 13 (2): 313. 1937.

Sorocea steinbachii Mildbraed, nomen nudum, Macbride, Field Mus. Bot. 13 (2): 312, 313. 1937. Plate III: Fig. 1, 2, 3, 4

Leaves obovate or elliptic, 7-20 cm long, with 7-12 pairs of lateral veins, arching upward near the entire margin; petioles 5-22 $\mathrm{mm}$ long. Staminate inflorescences spicate with numerous, somewhat distant sessile flowers; stamens bent outward, anthers emarginate. Pistillate inflorescences spicate with 15 to many flowers, about $2 \mathrm{~mm}$ in diameter with a collar at the apex, formed by the perianth tube. Fruiting pedicels to $7 \mathrm{~mm}$ long. 


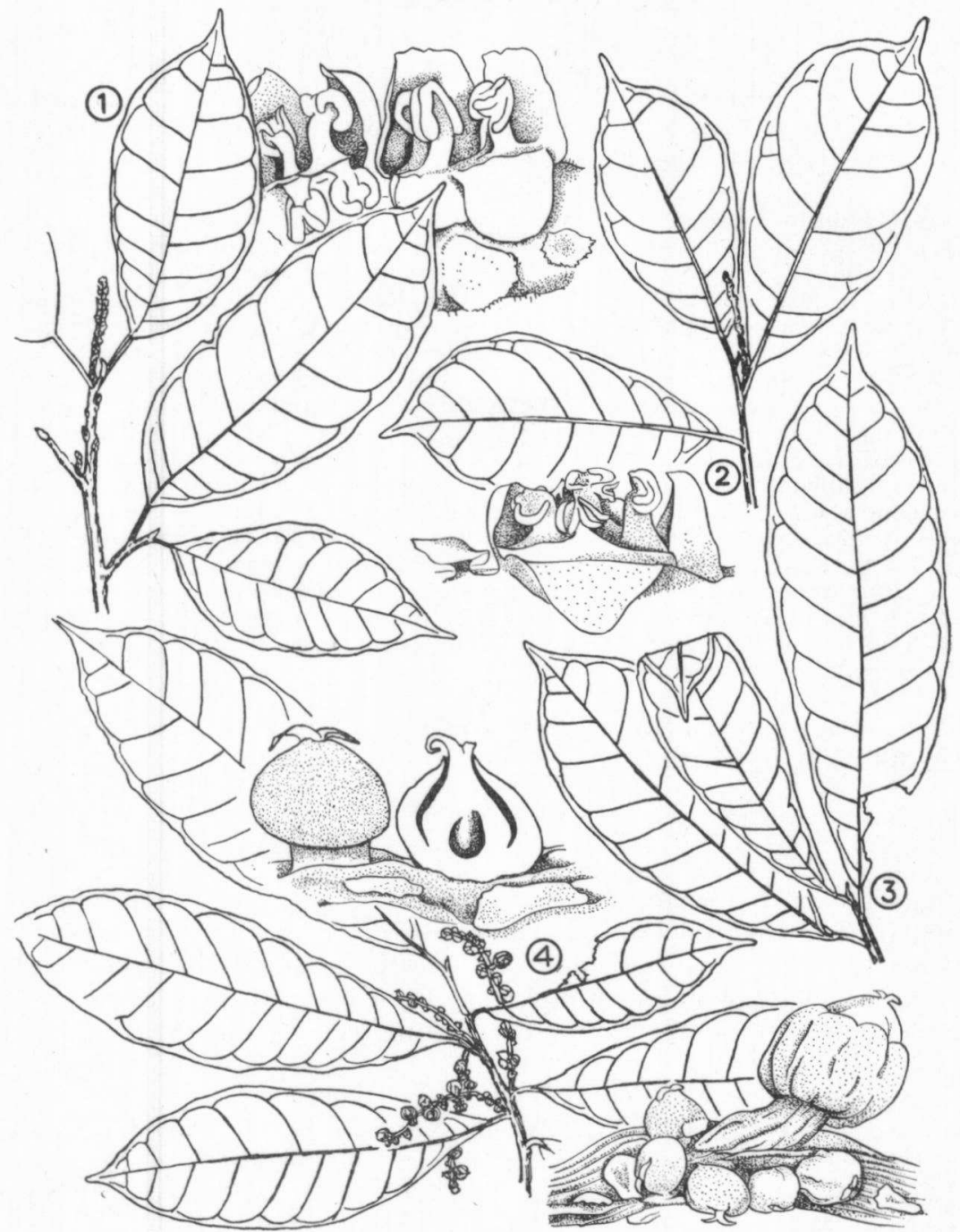

Plate III. Sorocea hirtella: from Tessmann 4016 (fig. 1), Ducke 949 (fig. 2), Krukoff 5785 (fig. 3), and Steinbach 7356 bis (fig. 4).

Shrubs or trees to $20 \mathrm{~m}$ tall; leafy branchlets $1,2-3,5 \mathrm{~mm}$ in diameter, minutely puberulent or glabrescent, the lenticels usually inconspicuous. Leaf blades broadly or sometimes narrowly obovate or elliptic, 7-19 $(-26) \mathrm{cm}$ long, $2,5-6,5(-8,0) \mathrm{cm}$ broad, subacuminate to abruptly acuminate, acute to obtuse at the base, chartaceous to pergamentaceous, smooth and glabrous above, hirtellous to glabrescent beneath, more or less bullate, the midvein plane or impressed above, prominent below with 7-12 pairs of ascending secondary veins arching upward near the entire or slightly undulate to somewhat repand toothed margin; petiole 5-22 mm long, 1,1-2,2 $\mathrm{mm}$ in diameter, sparsely and minutely puberulent. Stipules caducous, cuneate, 4-7 mm long, their scars conspicuous on younger branchlets. Staminate inflorescences: spicate, paired or solitary in the axils of leaves or fallen leaves, $3,2-9,5 \mathrm{~cm}$ long, the peduncle $0,5-3,5 \mathrm{~mm}$ long, the rachis with numerous sub- 
orbicular or cuneate, peltate or basally attached bracts $0,7-2,4 \mathrm{~mm}$ broad; flowers numerous and usually somewhat distant, sessile, 1,4-2,8 $\mathrm{mm}$ long and $2,4-4,2 \mathrm{~mm}$ broad, the perianth parts broadly ovate and often sessile on the rachis, about 1,3-1,8 $\mathrm{mm}$ wide, obtuse at the apex and glabrescent; stamens bent outward at anthesis, the staminal filaments $0,4-1,3 \mathrm{~mm}$ long, about $0,4 \mathrm{~mm}$ in diameter, the anthers $0,5-0,9 \mathrm{~mm}$ long, emarginate. Pistillate inflorescences: spicate becoming racemose, paired or solitary in the axils of leaves or fallen leaves, 1,5-6,5 cm long, the peduncle $0,5-4,5 \mathrm{~mm}$ long, minutely puberulent or glabrescent, the rachis with numerous suborbicular or cuneate, peltate or basally attached bracts $1,2-2,4 \mathrm{~mm}$ broad, flowers 15 to many and crowded at first, subsessile but becoming pedicellate in fruit, the perianth tube indistinctly lobed at the apex, ovoid to globose, about $2 \mathrm{~mm}$ in diameter, usually glabrous, ovary free within the perianth tube, the style branches $0,5-0,8 \mathrm{~mm}$ long. Fruit globose about $6 \mathrm{~mm}$ in diameter, smooth and glabrous, becoming red, the fruiting pedicels to $7 \mathrm{~mm}$ long, about $1,5 \mathrm{~mm}$ in diameter.

Flowering in March and from August to October.

Distribution: Colombia to Peru, northern Bolivia and western Brazil (map 7). In moist forests and the mata de terra firma of the Amazon basin, from near sea level to $1000 \mathrm{~m}$ elevation.

Colombia: BoyACA: $130 \mathrm{mi}$. north of Bogotá, Lawrence 730 o (A, B, F, MO, S). CAquetA: Solano, $8 \mathrm{~km}$ SE of tres Esquinas, E. L., \& R. R. Little 9572 (US), 9651 oै (US).

PERU: LORETo: near mouth of Río Tigre, Río Marañón, Killip \& Smith 27531 o (F, US); mouth of Río Santiago, Tessmann 4016 ơ (B, F, NY); Soledad, Tessmann 5251 o (F, NY).

Bolrvia: LA Paz: San Carlos, Mapiri Region, Buchtien 1658 오 (B, US); Tuiri, Prov. Larecaja, Krukoff 10819 ơ (F, LIL, MO, S, U), 10932 (F, LIL, MO, S, U). Santa Cruz: Monte de Buenavista, Sará, Steinbach 1425 ơ (B), 2939 đั (B); Río Surutŭ, Buenavista, Sará, Steinbach 3042 đo (B, LIL,) 3515 \% (B, LIL); bosques de Buenavista, Steinbach 6548 đ (B, BM, F), 7272a $\delta^{\star}(\mathrm{B}, \mathrm{BM}, \mathrm{F}, \mathrm{MO}$, NY, S, U), 7356 \& (B, BM, F, GH, MO, NY, S, U).

BRAzIL: ACRE: near mouth of Rio Macauhan, Krukoff 5785 오 (A, BM, F, MO, NY, S, U). Amazonas: St. Antonio do Içá, Ducke 7655 q (MG, RB, U) ; near mouth of Rio Embira, Krukoff 4954 (F, S, U), 5084 (S); near Ega, Poeppig 2563 o (B, F, L); Juruá miry, Rio Juruá, Ule 5871 q \& ơ (B, F, L, RB). PARA: cult. in horto Mus. Belém, Ducke 949 ơ (F, NY).

This variable and wide ranging species is characterized by the stamens which are bent outward at anthesis and the generally entire obovate leaves. The Colombian collections resemble $S$. pubivena of Central America and may indicate a relationship with that species. The pistillate flowers and fruit, however, indicate an affinity to $S$. muriculata.

The important Bolivian collections of Steinbach were inscribed with a name in his honor by Mildbraed but this name has never been published. Macbride has used the specific epithet ulei based on a nomen nudum and also never validly published.

7. Sorocea opima Macbride, Field Mus. Bot. 11: 64. 1931; Macbride, Field Mus. Bot. 13 (2): 312.1937.

Type: L1. Williams 2337 \&, from Caballo-cocha, dept. Loreto, $\operatorname{Peru}(\mathrm{F})$. Plate IV: Fig. 1, 2, 3

Leaves elliptic oblong to obovate, 9-30 (-55) cm long, with 6-16 $(-22)$ pairs of lateral veins and a nearly straight marginal vein, 


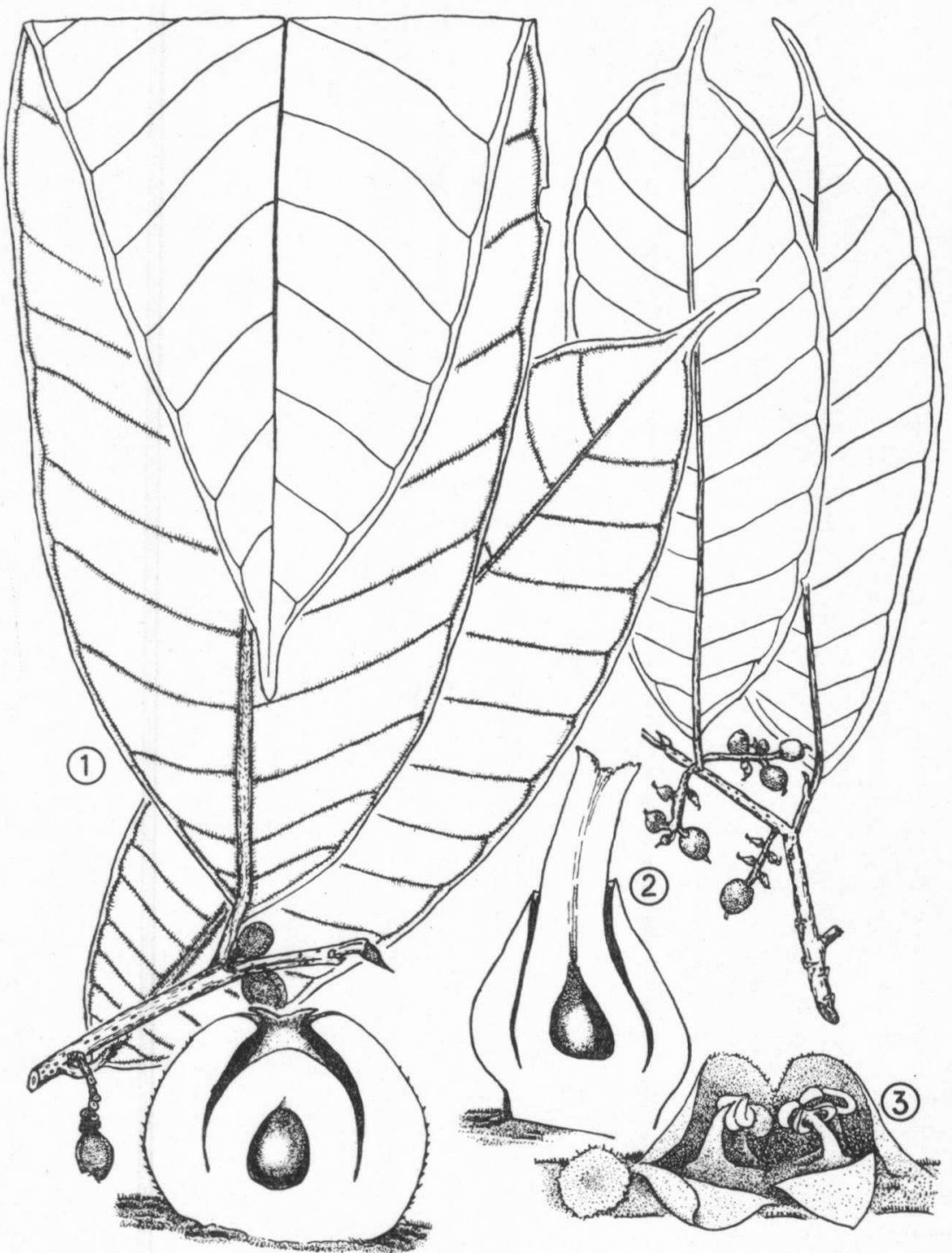

Plate IV. Sorocea opima: from Krukoff 8648 (fig. 1), Krukoff 8157 (fig. 2), and Klug 739 (fig. 3).

margin entire. Staminate inflorescences spicate with numerous and distant, sessile flowers; connective of the anthers prolonged beyond the thecae. Pistillate inflorescences with 4-15 subsessile flowers, usually over $3 \mathrm{~mm}$ long; style exserted about $1 \mathrm{~mm}$. Fruit globose to ovoid about $1 \mathrm{~mm}$ in diameter, fruiting pedicels to $6 \mathrm{~mm}$ long.

Shrubs or trees to $10 \mathrm{~m}$ tall; leafy branchlets thick, 1,8-5,0 $(-7) \mathrm{mm}$ in diameter, minutely puberulent and usually becoming glabrous, conspicuously lenticellate. 
Leaf blades elliptic oblong to obovate or occasionally oblanceolate, 10-30 (-55) cm long, 3,5-8,5 $(-20) \mathrm{cm}$ broad, often abruptly acuminate, narrowly acute to obtuse or slightly rounded at the base, chartaceous to pergamentaceous, glabrous above and glabrous to hirtellous beneath, more or less bullate, the midvein impressed above, prominent below with 7-15 (-22) pairs of ascending secondary veins joined near the entire or slightly undulate margin by a well defined, nearly straight marginal vein; petioles 8-15 (-21) $\mathrm{mm}$ long, 1-3 mm in diameter, sparsely puberulent. Stipules caducous, cuneate, 4,3-7,4 (-12) $\mathrm{mm}$ long, minutely puberulent, their scars conspicuous on the younger branchlets. Staminate inflorescences: spicate, paired or solitary in the axils of leaves or fallen leaves, $4,5-9,5 \mathrm{~cm}$ long, the peduncle $1,5-3,7 \mathrm{~mm}$ long, densely puberulent, the rachis with numerous suborbicular peltate bracts $0,7-1,6 \mathrm{~mm}$ broad; flowers numerous and distant, broadly sessile, $2,4-4,4 \mathrm{~mm}$ wide, the perianth parts arising from the rachis, broadly ovate, about $2 \mathrm{~mm}$ wide at the base, glabrous but minutely fimbriate along the margin, the stamens usually bent inwards at anthesis, staminal filaments $0,4-0,8$ $\mathrm{mm}$ long, the anthers $0,5-0,8 \mathrm{~mm}$ long, the connective often prolonged beyond the thecae. Pistillate inflorescences: racemose, paired or solitary in the axils of leaves or fallen leaves, $1,5-4,5 \mathrm{~cm}$ long, apparently elongating in fruit, the peduncle $1,5-8,5 \mathrm{~mm}$ long, densely puberulent, the rachis with numerous suborbicular peltate or basally attached bracts $0,8-1,3 \mathrm{~mm}$ broad; flowers 4-15 and distant along the rachis, subsessile but becoming pedicellate, the perianth tube indistinctly lobed at the apex, urceolate to narrowly ovoid, $2,5-3,5 \mathrm{~mm}$ in diameter, sparsely and minutely papillate-puberulent, the ovary free or partly grown to the perianth tube, the style exserted about $1 \mathrm{~mm}$ with thick style branches about $1 \mathrm{~mm}$ long. Fruit globose to ovoid, about $1 \mathrm{~cm}$ in diameter, glabrescent, the fruiting pedicels to $6 \mathrm{~mm}$ long and $1,8-2,8 \mathrm{~mm}$ in diameter.

Flowering from January to September.

Distribution: Peru and Brazil in the upper Amazon basin (map 8). In moist forests and on the mata de terra firma.

Peru: Loreto: near Iquitos, Klug 739 o (F), Kuhlmann 1517 o (RB); Caballococha on the Amazon R., Li. Williams 2092 o (F), 2357 i (F).

BraziL: Amazonas: near mouth of Rio Uaupés, Baldwin 3560 o (US); Foz do Caiary, Rio Negro, Fróes 22148 \& (U); Pôrto Velho, Madeira, Kuhlmann 401 ơ (RB); São Paulo de Olivença, near Palmares, Krukoff 8157 우 (BM, F, MICH, MO, S); basin of Creek Belém, Krukoff 8648 \& (A, BM, F, MO, NY, U); Tapurucuara, Rio Negro, Murça Pires 248 o (NY, US); Jupatí, Rio Negro, Murça Pires 338 ơ (NY, US), 343 o (NY, US); Vaupés, Rio Negro, Murça Pires 518 q (NY, US); Serra de São Gabriel, Murça Pires 556 o (NY).

The collection of Krukoff, number 8648 우, is rather peculiar, distinguished in the sessile fruit and the very large hispidulous leaves with 14-22 pairs of secondary veins from the typical $S$. opima. At first it was thought to be a new species, but in the absence of sufficient material and the similarity to $S$. opima it seems better to place it with the latter.

8. Sorocea cufodonti $W$. Burger nov. spec.

Type: Cufodontis 200 ơ, from Puerto Jiménez, Puntarenas, Costa Rica (F).

Plate V

Folia elliptica ad oblongo-elliptica, acuminata, glabra, basi saepe inaequalia, integra, nervis secundariis 8-14-jugis. Inflorescentia mascula spicata; flores late sessiles; tepala sparse puberula, antherae filamenta fere aequantes, connectivis breviter exsertis; pistillodium stylo inflexo. 
448

W. C. BURGER, J. LANJOUW AND J. O. WESSELS BoER

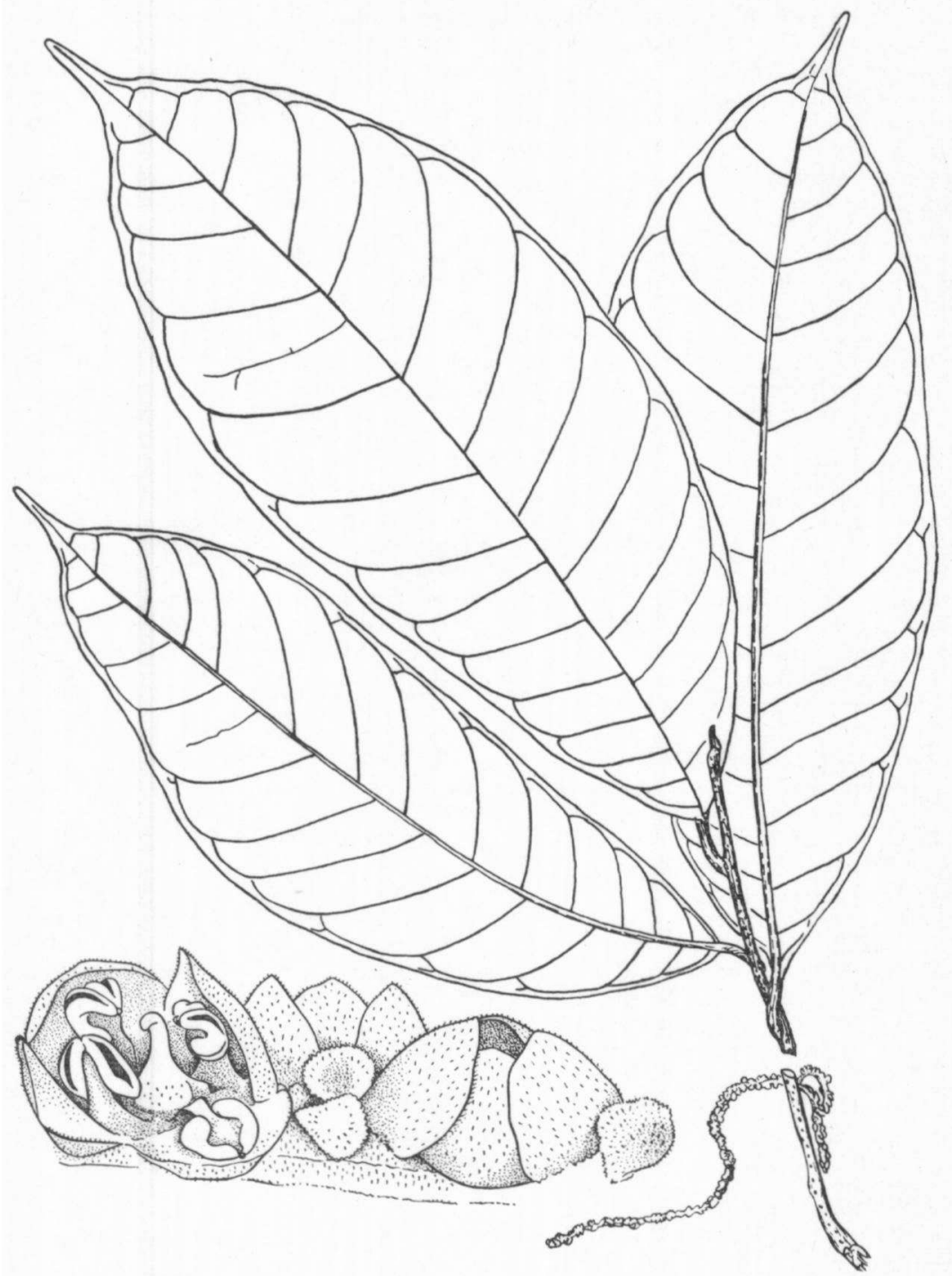

Plate V. Sorocea cufodonti: from Cufodontis 200.

Trees; leafy branchlets $2,4 \mathrm{~mm}$ in diameter, glabrescent, the lenticel conspicuous Leaf blades narrowly elliptic to oblong-elliptic, $13-30 \mathrm{~cm}$ long, $8-11 \mathrm{~cm}$ broad, abruptly acuminate, acute or obtuse at the base, usually oblique, glabrous; the midvein slightly impressed above, prominent beneath with 8-14 pairs of ascending secondary veins arching upward near the entire margin; petioles $12-20 \mathrm{~mm}$ long, $2-4 \mathrm{~mm}$ in diameter, glabrous. Stipule caducous, cuneate, about $5 \mathrm{~mm}$ long, their scars rather inconspicuous. Staminate inflorescences: spicate, paired in the axils of leaves or fallen leaves, $2-10 \mathrm{~cm}$ long, the peduncle about $4 \mathrm{~mm}$ long, minutely puberulent, the rachis with numerous suborbicular peltate or basally attached bracts, 0,9-1,5 mm broad; flowers numerous and usually somewhat distant, 
sessile, 1,8-3,5 mm wide, perianth parts broadly oval, about $2 \mathrm{~mm}$ long, obtuse at the apex, minutely puberulent; the staminal filaments about $0,7 \mathrm{~mm}$ long; anthers $0,7-1,0 \mathrm{~mm}$ long, the connective slightly prolonged beyond the thecae, a prominent ovoid pistillode with a short twisted style present in the centre of the flower. Pistillate inflorescences and fruits unknown.

Flowering in April.

Distribution: Costa Rica (map 9). At forest edge near sea level.

Costa rica: Puntarenas: ca. Puerta Jiménez, peninsular Osa at Golfo Dulce, Cufodontis 200 đै (F), Brenez 12207 (F).

The broadly sessile staminate flowers with a prominent ovoid pistillode that terminates in a short bent or twisted style distinguish this species. The glabrous leaves resemble $S$. pubivena in form and size and probably indicate some relationship.

9. Sorocea pubivena Hemsley, Biol. Centr. Am. Bot. 3: 150. 1883; Standley \& Steyermark, Fieldiana (Bot.) 24 (4): 55. 1946; Burger, Ann. Missouri Bot. Gard. 47: 122. 1960.

Type: Friedrichsthal s.n. ㅇ, from Guatemala? (K).

Heterotypic synonyms: Trophis macrostachya Donnell Smith, Bot. Gaz. 40: 10. 1905; Standley, Field Mus. Bot. 18: 392. 1937. Type: Tonduz 8124 ㅇ (n 12802 herb nat. Cost.), from las Vueltas, Tucurrique, Costa Rica (US).

Clarisia mollis Standley, Ann. Missouri Bot. Gard. 30: 85. 1943. Type: von Wedel 1090 ô, from vicinity of Chiriquí Lagoon, Panamá (F).

Plate VI: Fig. 3, 4

Leaves broadly elliptic to oblong, caudate acuminate, usually hirtellous beneath, 10-30 cm long; margin entire to bluntly serrate. Staminate inflorescences spicate, densely hirtellous, with numerous sessile flowers; connective prolonged beyond the thecae. Pistillate racemes densely hirtellous, rather short, with numerous subsessile flowers, becoming distant in fruit. Fruit subglobose, about $1 \mathrm{~cm}$ in diameter; fruiting pedicels usually stout, to $13 \mathrm{~mm}$ long and to $2,8 \mathrm{~mm}$ in diameter.

Shrubs or trees to $20 \mathrm{~m}$ tall; leafy branchlets $1,5-4,3 \mathrm{~mm}$ in diameter, densely hirtellous, becoming glabrous, the lenticels conspicuous. Leaf blades narrowly to broadly elliptic or oblong, $10-28 \mathrm{~cm}$ long, $4,2-10,5 \mathrm{~cm}$ broad, acuminate, obtuse to acute at the base, membranaceous to chartaceous, glabrous above, hirtellous or glabrescent beneath, the midvein slightly impressed above, prominent beneath with 7-12 pairs of ascending secondary veins arching upward near the entire to bluntly serrate margin; petioles 7-23 $\mathrm{mm}$ long, 1,2-3,3 $\mathrm{mm}$ in diameter, densely and minutely puberulent, becoming glabrous. Stipules caducous, cuneate, $4-8 \mathrm{~mm}$ long, their scars conspicuous on the younger branchlets. Staminate inflorescences: spicate, paired or solitary in the axils of leaves or fallen leaves, 4-11 cm long, the peduncle 2,1-5,5 mm long, densely hirtellous, the rachis with numerous suborbicular peltate or basally attached bracts $0,7-1,4 \mathrm{~mm}$ broad; flowers numerous and not usually crowded, sessile, 1,8-3,5 mm wide, perianth parts subequal and broadly oval, about $1,8 \mathrm{~mm}$ long, obtuse at the apex, minutely papillate-puberulent, the staminal filaments $1,1-1,6 \mathrm{~mm}$ long, anthers $0,6-0,8 \mathrm{~mm}$ long, the connective usually prolonged into a gland-like projection. Pistillate inflorescences: spicate or racemose, solitary or paired in the axils of leaves or fallen leaves, 1,3-6,5 cm long and elongating in fruit, the peduncle $1,2-4,3 \mathrm{~mm}$ long and densely hirtellous, 
the rachis with numerous suborbicular peltate or basally attached bracts $0,7-1,5$ $\mathrm{mm}$ broad; flowers numerous and crowded, often becoming distant in fruit, subsessile or very short pedicellate, the pedicels about $0,5 \mathrm{~mm}$ long, the perianth tube indistinctly lobed at the apex, ovoid or cylindrical, becoming thickened above, about $2 \mathrm{~mm}$ in diameter, minutely papillate-puberulent, ovary partly grown to the perianth tube or rarely free at anthesis and minutely puberulent, the style branches $0,6-1,0 \mathrm{~mm}$ long. Fruit globose, about $1 \mathrm{~cm}$ in diameter, glabrescent, occasionally subsessile but usually on stout pedicels to $13 \mathrm{~mm}$ long and $1,6-2,8 \mathrm{~mm}$ in diameter.

Flowering from October to July.

Distribution: Costa Rica to Panama (map 10). In moist forests from sea level to $800 \mathrm{~m}$ elevation.

Costa rica: Cartago: Tuis, near Turrialba, Pittier 11266 q (F, MICH, US), Tonduz 11357 \& (US); Zhorquin, Talamanca, Tonduz 8563 + (US); Río de las Vueltas, Tucurrique, Tonduz 8124 o (B, US), $12844 \sigma^{\circ}$ (GH, K, NY). Puntarenas: forests of Palmar, Tonduz 6751 ơ (US). Limon: Río St. Clara, near Guápiles, Los Diamantes, Holm \& Iltis 389 ơ (F, US, U); Río Blanco, St. Clara, Pittier $13453 \delta^{\star}$ (US); Goldengrove, Río Reventazón, Shank \& Molina $4384 \delta$ o (US).

Panama: Bocas del Toro: Changuinola Valley, Almirante Region, Cooper \& Slater 28 (US, YU), 107 (F, US, YU); vicinity of Chiriquí Lagoon, von Wedel 1090 of (F, MO). Chiriqut: Cerro Galera Chorcha, near Gualaca, Allen 5059 q (BM, MO); Progreso, Cooper \& Slater 174 \& (F, NY, US, YU).

Standley and Steyermark comment that probably Friedrichsthal's type collection was not collected in Guatemala, it really cames from Nicaragua or Costa Rica.

The characters used to distinguish $S$. pubivena from $S$. trophoides appear least trustworthy at higher elevations (ca. $700 \mathrm{~m}$ ) where perhaps hybridisation may be taking place.

10. Sorocea trophoides W. Burger nov. spec.

Type: Austin Smith 141 ㅇ, from Alfaro Ruiz, Zarcero, Costa Rica (MO, isotype in $\mathrm{F}, \mathrm{U}$ ).

Plate VI: Fig. 1, 2

Folia elliptica ad oblongo-elliptica, longe acuminata, serrata, chartacea, supra glabra, infra sparse puberula vel glabra, nervis secundariis 6-7-jugis. Inflorescentia mascula spicata, sparse puberula; flores sessiles; tepala glabra; filamenta antheris plus quam duplo longiora; connectivum breviter exsertum. Inflorescentia feminea racemosa, statu fructifero valde elongata; pedicelli sub fructibus ad $18 \mathrm{~mm}$ longi.

Trees to $12 \mathrm{~m}$ tall; leafy branchlets $08-2,5 \mathrm{~mm}$ in diameter minutely appressed puberulent, becoming glabrous. Leaf blades elliptic to elliptic-oblong, $7-12(-17)$ $\mathrm{cm}$ long, 2-6 cm broad, long acuminate, the acumen about $2 \mathrm{~cm}$ long, obtuse to acute at the base, chartaceous, glabrous above and minutely puberulent or glabrous beneath, the midvein slightly impressed above, prominent beneath with 6-10 pairs of ascending secondary veins arching upward near the serrate margin; petioles 5-14 (-22) $\mathrm{mm}$ long, about $1,4 \mathrm{~mm}$ in diameter. Stipules caducous, narrowly cuneate, 3-7 mm long, their scars inconspicuous. Staminate inflorescences: spicate, paired or solitary in the axils of leaves or fallen leaves, $2,5-6,5 \mathrm{~cm}$ long, the peduncle about $3 \mathrm{~mm}$ long, minutely puberulent, the rachis with numerous suborbicular peltate or basally attached bracts, $0,7-1,8 \mathrm{~mm}$ broad; flowers numerous and crowded, sessile, perianth parts oval, about $2 \mathrm{~mm}$ long, glabrous; the staminal filaments 1,8-2,6 mm long, anthers $0,7-1,1 \mathrm{~mm}$ long, the connective prolonged into a short projection, the apex of the thecae often turned downward. Pistillate 
THE GENUS SOROCEA ST. HIL. (MORAC.)

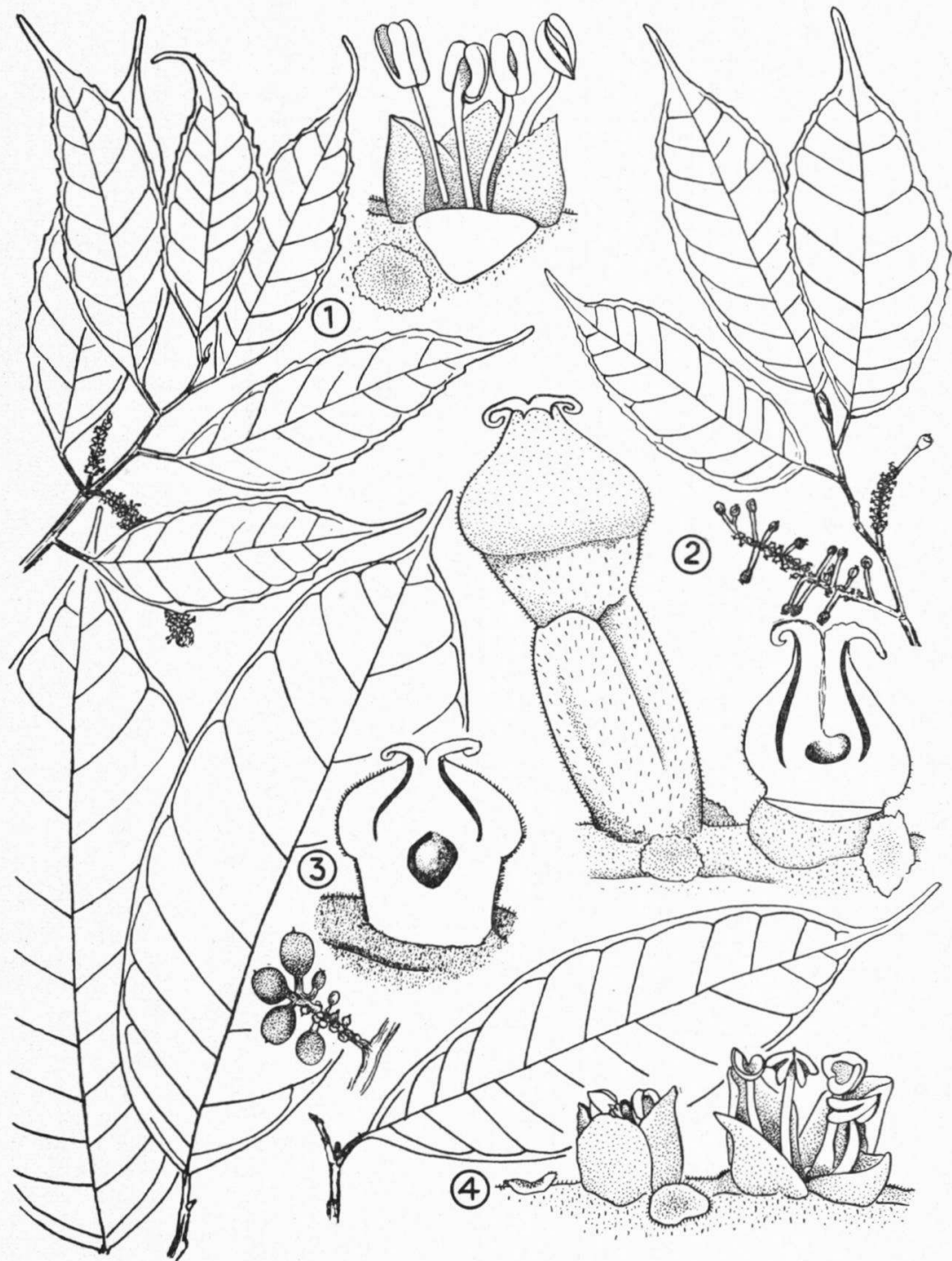

Plate VI. Sorocea trophoides: from Austin Smith 4227 (fig. 1), and Austin Smith A391 (fig. 2). Sorocea pubivena: from Allen 5059 (fig. 3), and Tonduz 6751 (fig. 4).

inflorescences: racemose, solitary or paired in the axils of leaves, 2-4 cm long and elongating to $10 \mathrm{~cm}$ in fruit, the peduncle $3-8 \mathrm{~mm}$ long, puberulent, the rachis with numerous suborbicular and usually peltate bracts. Flowers 12 to many, the perianth urceolate, about $2 \mathrm{~mm}$ in diameter glabrous, ovary free within the perianth tube at anthesis, the style branches $0,5-1,2 \mathrm{~mm}$ in diameter.

Flowering from April to August.

Distribution: Costa Rica to Peru (map 11). In moist forests at altitudes between 1000 and $2000 \mathrm{~m}$. 
Costa Rica: Alajurla: La Palma de San Ramón, Brenez 4332 오 (F), 6235 of (F), 6364 o (F); Zarcero, Alfaro Ruiz, Austin Smith 141 o (F, MO), 2720 to (F), 4227 ơ (F), A391 of (F), NY802 of (F, NY), P 2313 ㅇ (A); Lagunia, Alfaro Ruiz, Austin Smith 2851 ( $(\mathrm{F})$.

Panama: Chiriquf: El Boquete, Pittier 3045 o (BM, NY, US).

Colombia: Cundinamarca: San Francisco, Vereda Torriba, Garcia Barriga 10988 o (F, LIL, US). VAlle del CAUCA: La Cumbre, quebrada La Ventura, Uribe 1221 o (US).

PERU: HuÁnuCo: confluence of Río Cayumba with Huallaga, Mexia 8260 o (BM, GH, F, MO, S, U). SAN MARTín: Zepelacio, near Moyobamba, Klug 3566 of (A, F, MO, NY, U).

This species has been consistently filed under Trophis, probably because the anthers are often inwardly inclined at anthesis. The important generic character of straight or inflexed stamens, however, refers only to aestivation.

This species may prove difficult to separate from $S$. pubivena at lower elevations $(700-1000 \mathrm{~m})$ in Costa Rica, where perhaps some hybridisation occurs.

11. Sorocea sarcocarpa Lanjouw \& W. Boer nov. spec.

Type: Little 6375 ㅇ, from $4 \mathrm{~km}$ west of Borbón, Esmeraldas, Ecuador (F).

Plate VII: Fig. 3

Folia obovata, abrupte caudato-acuminata, ad basim angustata, chartacea, supra glabra, infra sparse hispidula vel glabra, obtuse serrata, nervis secundariis 7-13-jugis. Inflorescentia mascula spicata; flores late sessiles; antherae emarginatae. Inflorescentia feminea racemosa; flores pedicellati, inter se libera. Drupa globosa, diametro ca. $1 \mathrm{~cm}$, atro-coerulea, carnosa, pedicello ca. $1 \mathrm{~cm}$ longo insidens.

Small trees to $15 \mathrm{~m}$ tall; leafy branchlets $0,9-3,7 \mathrm{~mm}$ in diameter, more or less hispidulous, glabrescent, the lenticels inconspicuous. Leaf blades obovate, $7-23 \mathrm{~cm}$ long and 3,5-10,6 cm broad, abruptly caudate-acuminate, narrowed towards the base, membranaceous to chartaceous, glabrous above, sparsely hispidulous to glabrous beneath, the midvein slightly impressed above, prominent below with 7-13 pairs of ascending secondary veins arching upward near the repandly serrate margin and forming an arcuate marginal vein; petiole $2-17 \mathrm{~mm}$ long. 0,9-1,8 $\mathrm{mm}$ in diameter, densely to sparsely hispidulous. Stipules caducous, narrowly cuneate, 2-5 $\mathrm{mm}$ long, their scars inconspicuous. Staminate inflorescences: spicate, paired or solitary in the axils of leaves or fallen leaves, $2,9-8,3 \mathrm{~cm}$ long, the peduncles about $3,5 \mathrm{~mm}$ long, minutely puberulent, the rachis with numerous suborbicular basally attached or peltate bracts, flowers numerous and distant, broadly sessile, perianth parts subequal, glabrous, about $1,8 \mathrm{~mm}$ long and $1,5 \mathrm{~mm}$ wide, the staminal filaments slender, about $1,3 \mathrm{~mm}$ long, anthers $0,6-0,9 \mathrm{~mm}$ long, emarginate. Pistillate inflorescences: racemose, paired or solitary in the axils of leaves or fallen leaves, $0,5-5,8 \mathrm{~cm}$ long, the peduncle $3,5-5,4 \mathrm{~mm}$ long, minutely hispidulous, the rachis with numerous orbicular basally attached bracts, 1-2 mm broad, flowers 5 to many and usually distant, pedicellate, the pedicels $0,4-1,8 \mathrm{~mm}$ long, the perianth minutely 4-lobed, obovoid to ovoid, 1,2-2,5 mm long and 1,3-2,0 mm in diameter, sparsely and minutely papillate-puberulent, the ovary free or basally grown to the perianth tube, style branches 1,2-1,5 $\mathrm{mm}$ long and recurved. Fruit globose, about $1 \mathrm{~cm}$ in diameter, dark blue to black, fleshy, glabrous, moulding on the tree. Fruiting pedicels red fleshy, 0,9-1,2 cm long, to 2,5 $\mathrm{mm}$ in diameter.

Flowering in February and March.

Distribution: Ecuador (map 12). In wet tropical forest from sea level to $800 \mathrm{~m}$ altitude. 
Ecuador: Bolfvar: Valle de Limón, Solis 6428 (F); Esmeraldas: $4 \mathrm{~km} \mathrm{~W}$. of Borbón, Little 6375 o (F). Guayas: near Balao, Eggers 14319 ơ (F), 14410 o \& o (B, L, US), 14640 ᄋ (A). Los Rios: $4 \mathrm{~km}$ W. of Pichilingue Little 6478 (F). Prchincra: trail from S. Domingo to Quininde, Little 6192 ㅇ (F).

This species shows a definite relationship with $S$. affinis but is in some respects distinctive: the broadly sessile staminate flowers (these occur rarely in $S$. affinis but never as broadly as here) the mature fruits blue-black and fleshy, the broader obovate, abruptly caudateacuminate leaves with a repandly serrate margin.

There is a considerable disjunction between the distribution areas of the two species but more intense collecting will perhaps fill in this gap.

12. Sorocea affinis Hemsley, Biol. Centr. Am. Bot. 3: 150. 1883; ibid. 5: t 79. 1886; Burger, Ann. Missouri Bot. Gard. 47: 121, f 38.1960 . (K).

Type: Hayes 684 \&, from Rio Grande near Paraiso Station, Panamá Plate VII: Fig. 1, 2

Leaves elliptic to elliptic-oblong, acuminate, acute at the base, margin entire to bluntly serrate, staminate inflorescences racemose with numerous and distant pedicellate flowers; staminal filaments slender, the connective prolonged beyond the thecae. Pistillate inflorescences minutely puberulent, the perianth forming a pileus at the apex of the developing fruit. Fruit densely short pubescent, becoming red; fruiting pedicels 2-10 $\mathrm{mm}$ long.

Shrubs or trees to $15 \mathrm{~m}$ tall, usually $4-7 \mathrm{~m}$; leafy branchlets $0,9-2,8 \mathrm{~mm}$ in diameter, minutely puberulent, glabrescent, the lenticels often conspicuous. Leaf blades narrowly elliptic to elliptic-oblong, 8-18 cm long, 2,5-7,2 cm broad, acuminate to abruptly caudate-acuminate, acute or occasionally obtuse at the base, membranaceous to chartaceous, glabrous, the midvein slightly impressed above, prominent below with 7-12 pairs of ascending secondary veins arching upward near the entire or rarely bluntly serrate margin and often forming an arcuate marginal vein; petiole $3-11 \mathrm{~mm}$ long, $0,6-1,8 \mathrm{~mm}$ in diameter, sparsely puberulent and soon glabrescent. Stipules caducous, narrowly cuneate, 2-5 mm long, their scars inconspicuous. Staminate inflorescences: racemose or occasionally spicate, paired or solitary in the axils of leaves or fallen leaves, 1,8-7,5 cm long, the peduncles $1,2-4,8 \mathrm{~mm}$ long, minutely puberulent, the rachis with numerous suborbicular peltate bracts $0,6-1,9 \mathrm{~mm}$ broad, usually with prominent stipes about $0,5 \mathrm{~mm}$ long; flowers numerous and distant, pedicellate or rarely sessile, the pedicels $0,3-1,7$ $\mathrm{mm}$ long, perianth parts subequal, about $2 \mathrm{~mm}$ long and $1,5 \mathrm{~mm}$ wide, sparsely and minutely puberulent, the staminal filaments slender, about $1,5 \mathrm{~mm}$ long, anthers $0,5-0,8 \mathrm{~mm}$ long, the connective prolonged beyond the thecae into a glandlike projection. Pistillate inflorescences: racemose, paired or solitary in the axils of leaves or fallen leaves, $1,3-5,8 \mathrm{~cm}$ long, the peduncle $1,2-3,8 \mathrm{~mm}$ long, minutely puberulent, the rachis with numerous suborbicular peltate bracts $0,5-1,4 \mathrm{~mm}$ broad, usually with prominent stipes; flowers 10 to many and usually distant, pedicellate, the pedicels $0,4-2,0 \mathrm{~mm}$ long, the perianth tube indistinctly lobed at the apex, ovoid or globose at first, then thickened above and forming a pileus at the apex of the developing fruit, about $2 \mathrm{~mm}$ in diameter, sparsely and minutely papillate-puberulent below and glabrous on the upper half, the ovary grown to the perianth tube, style branches $0,6-1,2 \mathrm{~mm}$ long and recurved. Fruit globose, about $8 \mathrm{~mm}$ in diameter, densely and minutely pubescent, becoming red, the pink fruiting pedicels $2-10 \mathrm{~mm}$ long and $0,7-1,7 \mathrm{~mm}$ in diameter.

Flowering throughout the year. 


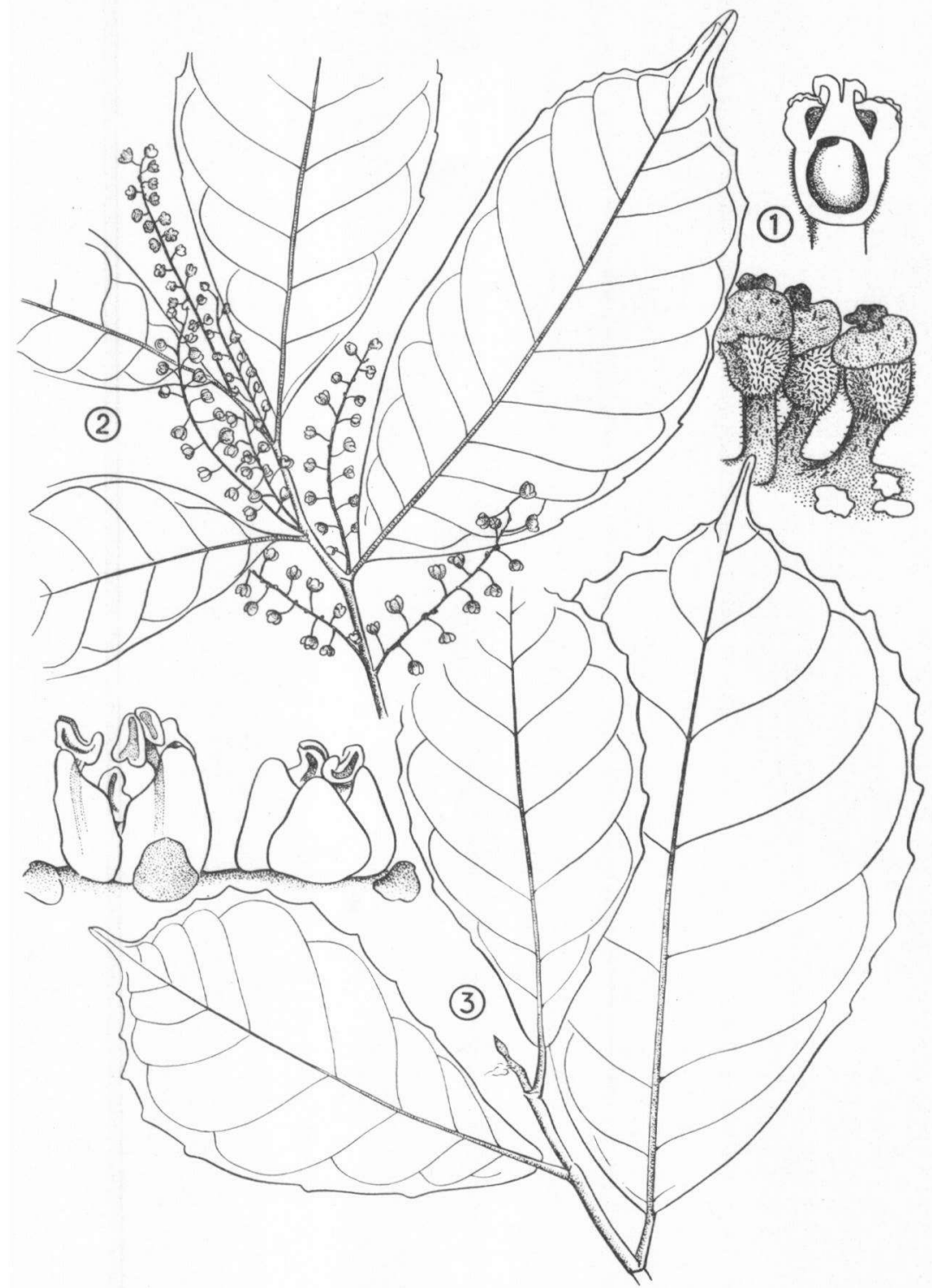

Plate VII. Sorocea affinis: from Pittier 4034 (fig. 1), and Pittier 3856 (fig. 2) Sorocea sarcocarpa: from Eggers 14410 (fig. 3).

Distribution: Guatemala to Panama (map 13). In moist swampy forests from sea level to $150 \mathrm{~m}$ altitude.

Guatemala: Izabal:Cerro San Gil, along Río Tameja, Steyermark 41801 우 (F).

Nicaragua: Zelaya: bosque lluvioso de montana de Esquipulas y Alemán, Shank \& Molina 4827 ○ (US). 
Costa Rica: Puntarenas: between Río Espinas and Palmar Sur de Osa, Allen 5492 ơ (US).

PANAMA: Bocas del Toro: Flat Rock, Almirante region Cooper 554 o (C, F, US, YU); Water Valley, von Wedel 598 A + (MO), 961 \& (MO); vicinity of Chiriquí Lagoon, von Wedel 1103 के (MO, US), 1390 के (MO, US), 1715 ơ (MO, US). CANal zoNe: Barro Colorado Island, Aviles 13 क (F), 26 \% (F), 52 \% (F), L. H. \& E. Z. Bailey 538 q (F), Bangham 558 q (F, US), Kenoyer 324 \& \& ô (US), Seibert 566 o (MO), Standley 40797 o (US), 41053 o (US), Starry 84 + $(\mathrm{F}), 314$ o (F), Stevens 12 o (US), Woodworth \& Vestal 323 \& (F); near Gatún, Johnston 1582 o (MO), 1693 o (MO); Trinidad river, Pittier 4034 o (BM, US); vicinity of las Cruces, Seibert 576 (MO); Gamboa, Standley 28412 ( 9 (US); banks of Quebrada Melgada, Steyermark 17494 우 (MO, S). Coclé: El Valle, Seibert 464 o (MO). Colón: Loma de la Gloria, near Fato, Pittier 3856 o (BM, F, US); vicinity of Palenque, Pittier 4123 a (BM, US). DARIÉn: Ensenada Guayabo between Punta Guayabo Grande and Punta Guayabo Chiquita, Stern \& Chambers 180 o (MO); Trail, Paya to Pucra, Stern et al. 233 ㅇ (MO). Panamá: near Arraiján, Woodson, Allen \& Seibert 1383 ơ (F, MO). Without locality: Hayes 684 ㅇ (K, P).

13. Sorocea racemosa Gaudichaud, Bot. Voy. Bonite t 72. 1844; Trécul, Ann. Sc. Nat. Paris (Bot.), sér 3.8: 145, t 6, f 182, 184. 1847; Miquel in Martius, Fl. Bras. 4 (1): 213. 1853.

Type: Gaudichaud 1090 bis

Heterotypic synonyms: Sorocea macrophylla Gaudichaud, Bot. Voy. Bonite t 73. 1844; Miquel in Martius, Fl. Bras. 4 (1): 214.1853. Type: Gaudichaud 1090 ๙, from Rio de Janeiro, Brazil (P).

Sorocea grandis Warburg, nomen nudum, Bull. Soc. Bot. France 59: 644. 1912.

Plate VII, IX: Fig. 1

Leaves narrowly oblong to elliptic-oblong, acuminate, apex blunt or sharp-tipped, usually the oblique base rounded; margin entire to spinulose-dentate. Inflorescences flagelliform, racemose; staminate flowers pedicellate; anthers narrowed above, connective prolonged beyond the thecae; pistillate flowers reflexed on pendulous inflorescences. Fruit ellipsoid, about $1 \mathrm{~mm}$ in diameter; fruiting pedicels to $8 \mathrm{~mm}$ long, recurved.

Shrubs or small trees; leafy branchlets $1,2-3,4(-5,7) \mathrm{mm}$ in diameter, sparsely and minutely puberulent or glabrous, the lenticels inconspicuous. Leaf blades narrowly oblong to elliptic-oblong, 8-22 (-33) $\mathrm{cm}$ long, 2,7-7,5 $(-10,3) \mathrm{cm}$ wide, acuminate, the apex blunt or sharp-tipped, acute to obtuse and rounded at the base, often oblique, chartaceous to pergamentaceous, glabrous above, glabrescent below, the midvein slightly impressed above, prominent beneath with 7-15 pairs of ascending secondary veins arching upward near the entire to spinulose-dentate margin to form an arcuate marginal vein; petioles $3-10 \mathrm{~mm}$ long, 1,2-2,4 $\mathrm{mm}$ in diameter. Stipules frequently persistent, lanceolate 3,8-7,4 mm long, their scars conspicuous on the younger branchlets. Staminate inflorescences: racemose, solitary in the axils of leaves or fallen leaves, $4,5-15,0 \mathrm{~cm}$ long, the peduncles $2,3-6,7 \mathrm{~cm}$ long, the rachis with numerous suborbicular peltate or basally attached bracts 0,3-0,8 mm broad; flowers numerous and distant, about $3 \mathrm{~mm}$ wide, the pedicels 1,8-3,4 mm long, perianth parts subequal, broadly oval, about $2 \mathrm{~mm}$ long, glabrous, staminal filaments about $0,6 \mathrm{~mm}$ long, $0,3-0,4 \mathrm{~mm}$ in diameter, the anthers narrowed above, 1,1-1,4 mm long, the connective slightly expanded beyond the thecae. Pistillate inflorescences: racemose, solitary in the axils of leaves or fallen leaves, $7-28 \mathrm{~cm}$ long, the peduncles $2-15 \mathrm{~cm}$ long, sparsely and minutely puberulent, the rachis with numerous suborbicular peltate or basally attached bracts $0,3-0,8 \mathrm{~mm}$ broad; flowers numerous and distant, becoming reflexed on the pendulous inflorescences, the pedicels $1,2-2,7 \mathrm{~mm}$ long and elongating in fruit, perianth tube 


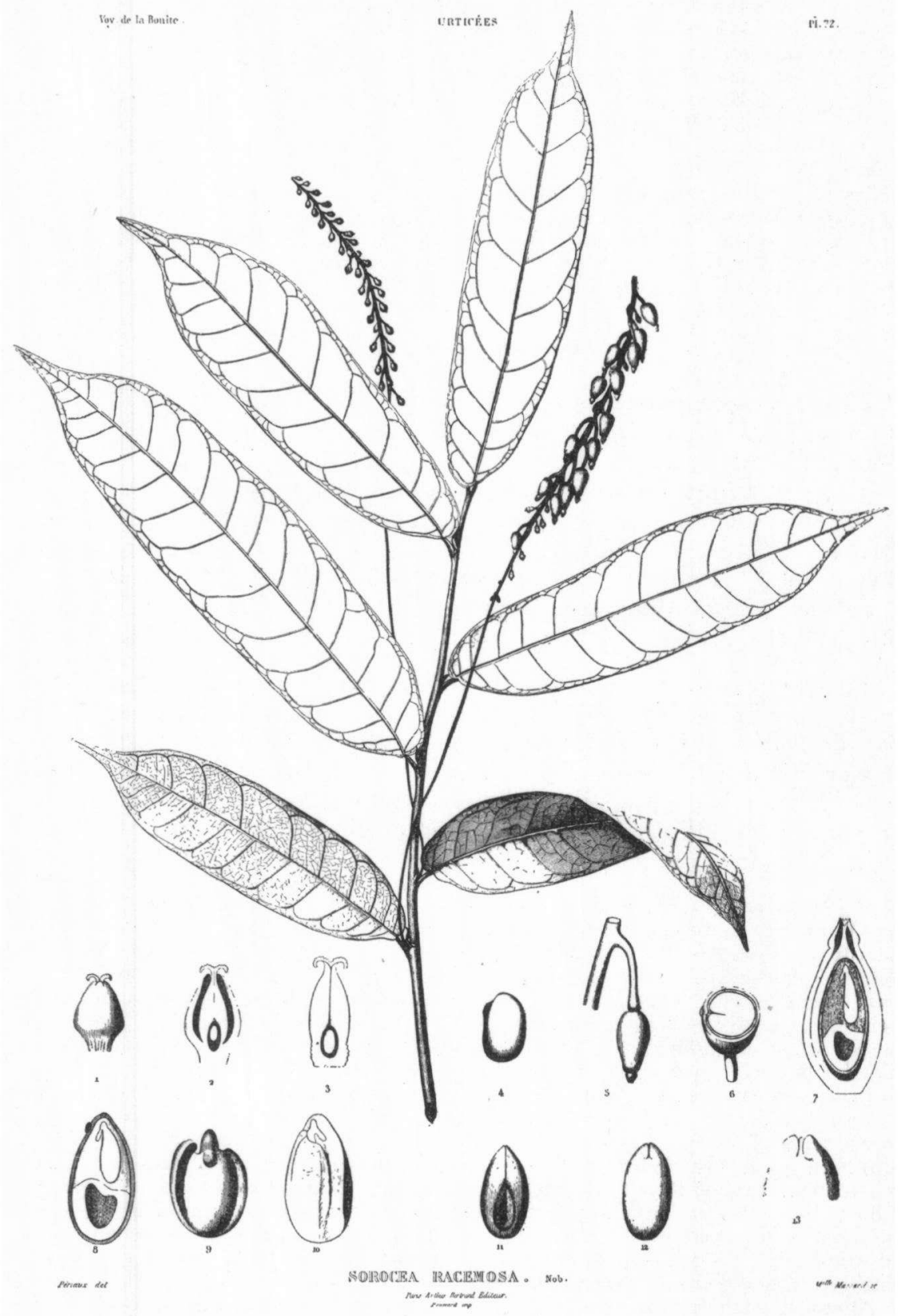

Plate VIII. Sorocea racemosa: from Gaudichaud Bot. Voy. Bonite, 1844, t. 72. 
indistinctly lobed at the apex, ellipsoid or becoming slightly thickened above, about $1,5 \mathrm{~mm}$ in diameter, minutely appressed puberulent below, and glabrous above, the ovary free or partly grown to the perianth tube and glabrous, style branches 0,5-0,9 mm long, recurved. Fruit ellipsoid, about $6 \mathrm{~mm}$ in diameter, minutely puberulent and smooth.

Flowering in January, February, and August.

Distribution: South-eastern Brazil (map 14). In moist forests.

Brazil: Espirito Santo: 'Cachoeira de Itapemirim, Brade 19746 q (RB). Rio DE JANEIRo: Serra da Carioca, Brade 12785 o (B, RB); Corcovado, Duarte 793 ㅇ \& $\delta(\mathbf{R B})$; Rio Santo Antonio, Glaziou 11567 \& \& $\delta(\mathbf{B}, \mathbf{C}, \mathbf{K}, \mathbf{P})$; ascent to the Paiñeron, Miers 3387 o \& $\delta$ (K, BM); Matas do Pae Richardo, Occhioni 245 of (RB), 246 of (RB). Without precise locality: Gaudichaud 1090 \& \& $\delta(\mathrm{B}, \mathrm{P})$, 1090 bis of (B, F, K), Glazinu 1137 ơ (BR, P), 11566 oै (B, C, P).

It would be expected that the specimen in Paris is the type, but Gaudichaud's plate is a female, the specimen in $\mathbf{P}$ is a male, in $\mathrm{K}$ a female, and in B branches of both male and female are present. The leaves on Gaudichaud's plate are entire; the leaves of the specimen in $\mathbf{P}$ are serrate in the upper part, the two branches in $\mathbf{B}$ are nearly entire; only the leaves in $\mathrm{K}$ are wholly entire and resemble closely the illustration in other respects. For these reasons we have to consider the specimen in $\mathrm{K}$ as the type.

$S$. racemosa is a very striking species with long-peduncled inflorescences and apparently apogeotropic pistillate flowers that become reflexed on the pendulous racemes. While distinct in many respects this species bears a resemblance to $S$. hilarii, which is sympatric with it.

14. Sorocea hilarii Gaudichaud, Bot. Voy. Bonite $t$ 71. 1844; Trécul, Ann. Sc. Nat. Paris (Bot.) sér 3.8: 145, t 6. 1847.

Type: Gaudichaud 1088 \&, from Rio de Janeiro, Brazil (P).

Homotypic synonym: Sorocea ilicifolia Miquel $\beta$ hilarii (Gaudichaud) Miquel in Martius, Fl. Bras. 4 (1): 213. 1853.

Heterotypic synonyms: Trophis hilariana Casaretto, Nov. Stirp. Bras. Dec. 19: 80. 1845; Sorocea hilariana (Gasaretto) Bureau in DC., Prodr. 17: 254. 1873. Type: Riedel s.n., from Corcovado, Brazil (not seen).

Sorocea uriamen Martius ex Miquel in Martius, Fl. Bras. 4 (1): 113. 1853. Type: Martius 1818 \&, from Bahia, Brazil (M).

\section{Plate IX: Fig. 2}

Leaves obovate-oblong to obovate-elliptic, abruptly acuminate, obtuse and oblique at the base, margin entire or serrate only in the distal half. Staminate racemes to $11 \mathrm{~cm}$ long; flowers pedicellate, distant, about $4 \mathrm{~mm}$ wide; staminate filaments short and thick, anthers emarginate. Pistillate racemes with short pedicellate, puberulous flowers; style branches short. Fruit ovoid, about $8 \mathrm{~mm}$ long, on thick red-fleshy pedicels.

Shrubs or small trees to $9 \mathrm{~m}$ tall; leafy branchlets $1,2-3,0 \mathrm{~mm}$ in diameter, very sparsely and minutely puberulent, soon becoming glabrous, conspicuously lenticellate. Leaf blades obovate-oblong to obovate-elliptic, abruptly acuminate, the 


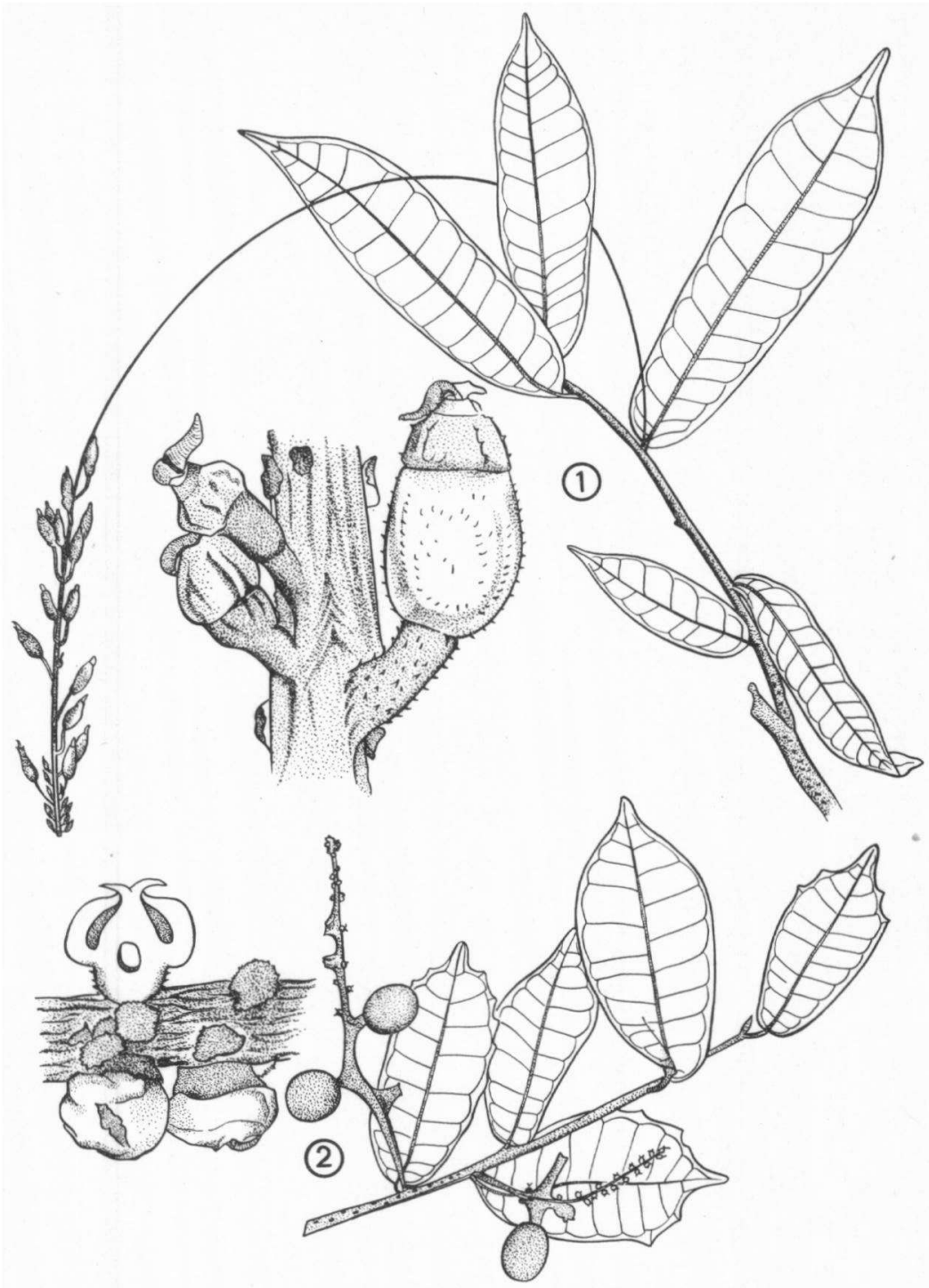

Plate IX. Sorocea racemosa: from Gaudichaud 1090 (fig. 1). Sorocea hilarii: from Schenk 1661 (fig. 2).

apex usually not sharp-tipped, narrowed towards the often obtuse and strongly oblique base, subcoriaceous, glabrous, often lustrous above, the midvein impressed above, prominent below with 8-11 pairs of ascending secondary veins arching upward near the entire or in the upper part remotely subserrate-dentate margin, petioles 2-12 $\mathrm{mm}$ long, sparsely and minutely puberulent. Stipules caducous, cuneate, 3-5 mm long. Staminate inflorescences: racemose, solitary or paired in the axils of leaves, $2,0-10,5 \mathrm{~cm}$ long, the peduncles about $5 \mathrm{~mm}$ long, minutely puberulous, the rachis with numerous oblong or suborbicular basally attached or peltate bracts, $0,7-1,6 \mathrm{~mm}$ broad, flowers numerous and distant, about $4 \mathrm{~mm}$ wide, 
the pedicels to $3 \mathrm{~mm}$ long, perianth parts subequal, broadly oval, about $2 \mathrm{~mm}$ long, sparsely and minutely puberulent, staminal filaments $0,4-0,8 \mathrm{~mm}$ long, $0,3-0,4 \mathrm{~mm}$ in diameter, the anthers about $0,8 \mathrm{~mm}$ long, emarginate. Pistillate inflorescences: racemose, solitary or paired in the axils of leaves, $46 \mathrm{~cm}$ long, elongating to $12 \mathrm{~cm}$ in fruit, the peduncles $4-8 \mathrm{~mm}$ long, puberulent, the rachis with numerous suborbicular, peltate or basally attached bracts, $0,5-1,7 \mathrm{~mm}$ broad, flowers numerous, distant along the rachis, short pedicellate to subsessile, the pedicels elongating in fruit to about $7 \mathrm{~mm}$, perianth tube globose, $1,3-2,0 \mathrm{~mm}$ in diameter, sparsely and minutely puberulent, style branches short, about $0,4 \mathrm{~mm}$ long. The rachis and pedicels in fruit thickened and becoming fleshy, to $3 \mathrm{~mm}$ in diameter, red. Fruit ovoid, about $8 \mathrm{~mm}$ long, smooth and black.

Flowering from November to March.

Distribution: Eastern Brazil (map 15). In the coastal region from São Paulo to Paraiba up to $200 \mathrm{~m}$ altitude.

BRAzIL: BaHIA: Rio Gongoni basin, Curran 248 q (US); between Vittoria and Bahia, Sello d756 $\delta$ (B), 1184 đo (B). Paraf́ba: Areia, Coêlho de Moraes 693 A ô (US). Pernambuco: Tapera, Pickel 3580 ㅇ (NY). Rio de Janeiro: without precise locality, Burchell 2870 (L); Macahé, Brade 15786 o (B); Quinta, Glaziou 3112 ㅇ \& o (C, P); without precise locality, Gardner 5629 \& (BM, K), Gaudichaud 1088 o \& o (B, F, P), Kuhlmann 16019 o (RB), Miers 1963 o (BM), 8087 (BM); Juryuba, Miers 3966 o \& $\sigma^{\star}(\mathrm{BM})$; Trapicheiro, Peckolt 17 \& (B); Monte Videgale, Riedel 19 \% (NY, US), Schenk 1661 o (B); Canta-gallo, Riedel 303 \& (NY, US); Morro da Viuva, Schenk 3035 \$ (B); restinga de Copacabana, Ule 4383 o' (US). São Paulo: without precise locality, Frazão 13048 \& (B, S, U); Santos, Mosén 3796 đै (S).

S. hilarii is quite distinct with short leaves, serrate only on the distal half, the long inflorescences with short peduncles, the red fleshy fruiting pedicels, about $2,5 \mathrm{~mm}$ in diameter and the smooth ovoid, black fleshy fruits. This species appears to be intermediate between $S$. racemosa and $S$. guilliminiana. It seems that $S$. hilarii occurs only in a region very close to the coast at lower elevations, up to ca. $200 \mathrm{~m}$ altitude; $S$. guilliminiana is found more inland in the mountain forests at middle elevations.

15. Sorocea macrogyna Lanjouw \& W. Boer nov. spec.

Type: Krukoff 6143 \&, from Humayatá, near Tres Casas, Amazonas, Brazil (U, isotypes in A, BM, F, LIL, MO, S).

Plate X: Fig. 1, 2

Folia anguste elliptica, acuminata, apice acuto, breviter spinulosodentata, tenerrima, glabra, nervis secundariis 8-10-jugis. Inflorescentia mascula racemosa; tepala carinata; filamenta sursum angustata, reflexa; antherae emarginatae. Inflorescentia feminea breviter et compacte spicata, dum racemosa; ovarium ovulumque maximum, tylus minutus. Pedicellus fructifer diametrum $1 \mathrm{~mm}$ non attingens.

Shrubs or trees to $20 \mathrm{~m}$ tall; leafy branchlets $1,5-3,6 \mathrm{~mm}$ in diameter, minutely puberulent, glabrescent, inconspicuously lenticellate. Leaf blades narrowly ellipticoblong, 8-21 cm long, 2,8-7,3 cm broad, acuminate, the apex sharp-tipped, narrowed towards the more or less obtuse and oblique base, pergamentaceous, glabrous, the midvein impressed above, prominent below with 8-10 pairs of ascending secondary veins arching near the short spinulose-dentate margin; petioles 5-8 mm long, $0,9-1,8 \mathrm{~mm}$ in diameter, minutely and sparsely puberulent; stipules caducous, cuneate, about $4 \mathrm{~mm}$ long, their scars inconspicuous. Staminate inflorescences: 
racemose, paired or solitary in the axils of leaves or fallen leaves, 3,5-6,0 cm long, the peduncles 5-8 $\mathrm{mm}$ long, minutely hirtellous, the rachis with numerous suborbicular basally attached bracts, $0,7-1,0 \mathrm{~mm}$ broad, flowers numerous and usually distant at anthesis, about $3 \mathrm{~mm}$ wide, the pedicels to $2 \mathrm{~mm}$ long, perianth parts unequal, broadly oval, somewhat keeled, sparsely puberulent, staminal filaments thick in the lower part and narrowed towards the anthers, the narrow part and the anthers bent outward, anthers $0,7-0,9 \mathrm{~mm}$ long, emarginate. Pistillate inflorescences: spicate, becoming racemose, paired or solitary in the axils of leaves or fallen leaves, to $2 \mathrm{~cm}$ long and elongating in fruit, the peduncles about $2 \mathrm{~mm}$ long, minutely hirtellous, the rachis with numerous suborbicular or cuneate peltate or basally attached bracts, about $0,5 \mathrm{~mm}$ broad, flowers many and crowded at first, subsessile but becoming pedicellate in fruit, perianth globose, 1,2-2,0 mm in diameter, finely and sparsely puberulent, the ovary large with a very large ovule, filling nearly the whole flower, style branches slender, to $1,5 \mathrm{~mm}$ long, in fruit almost within the perianth. Fruit globose to ovoid, farinose, fruiting pedicels about $8 \mathrm{~mm}$ long and $0,7 \mathrm{~mm}$ in diameter.

Flowering from May to October.

Distribution: Upper Amazon Basin of Brazil (map 16). In forests on low terro firma and on varzea land. Also one collection from Colombia.

Brazil: Amazonas: Urucurituba, Borba, Krukoff 5969 o (U, S); near Tres Casas, Humayatá, Krukoff 6143 q (A, BM, F, LIL, MO, U, S), 6223 q (BM, F, MO, U, S); Bom Fim, Rio Juruá, Ule 5267b ơ (B, K, L, MG).

Colombia: Cundinamarca: Quebrada Carmargo, north of Apulo, Killip, Dugand \& Jaramillo 38232 \& (F, LIL, US).

The large ovule and ovary with slender style branches and the pergamentaceous leaves distinguish $S$. macrogyna from $S$. klotzschiana, the other species with spinulose leaves from the Amazon basin.

The collection from Colombia differs in the leaves with a serrate but not spinulose margin and the inflorescence condensed like some of the Paraclarisia group. In other respects it is excactly the same as Krukoff 6143 and 6223.

16. Sorocea klotzschiana Baillon, Adansonia 1: 212, t 6. 1860; Ghodat, Bull. Soc Bot. Genève sér. 2.11: 230. 1920 (misspelled as Klotzschii); Ducke, Arch. Jard. Bot. Rio de Janeiro 4: 8. 1925; Macbride, Field Mus. Bot. 13: 312. 1937.

Type: Spruce 3794 ㅇ, from Rio Negro, Amazonas, Brazil (P). Heterotypic synonyms: Sorocea grandifolia Moore, Trans. Linn. Soc. (Bot.) ser. 2.4: 476. 1895. Type: Spencer Moore 566 우, from Santa Cruz, Matto Grosso, Brazil (BM).

Sorocea castaneifolia Huber, Bol. Mus. Pará 5: 333. 1909; Chodat, Bull Soc. Bot. Genève, sér. 2.11: 230. 1920. Type: Ducke 6961 ㅇ, from Obidos, Pará, Brazil (MG).

Plate X: Fig. 3, 4

Leaves oblong-elliptic, acuminate and sharp-tipped, subcoriaceous, glandiferous below, margin spinulose-dentate. Staminate racemes: pedicels 1-3 $\mathrm{mm}$ long; flowers with fimbriate perianth parts and straight thick filaments, bearing the anthers almost at right angles. Pistillate racemes: flowers in the lower part densely puberulent; style branches $0,7-1,1 \mathrm{~mm}$ long. Fruit about 1,5 cm long, black fleshy on $2 \mathrm{~mm}$ thick pedicels. 


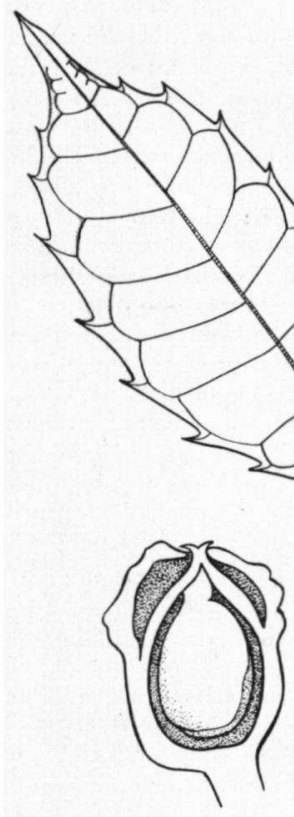

(1)

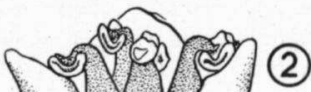

(4)
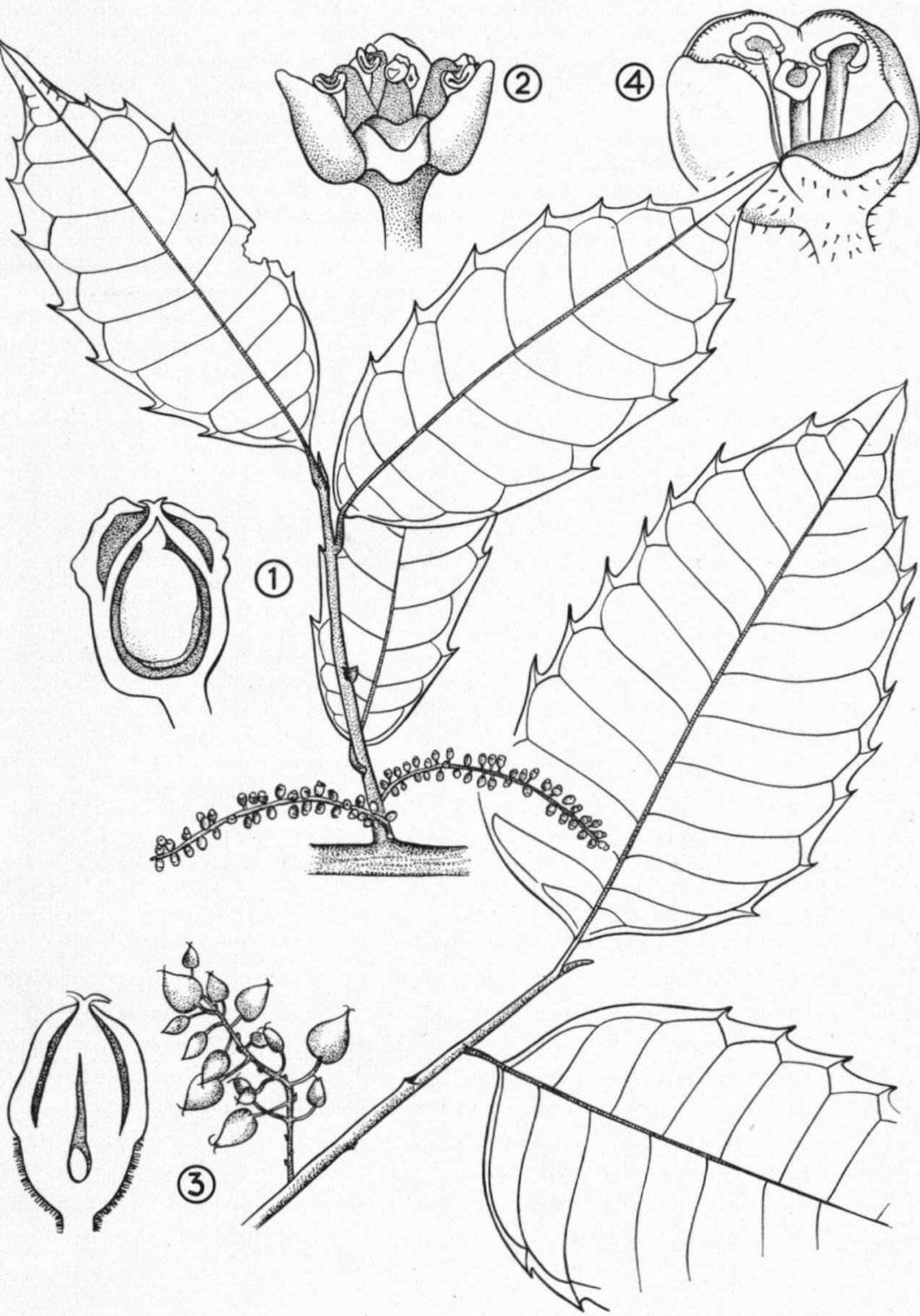

Plate X. Sorocea macrogyna: from Krukoff 6143 (fig. 1), and Ule 5267 b (fig. 2). Sorocea klotzschiana: from Ducke 13042 (fig. 3), and Moore 566 (fig. 4).

Shrubs or trees to $30 \mathrm{~m}$ tall; leafy branchlets $1,4-4,2 \mathrm{~mm}$ in diameter, minutely puberulous, soon becoming glabrous, lenticels usually inconspicuous. Leaves oblongelliptic, 10-28 cm long, 3,5-11,5 cm broad, acuminate, the apex sharp-tipped, acute or obtuse and often oblique at the base, subcoriaceous, glabrous and often lustrous above, glandiferous below, the midvein impressed above, prominent below with (9-) 11-13 pairs of secondary veins, slightly ascending or almost at right 
angles with the costa, arching upward near the spinulose-dentate margin; petioles 7-15 mm long, 1,0-2,3 $\mathrm{mm}$ in diameter, minutely puberulous or glabrous. Stipules caducous, cuneate, 4-6 mm long, their scars rather inconspicuous. Staminate inflorescences: racemose, paired or solitary in the axils of leaves or fallen leaves, 4-5 cm long, the peduncles $0,9-2,5 \mathrm{~mm}$ long, minutely hirtellous, the rachis with numerous suborbicular peltate or basally attached bracts, $0,7-1,4 \mathrm{~mm}$ broad, flowers numerous and distant at anthesis, about $3,5 \mathrm{~mm}$ wide at anthesis, the pedicels 1-3 mm long, perianth parts subequal, broadly oval, about $2 \mathrm{~mm}$ long, fimbriate and minutely puberulent, staminate filaments straight and thick, about $1,5 \mathrm{~mm}$ long and $0,7 \mathrm{~mm}$ in diameter, the anthers bent outward at right angles with the filaments, 0,8-1,0 mm long, emarginate. Pistillate inflorescences: racemose, paired or solitary in the axils of leaves or fallen leaves, $2,5-7,5 \mathrm{~cm}$ long, the peduncles 5-9 mm long, minutely hirtellous, the rachis with numerous suborbicular peltate or basally attached bracts, $0,5-0,9 \mathrm{~mm}$ broad, flowers 12 to many, in the lower part densely to scarcely puberulous, distant along the rachis, the pedicels to $3 \mathrm{~mm}$ long and elongating in fruit, perianth tube indistinctly lobed at the apex, globose to obovoid, the ovary grown to the perianth tube, densely puberulent, style branches $0,7-1,2 \mathrm{~mm}$ long, usually recurved. Fruit globose to oblongoid, about $1,5 \mathrm{~cm}$ long, in maturity black fleshy, smooth; fruiting pedicels about $1 \mathrm{~cm}$ long and $2 \mathrm{~mm}$ in diameter.

Flowering from October to April.

Distribution: Amazon basin of Brazil and Peru (map 17). In forests on the matas de terra firma.

Brazil : Amazonas: Rio Japurá, Ducke 6805 đ̊ (MG); Rio Tarumá, Ducke 810 ô (F, MG, MO, NY, RB); near Calama, Madeira River, Krukoff 1304 ㅇ (A, BM, MICH, MO, NY); near Livramento, Humayatá, Krukoff 7039 우 (A, $\mathrm{BM}, \mathrm{F}, \mathrm{MO}, \mathrm{NY}, \mathrm{U}$ ), 8849 \% (A, BM, F, MICH, MO, P, S, U); Tapuruquara, Rio Negro, Murça Pires 254 ơ (LIL, NY); along Rio Negro, Spruce 3794 9 (GH, MG, NY). Bahia: without precise locality, Bondar s.n. $\&$ (F). MatTo Grosso: Cuyabá, Malme 1148 ơ (S), 1312 o (B, GH, NY, S, U); Sta Anna da Chapada, Malme 2471 o (S); Sta Cruz, Moore 566 요 \& $\sigma^{\star}$ (B, BM, K, NY, P); Upper Machado River, near Tabajara, Krukoff 1349 \% (B, BM, MICH, MO, NY, S, U). PARÁ: Alemquer, Ducke 4938 ơ (MG); Obidos, Ducke 6961 क (MG), 8845 क (MG), 9169 ○ (MG); Faro, Ducke 13042 \& (B, RB, S, U); Serra de Santarém, Ducke 19474 o (RB), 19476 우 (B, MG, U); Obidos, Ducke 19475 ㅇ (RB).

Peru: Junis: La Merced, along Chanchamayo River, Weberbauer 1853 q (B).

This species ranks very near $S$. guilliminiana. It is readily distinguished by the more broadly elliptic-oblong leaves, the often densely puberulous, almost smooth pistillate flowers and the smooth fruits, becoming black fleshy in maturity. Moreover the two species are not sympatric and do not occur in the same ecological conditions.

The collection from Peru, Weberbauer 1853, is somewhat unusual with pistillate flowers in the lower part densely glandiferous and elongated immature fruits and may be proved to be a distinct species but in the absence of more representative material it seems better to place it with $S$. klotzschiana.

17. Sorocea guilliminiana Gaudichaud, Bot. Voy. Bonite t 74 . 1844; Trécul, Ann. Sc. Nat. Paris (Bot.) sér 3.8: t 6, f 185-188. 1847; Miquel in Martius, Fl. Bras. 4 (1): 213, t 34. 1853; Wawra, in Pr. Maxim. Ergebn. Bot. 130. 1866; Engler, Engler \& Prantl, Nat. Pflanzenfam. 3 (1): 81, f 60 a. 1888 . (P).

Type: Guillemin 131 o, from Corcovado, Rio de Janeiro, Brazil

Heterotypic synonyms: Sorocea houlletiana Gaudichaud, Bot. Voy. 
THE GENUS SOROCEA ST. HIL. (MORAC.)

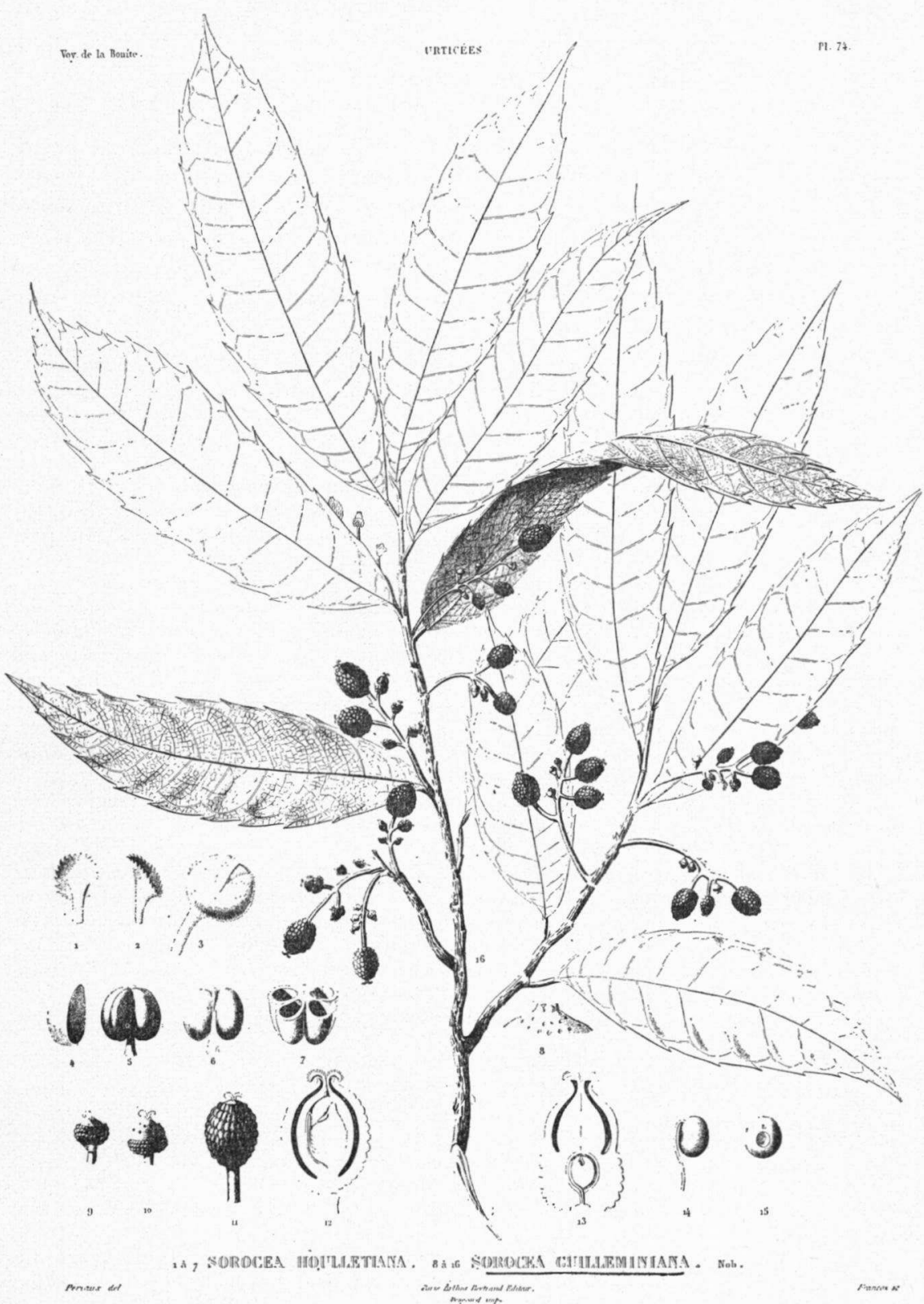

Plate XI Sorocea guilliminiana: from Gaudichaud, Bot. Voy. Bonite, 1844, t. 74. 
Bonite t 74, f 1-7. 1844; Miquel in Martius, Fl. Bras. 4 (1): 214. 1853. Type: Gaudichaud 1089 ot, from Rio de Janeiro, Brazil (P). Balanostreblus ilicifolius Kurz, Journ. Asiat. Soc. Bengal 42: 247, t19. 1873; Hutchinson, Kew Bull. 1918: 147. 1918. Type: without collector + , cult. in Bot. Garden Calcutta (GAL).

Plate XI, Plate XII: Fig. 2

Leaves elliptic-oblong to lanceolate, acuminate and sharp-tipped, subcoriaceous, glandiferous below, margin spinulose-dentate. Staminate racemes: peduncles 5-12 $\mathrm{mm}$ long, flowers about $5 \mathrm{~mm}$ wide, stamens with thick filaments and the anthers bent outward. Pistillate racemes: flowers 5-25, muriculate, style branches obtuse-ended and strongly papillose. Fruit about $7 \mathrm{~mm}$ long, muricate, on about $5 \mathrm{~mm}$ long pedicels.

Shrubs or trees to $25 \mathrm{~m}$ tall, with slender trunks, about $15 \mathrm{~cm}$ in diameter; leafy branchlets $1,3-2,7 \mathrm{~cm}$ in diameter, sparsely and minutely puberulous, glabrescent, conspicuously lenticellate. Leaves narrowly elliptic-oblong to lanceolate, 8-23 cm long, 2,4-5,5 cm broad, acuminate, the apex sharp-tipped, acute and oblique at the base, subcoriaceous, glabrous and lustrous above, sparsely glandiferous with white glandular hairs below; the midvein impressed above, prominent below with $12-16$ pairs of ascending secondary veins, arching upward near the spinulose-dentate margin; petioles 5-10 $\mathrm{mm}$ long, 1,1-1,9 $\mathrm{mm}$ in diameter, minutely and sparsely puberulous to glabrous. Stipules caducous, cuneate, about $7 \mathrm{~mm}$ long, their scars conspicuous. Staminate inflorescences: racemose, paired or solitary in the axils of leaves or fallen leaves, 5-8 cm long, the peduncles 5-12 $\mathrm{mm}$ long, sparsely and minutely puberulous, the rachis with numerous suborbicular to cuneate, usually basally attached bracts, 1-2 $\mathrm{mm}$ broad; flowers numerous and distant at anthesis, about $5 \mathrm{~mm}$ wide, the pedicels $1,5-4,0 \mathrm{~mm}$ long, perianth parts subequal, broadly oval, about $3,5 \mathrm{~mm}$ long, fimbriate, very sparsely puberulent, staminal filaments straight and thick, 0,7-1,5 mm long, 0,6-0,8 $\mathrm{mm}$ in diameter, the anthers bent outward at right angles with the filaments, about $1 \mathrm{~mm}$ long, emarginate. Pistillate inflorescences: racemose, paired or solitary in the axils of leaves or fallen leaves, $2,5-7,0 \mathrm{~cm}$ long, elongating to $12 \mathrm{~cm}$ in fruit, the rachis with numerous suborbicular peltate or basally attached bracts, $1,0-2,2 \mathrm{~mm}$ broad, flowers 5-25 per inflorescence and distant along the rachis, the pedicels about $1(-2,5) \mathrm{mm}$ and elongating in fruit, perianth tube without lobes at the apex, globose to obovoid, 2,1-3,2 mm in diameter, muriculate, sparsely and minutely puberulent, the ovary grown to the perianth tube, muriculate, minutely puberulent, style branches $0,5-1,1 \mathrm{~mm}$ long, obtuse-ended, strongly papillose. Fruit globose to oblongoid, about $7 \mathrm{~mm}$ in diameter, muricate and occasionally farinose. Fruiting pedicels about $5 \mathrm{~mm}$ long and $2 \mathrm{~mm}$ in diameter.

Flowering from October to March.

Distribution: Eastern Brazil, mainly known from Rio de Janeiro and the adjacent part of Minas Gerais (map 18). In moist forests at middle elevations.

BraziL: Espirto Santo: Serra de Cinia, Nova Venecia, Duarte 3779 ㅇ (RB), 4050 ơ (RB). Minas Gerais: Carmo, Ituiutaba, Macedo 3817 o \& đo (BM, MO, RB, S); Rio Branco, Mexia 5303 ơ (A, BM, F, GH, MICH, MO, NY, S, U); road to São Miguel, Viçosa, Mexia 5379 o (BM, F, GH, MICH, MO, NY, S, U); Est. Expt., Belo Horizonte, Oliveira $1147 \%$ (US); Lagõa Santa, Warming 1949 o \& $\delta^{t}(\mathbf{C})$. Rio de Janerro: Corcovado, Diomisio \& Occhioni 114 ơ (RB),

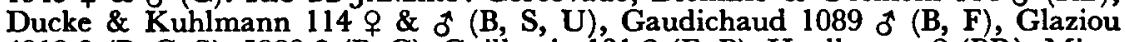
4919 \& (B, C, S), 5989 ๆ (B, C), Guillemin 131 ㅇ (F, P), Houllet s.n. ㅇ (BR), Miers 3910 o (BM), Lurchnath s.n. 우 \& o (BR), Nadeaud s.n. $q$ (P), Ule $757^{\star} \sigma^{\star}$ (B), 4369 ○ (B) ; Larangeiras, Glaziou 16356 \& (B, C), 18494 \& (B, C, F); Dist. Fed., Occhioni 244 \% (RB). 
THE GENUS SOROCEA ST. HIL. (MORAC.)

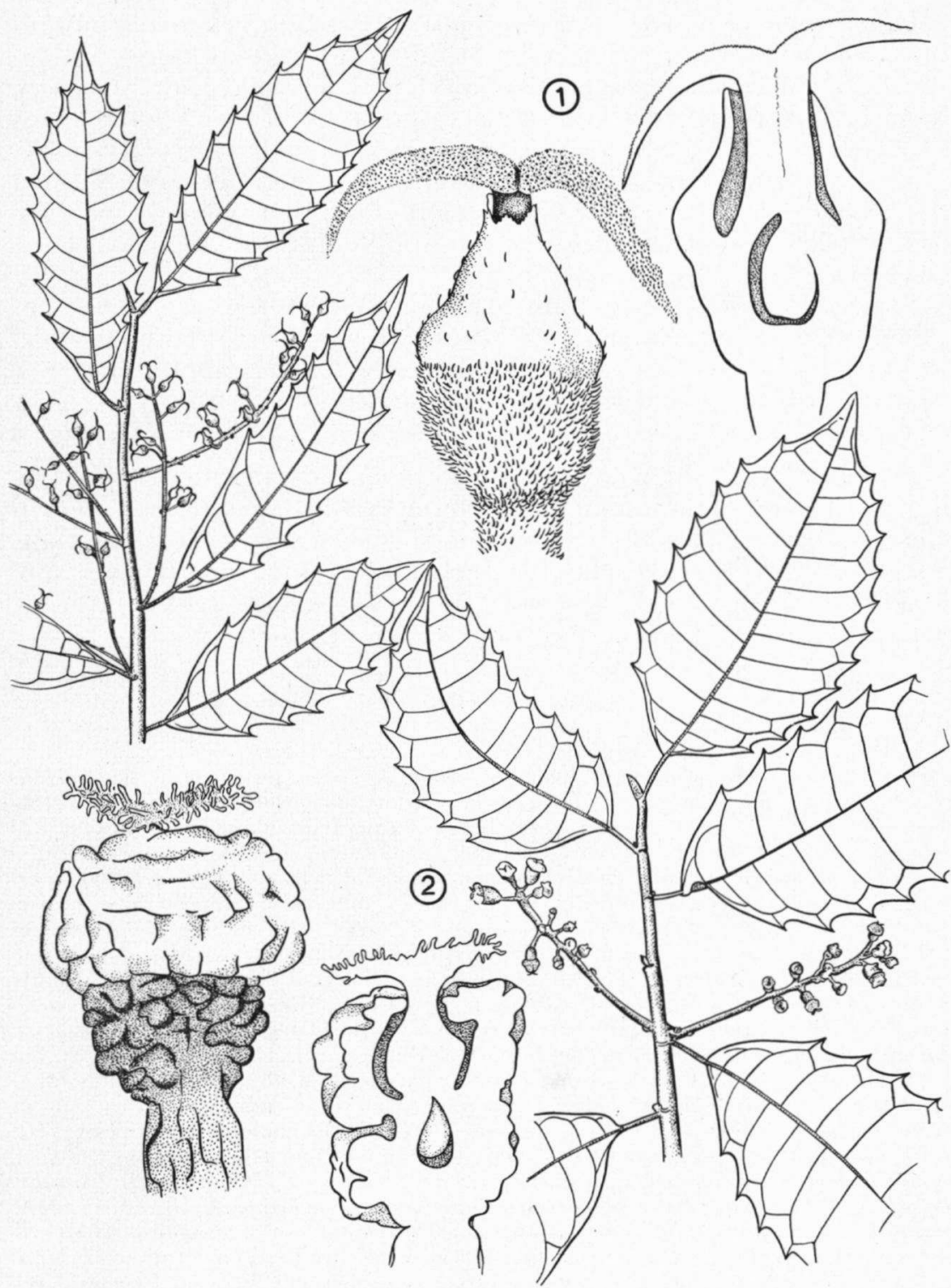

Plate XII. Sorocea bonplandii: from Pedersen 472 (fig. 1). Sorocea guilliminiana: from Ducke \& Kuhlmann 114 (fig. 2).

18. Sorocea bonplandii (Baillon) W. Burger, Lanjouw \& W. Boer nov. comb.

Basionym: Pseudosorocea Bonplandi Baillon, Adansonia 11: 296. 1875. Type: Bonpland s.n. đo, from "Campamento taya", Corrientes, Argentina (P). 
Heterotypic synonyms: Sorocea spinosa Warburg, nomen nudum, Bull. Soc. Bot. France 59 (3): 644. 1913.

Sorocea ilicifolia f. typica auct. non Miquel, Hassler, Ann. Conserv. \& Jard. Bot. Genève 21 : 120. 1919; Chodat, Bull. Soc. Bot. Genève sér 2.11: 257. 1920. Type: Hassler 567 o, from Paraguay (G).

Sorocea ilicifolia Miquel f. Laxiflora Hassler, Ann. Conserv. \& Jard. Bot. Genève 21: 121. 1919; Chodat, Bull. Soc. Bot. Genève sér 2.11: 257. 1920. Type: Hassler 12205 $\$$, from vicinity of Sapucay, Paraguay (G).

Sorocea sylvicola Chodat, Bull. Soc. Bot. Genève sér 2.11: 230, 256, f 239. 1920. Type: Balansa 1971 으, from Yaguaron, Paraguay (G). Sorocea sylvicola Chodat var. caaguazuensis Chodat, Bull. Soc. Bot. Genève sér 2.11 : 257. 1920. Type: Hassler 9413 a 오, from Caaguazú, near River Yhú, Paraguay (G).

Plate XII: Fig. 1

Leaves elliptic-oblong, 5,5-1,2 cm long, acuminate and sharptipped, margin spinulose-dentate. Staminate racemes densely puberulent; staminal filaments slender and slightly connate near the base. Pistillate racemes 9-37 $\mathrm{mm}$ long, elongating in fruit; flowers subsessile; perianth tube 4-lobed at the apex; ovary free within the perianth tube; style branches long, recurved, finely papillose.

Shrubs and small trees to $8 \mathrm{~m}$ tall; leafy branchlets $1,0-2,3(-3,8) \mathrm{mm}$ in diameter, glabrescent, conspicuously lenticellate. Leaf blades narrowly elliptic to elliptic-oblong, 5,5-12,0 (-24,0) cm long, 1,7-4,5 (-5,8) $\mathrm{cm}$ wide, acuminate with an acute tip, acute or occasionally obtuse at the base, pergamentaceous to subcoriaceous, glabrous and often lustrous above, sparsely puberulent or glabrous beneath, the midvein impressed above, prominent below with 8-18 pairs of ascending secondary veins arching upward near the spinulose-dentate margin; petioles 3-9 $\mathrm{mm}$ long, 0,7-1,4 $\mathrm{mm}$ in diameter, minutely puberulent and glabrescent. Stipules caducous or rarely tardily deciduous, lanceolate, $3,7-8,7 \mathrm{~mm}$ long, their scars conspicuous on the younger branchlets. Staminate inflorescences: racemose, paired or solitary in the axils of leaves or fallen leaves, $1,0-3,5(-4,2) \mathrm{cm}$ long, the peduncles 2-12 $\mathrm{mm}$ long, densely puberulent, the rachis with numerous suborbicular peltate or basally attached bracts $0,6-1,8 \mathrm{~mm}$ broad; flowers 10 to many and usually distant, 2,5-4,0 mm wide, pedicellate or occasionally subsessile, the pedicels to $3,5 \mathrm{~mm}$ long, the perianth parts subequal, about $2 \mathrm{~mm}$ long, minutely puberulent, the stamens bent outward at anthesis, staminal filaments $0,4-0,7 \mathrm{~mm}$ long, $0,1-0,3$ $\mathrm{mm}$ in diameter and slightly connate at the base, the anthers $0,7-1,1 \mathrm{~mm}$ long, emarginate. Pistillate inflorescences: racemose, paired or solitary in the axils of leaves or fallen leaves, 9-37 mm long and elongating in fruit, the peduncles 3-18 mm long, minutely puberulent, the rachis with numerous suborbicular peltate or basally attached bracts $0,6-1,8 \mathrm{~mm}$ broad; flowers (4-) 6-17 and usually distant, subsessile to pedicellate, the pedicels to $3 \mathrm{~mm}$ long, elongating to $18 \mathrm{~mm}$ in fruit, perianth tube minutely 4-lobed at the apex, urceolate or ovoid and narrowed above, $0,9-2,2 \mathrm{~mm}$ in diameter, sparsely appressed-puberulent, the ovary free within the perianth tube and glabrous, style branches $0,9-2,2 \mathrm{~mm}$ long and recurved, finely papillose. Fruit globose, about $1 \mathrm{~cm}$ in diameter, smooth and glabrous, becoming black.

Flowering from April through October.

Distribution: Southern Brazil, Paraguay, and northern Argentina (map 19). In forests and along rivers in the shade of other trees.

Brazil: Minas Gerais: Caldas, Mosén 1635 o (S); without precise locality, Regnell II 58 of \& ơ (B, G, S, U), Widgren s.n. ơ (B, BR, S). Paraná: Parque Nac. do Iguaçú, Duarte 1780 q (RB); Ponta Grossa, Dusén s.n. (S); Marretes, Dusén s.n. (S); Valta Grande, Dusén s.n. (S); Tamandaré, Dusén 969 a $q$ (F, 
MO, S); Therezina, Serra da Prata, Dusén s.n. (C); Carvalho, Dusén 13002 q (MO, F); Serra do Mar, Dusén 17283 ơ (F, MICH, S); S. José do Pinhaes, Hatschbach 1438 o (S). Rio DE JANeIRo: Itatiaia, Brade 12700 o (B), Dusén

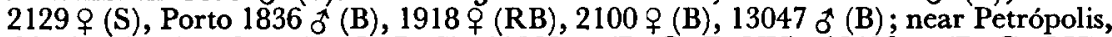

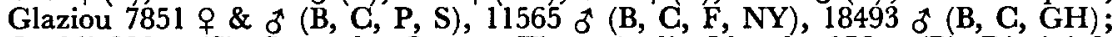
Goeldi 666 ơ (S); Serra dos Orgãos, Therezópolis, Lhotzky 176 oै (B), Rizzini \& Markgraf 10063 (RB). Rio Grande do Sul: Montenegro, S. Salvador, Friedrichs

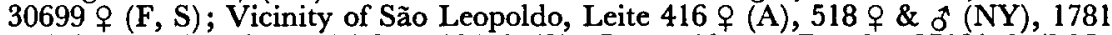
o (A); Hamburgberg, Malme 184 ㅇ (S); Pôrto Alegre, Rambo 27131 \& (MO, NY, S), 37737 of (C); Morro Sta. Teresa, near P. Alegre, Rambo 43725 o (C); Morro do Sabiá, near P. Alegre, Rambo 43746 o (LIL); Pareci Velho, Rambo 43820 o (F, LIL); Morro da Gloria, near P. Alegre, Rambo 48800 \& (MO); Vila Manresa, near P. Alegre, Rambo 57281 o (S); S. Leopoldo, Weber 33366 $\delta$ (F, S). Santa Catharina: Ibirama, Gevieski 8 o (S); Gunhas, Itajaí, Klein 824 ó (NY, S); Morro da Fazenda, Itajai, Klein 1553 oै (NY), 1572 o (NY); Morro da Ressacada, Itajaí, Klein 1586 ot (NY, S); Nova Teutonia, Plaumann 119 o \& $\delta$ (RB); Araranguá, Reitz c24 ơ (RB); Ibirama, Reitz \& Klein 3733 oै (NY); Pilões, Palhoça, Reitz \& Klein 3798 o (NY, U); Conconhaz, near Tubarão, Ule 1291 ot (B). SAo Paulo: Morro das Pedras, Iguapé, Brade 17963 ơ (B); Rio

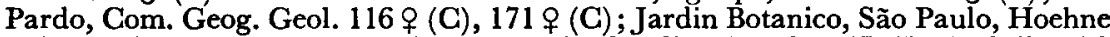
28318 i \& ơ (A, F, NY). Without precise locality, Barclay 47 (BM), Sello 178 q (B), 2188 \% (B), d 1220 कै (B), d 1235 कै (B).

Bolivia: Santa Cruz: Tres Cruces, Herzog $1630 \mathrm{~d}$ (L), $1630 \mathrm{~h}$ 우 (L).

Paraguay: Alto Paraná: St. Teresa, Bertoni 1691 o (LIL); Nacunday, Contes 9785 o (LIL); without precise locality. Fiebrig 5386 ㅇ (B), 6404 ơ (B). CAAGuzú: near River Yhú, Hassler 9413 o (B, BM, NY, P, S), 9413 b $\$$ (BM); near Caaguazú, Hassler 9413 a $q$ (MO, S). "Centralis": San Bernardino, Endlich 247 o (B), Osten 8458 o (GH); Hassler 3214 के (B, BM), 3438 o (B, NY), 12205 oै (A, L), 11883 of (A, B, BM, C, F, GH, L, MO, NY, S), 11883 a ㅇ (A, B, BM, C, F, GH, L, MO, S). DeL GuaIRÁ: Iturbe (Hernandarias), Montes 15839 ơ (LIL); Monte Santa Clara, Montes 15888 ơ (LIL). ITAPuÁ: Pirapó, Lindman A 1719 o \& $\delta$ (B, S). Misiones: La Soledad, Santiago, Pedersen 4353 q (C). Paraguarí: Serro Negro, Malme 868 \& \& $\sigma^{\star}(\mathrm{S})$; Cerro San Thomas, Osten 9146 đ (S); Villarrica, Jorgensen 3984 ㅇ (A, C, F, MO, NY, S). YaGuARón: Niandipa, Balansa 1971 字 (G, S), 3282 of (G).

Argentina: Corrientes: Bonpland s.n. $\delta(P)$; Estancia "El Plata", Ituzaingó, Meyer 6322 (LIL); Fernandez Guazú, Gen. Paz, Pedersen 3978 ㅇ (C); Santa

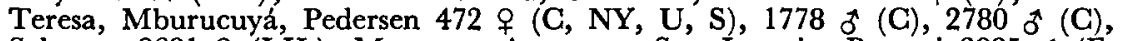
Schwarz 8681 \& (LIL). Misiones: Acaragua, San Ignacio, Bertoni 2885 of (F, MO, S); Matto Quemado, San Javier, Bertoni 3715 o (C); Acaragua, San Javier, Bertoni 3745 ơ (LIL, MO); Km 30, Eldorado, Burkart 14682 o (LIL); Loreto, Grüner 273 \& (F, GH); Puerto Aguirre, Hayward s.n. ơ (LIL); Eldorado, Meyer 6739 q (F, U), Rio Iguaçú, Niederlein 287 d 9 (B), Osten \& Rojas 8296 + (S); San Pedro, Niederlein 2206 (B), 2214 9 (B), Rodriguez 366 of (U), 537 9 (U); Cercanias de Pirayguazú, San Pedro, Schwindt 1960 ơ (LIL, S); Loreto, Baudelaria, Schwarz 4513 o (LIL, MO, U); Arroyo Apepii, San Ignacio, Schwarz 4569 ơ (F); Santo Pepó, San Ignacio, Schwarz 4823 ơ (LIL), 6127 ơ (LIL); Puerto Cazador, San Ignacio, Schwarz 4934 o (C); Rio San Antonio, Spegazzini 15454 oै (U).

Sterile material of this species is very difficult to separate from $S$. guilliminiana. The leaves of $S$. bonplandii tend to be shorter and more narrowly elliptic than those of $S$. guilliminiana. Fortunately the two species are sympatric only in Minas Gerais and Rio de Janeiro.

The very short filaments of this species are often connate near the base and seem to represent a parallel development, or perhaps a link, with subgenus Paraclarisia. After anthesis the filaments are frequently bent outwards at nearly right angles; dehiscence appearing to be downwards. 
Subgenus il Paraclarisa (Ducke) Burger, Lanjouw \& W. Boer nov. subg. (Paraclarisia Ducke, Arq. Serv. Flor. Rio de Janeiro 1 (1):2. 1939.

Shrubs and trees to $15 \mathrm{~m}$ tall; branchlets usually with short internodes and prominent leaf scars. Leaves mostly deciduous, obovate to oblong or elliptic, acute to acuminate or retuse at the apex, acute to obtuse or subcordate at the base, chartaceous to subcoriaceous or rarely membranaceous, smooth or scabrous above, sparsely to densely hispidulous beneath, the tertiairy veins usually prominent beneath, the margin entire and slightly revolute or occasionally serrulate. Staminate inflorescences: capitate or short spikes; staminate flowers with subequal perianth parts, the 4 stamens with very short $(-0,5 \mathrm{~mm})$ connate filaments and appearing sessile in the centre of the flower. Pistillate inflorescences: capitate or short spikes and racemes, not elongating in fruit; the fruit sessile or short pedicellate; the embryo with the cotyledons united almost completely.

Distributed from Venezuela and Colombia to Paraguay and northern Argentina. In moist forests, dry pampas, or inudated forests.

Subgenus Paraclarisia is distinguished by the union of the very short staminal filaments and the usually capitate inflorescences. There seems to be in this group a reduction series, i.e. congested inflorescences and reduction in flower number.

\section{Key to the species}

1. a. Leaves scabrous above, usually acute at the base; pistillate inflorescences of $1(-3)$ flower(s) subtended by strongly imbricate bracts. . . 22. S. duckei (Amazon basin)

b. Leaves smooth above, subtruncate to obtuse at the base; pistillate inflorescences of 5-12 flowers subtended by numerous irregularly imbricate bracts.

2. a. Leaves usually with a blunt apex, densely hispidulous beneath, the tertiary veins prominent; pistillate inflorescences capitate, staminate inflorescences capitate, to $25 \mathrm{~mm}$ long. . . 20. S. saxicola (Bolivia to Argentina)

b. Leaves acute to acuminate, sparsely to moderately hispidulous beneath, the tertiary veins prominulous; pistillate inflorescences capitate or short spikes, to $18 \mathrm{~mm}$ long.

3. a. Leaves conspicuously acuminate to mucronate, moderately hispidulous beneath, the upper surface lustrous; staminate inflorescences spikes, to $25 \mathrm{~mm}$ long.

19. S. sprucei (Brit. Gui. to Peru)

b. Leaves acute to short acuminate, very sparsely hispidulous to nearly glabrous beneath, the upper surface dull; staminate inflorescences capitate. 21. S. amoldoi (Guraçao)

19. Sorocea sprucei (Baillon) Macbride, Field Mus. Bot. 11: 16. 1931; Macbride, Field Mus. Bot. 13 (2): 313. 1937.

Basionym: Pseudosorocea sprucei Baillon, Adansonia 11: 296. 1875.

Type: Spruce 4483 of, from San Martín, near Tarapoto, Peru (P).

Plate XIII: Fig. 2 


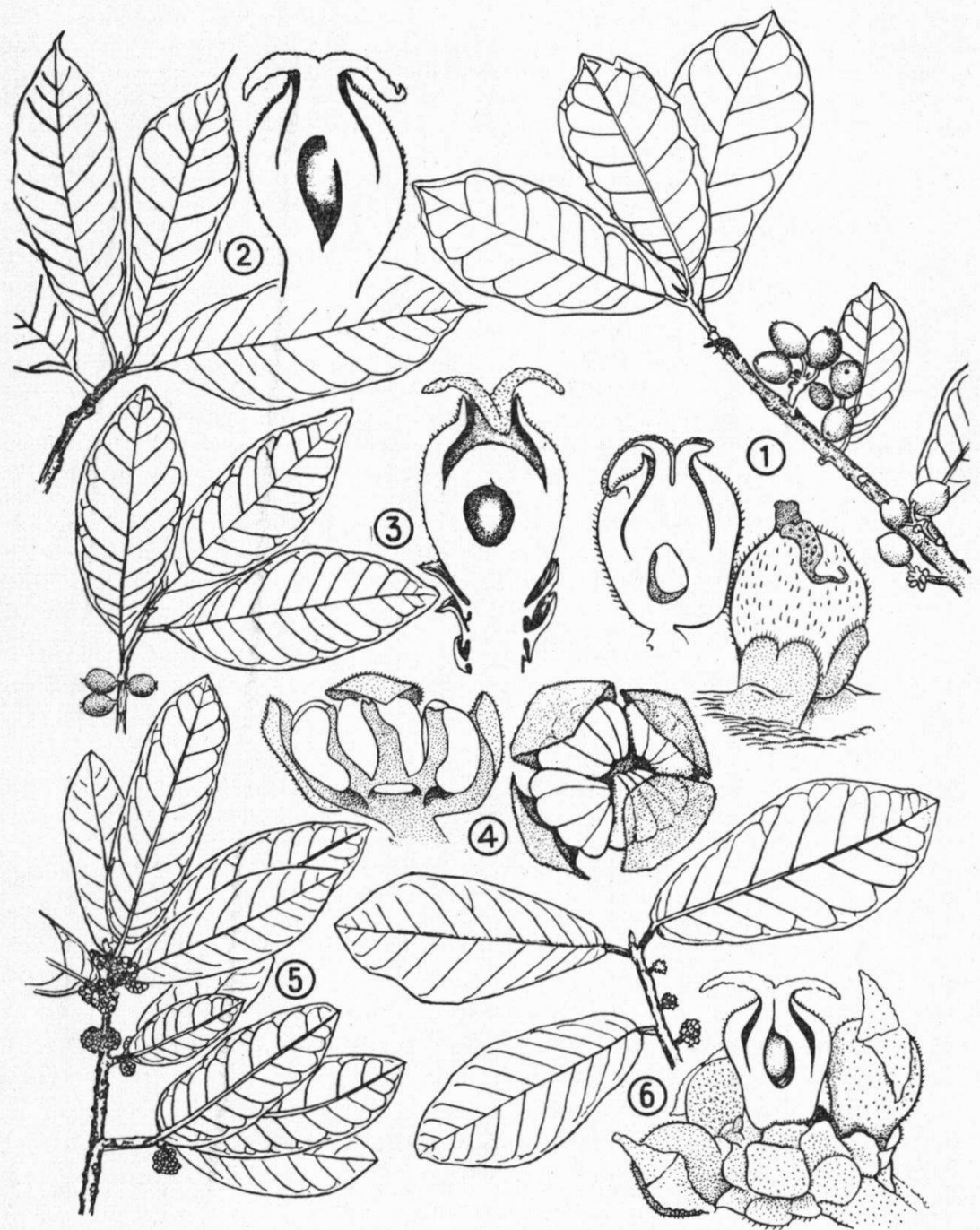

Plate XIII. Sorocea arnoldoi: from Bro. Arnoldo 2106 (fig. 1). Sorocea sprucei: from Pittier 7870 (fig. 2). Sorocea duckei: from Ducke 1532 (fig. 3). Sorocea saxicola: from Hassler 6455 (fig. 4, 5), and Hassler 12222 a (fig. 6).

Leaves deciduous, moderately hispidulous beneath, the apex acuminate, obtuse and often oblique at the base. Staminate inflorescences short spikes, to $25 \mathrm{~mm}$ long, with 9-20 subsessile flowers, staminal filaments short $(0,3 \mathrm{~mm})$. Pistillate inflorescences capitate with 4-9 flowers and many pistillate bracts, $1,4-2,0 \mathrm{~mm}$ broad, the perianth tube 4-lobed at the apex.

Small trees to $8 \mathrm{~m}$ tall with smooth gray bark; leafy branchlets $1,1-1,8(-2,6)$ $\mathrm{mm}$ in diameter, densely ascending-hispidulous at first, glabrescent, the internodes 
often short with prominent leaf scars, lenticels small and inconspicuous. Leaf blades elliptic to obovate or oblong, 5-15 cm long, 2,2-5,5 cm broad, acuminate to mucronate, acute to obtuse and often oblique at the base, chartaceous to pergamentaceous, smooth and glabrous above, moderately hispidulous beneath, the midvein plane or slightly impressed above, prominent below with 6-13 pairs of secondary veins arching upward near the entire or weakly serrate margin; petiole 5-11 mm long, 0,7-1,2 mm in diameter, hispidulous. Stipules caducous, cuneate, 3-6 (-8) $\mathrm{mm}$ long, their scars inconspicuous. Staminate inflorescences: short spikes, paired or solitary and cauliflorous on the older branches, 9-25 mm long, the peduncles $0,5-4,5 \mathrm{~mm}$ long, densely and minutely strigose, the rachis with numerous suborbicular peltate bracts $1-2 \mathrm{~mm}$ broad; staminate flowers $9-20$ and crowded, sessile or subsessile, $3,1-4,8 \mathrm{~mm}$ wide, the perianth parts broadly obovate, $1,8-2,9 \mathrm{~mm}$ long, $2,0-2,8 \mathrm{~mm}$ wide, minutely papillate-puberulent the staminal filaments connate, less: than $0,4 \mathrm{~mm}$ long and the anthers about $1 \mathrm{~mm}$ long, connective extended beyond the thecae. Pistillate inflorescences: capitate or short spicate solitary or paired in the axils of fallen leaves of the previous season, 5-12 $\mathrm{mm}$ long, the peduncles $3,2-6,8 \mathrm{~mm}$ long, densely hispidulous with numerous orbicular peltate or occasionally basally attached bracts subtending the flowers; about $1,4-2,0 \mathrm{~mm}$ broad; flowers 4-9, sessile but constricted at the rachis, the perianth tube minutely 4-lobed at the apex obovoid to ellipsoid 2,4-3,4 mm long and $2,0-2,7 \mathrm{~mm}$ in diameter, sparsely puberulent, the ovary partly grown to the perianth tube, the style branches 1,2-1,5 mm long.

Flowering in May and June.

Distribution: British Guiana, northern Brazil, Venezuela, Colombia, and eastern Peru (map 20). In forests and along stream banks.

Colombia: Santa Marta: Santa Marta region, Espina 73 (F); Bolfvar: near Usiacurí, Dugand 1213 (US).

Venezuela: Distrito Federal: lower Cotiza, near Caracas, Pittier $7870 q$ (F, GH, MICH, MO). Monagas: Caicara, F. D. Smith 221 (partly) ơ (US). British GuiAna: savanna without precise locality, Schomburgk 1239 \% \& oै (B). Brazil: Rio Branco: Surumú River, Ule 8115 o (B).

Peru: San Martín: near Tarapoto, Spruce 4483 ơ (B, C, F).

The staminate flowers of Smith's collection in Venezuela are a rather good match for the type collected by Spruce in Peru. Probably further collecting will fill in the present disjunction between northern Colombia and Spruce's Peruvian collection. Smith's collection appears to be a mixture; it is doubtfull that the leafy branchlets with retrorse uncinate trichomes belong to Sorocea.

The specimen from Rio Branco region (Ule 8115) is mentioned by Ducke as a paratype of Paraclarisia amazonica, but agrees very well with $S$. sprucei and belongs here.

20. Sorocea saxicola Hassler, Bull. Boiss. sér 2.7: 11. 1907; Hassler, Ann. Conserv. \& Jard. Bot. Genève 21: 111. 1919; Chodat, Bull. Soc. Bot. Genève sér 2.11: 233. 1920.

Type: Hassler 7338 \&, from Concepcion, Paraguay (G).

Heterotypic synonyms: Sorocea saxicola Hassler var. dentata Hassler, Bull. Boiss. sér 2.7: 12. 1907; Hassler, Ann. Conserv. \& Jard. Bot. Genève 21: 111. 1919. Type: Hassler 1071 ઈ,, from San Bernardin, Paraguay (G).

Sorocea saxicola Hassler f. subrepanda Hassler, Bull. Boiss. sér 2.7: 12. 1907. Type: Hassler $6455 \AA$, from the Cordillera Central, Paraguay (G). 
Leaves deciduous, glabrous above, densely hispidulous beneath, the tertiary veins prominent; apex and base obtuse to rounded. Staminate inflorescences capitate; anthers with the connective prolonged beyond the thecae. Pistillate inflorescences capitate; flowers with a minutely 4-lobed perianth; style branches 1,2-2,0 mm long, minutely papillate. Fruit globose, smooth, about $1 \mathrm{~cm}$ in diameter.

Much branched shrubs and trees, 6-10 m, rarely to $15 \mathrm{~mm}$ tall; leafy branchlets $1,8-3,8 \mathrm{~mm}$ in diameter with short internodes and raised leaf scars, densely hispidulous at first, glabrescent, the lenticels small and inconspicuous. Leaf blades obovate or oblong to oval or elliptic, $4-7(-13) \mathrm{cm}$ long, $1,2-4,6(-6,2) \mathrm{cm}$ broad, the apex obtuse to rounded or occasionally retuse, obtuse to rounded or subtruncate at the base, pergamentaceous to subcoriaceous, glabrous above, densely hispidulous beneath, the midvein impressed above and prominent below with 6-11 pairs of ascending secondary veins arching upward near the entire, rarely serrulate, somewhat involute margin, the tertiary veins raised and densely hispidulous; petiole $3,7-6,8(-11,0) \mathrm{mm}$ long, $0,8-1,8 \mathrm{~mm}$ in diameter, densely hispidulous. Stipules caducous, broadly cuneate, $3-4 \mathrm{~mm}$ long, their scars conspicuous on the younger shoots. Staminate inflorescences: capitate, paired or solitary in the axils of leaves or fallen leaves, 7-18 $\mathrm{mm}$ long, the peduncles $0,8-5,5(-8,0) \mathrm{mm}$ long, densely and minutely strigose with numerous orbicular peltate bracts $0,7-1,6 \mathrm{~mm}$ broad, subtending the flowers; flowers 6-19 and crowded, short-pedicellate to subsessile, about 2,5 mm long and 3,0 $\mathrm{mm}$ wide, pedicels to $1 \mathrm{~mm}$ long, the perianth parts broadly obovate, 1,8-2,6 $\mathrm{mm}$ long and about $1,6 \mathrm{~mm}$ wide, minutely puberulent, staminate filaments connate, less than $0,3 \mathrm{~mm}$ long, anthers $0,9-1,5 \mathrm{~mm}$ long with the connective frequently forming a projection at the apex of the thecae. Pistillate inflorescences: capitate, paired or solitary in the axils of leaves or fallen leaves, $6,5-16,0 \mathrm{~mm}$ long, the peduncles $3,2-8,8 \mathrm{~mm}$ long, densely and minutely strigose with numerous suborbicular peltate bracts $0,6-1,4 \mathrm{~mm}$ broad subtending the flowers; flowers 5-10 and crowded, short-pedicellate to subsessile, the pedicels to $0,8 \mathrm{~mm}$ long, obovoid to ovoid, the perianth tube minutely 4-lobed at the apex, about $3 \mathrm{~mm}$ long and $2 \mathrm{~mm}$ in diameter, minutely puberulent, the ovary usually free within the perianth tube, the style branches $1,2-2,0 \mathrm{~mm}$ long and nearly as wide at the base, the stigmatic surface minutely papillate. Fruit globose, smooth and glabrescent, becoming black, about $1 \mathrm{~cm}$ in diameter.

Flowering from August to December.

Distribution: Bolivia, Matto Grosso (Brazil), Paraguay, and northernmost Argentina (map 21). In moist or dry woods and pampas on rocky, sandy, or clayey, often saline soils.

Bolrvia: BenI: Trinidad, Cardenas $3768 \%(\mathrm{~S})$; Missiones Guarayos, Trinidad, Werdermann 2318 oै (B, S), 2542 ơ (B, S). SANTA CRUz: Monte de San Javier, Sará, Steinbach 2930 o (B, LIL); Río Palomentillas, Sará, Steinbach 6477 ơ (B, BM, F); La Perdix, Sará, Steinbach 7917 đ̊ (A, B, BM, F, GH, LIL, MO, S, U).

Brazil: Matto Grosso: Cuiabá, Malme 2302 ơ (S).

Paraguay: Cordillera de Altos, Fiebrig 182 q (A, B, F, L); Alto Paraguay,

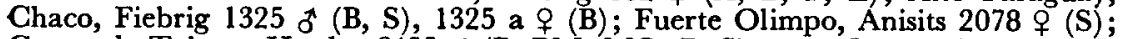
Cerros de Tobaty, Hassler $6455{ }^{*}$ (B, BM, MO, P, S); near Concepción, Hassler 7338 \& (B, C, MO, S), 7338 a $\delta$ (B, MO, S); near lake Ypacaray, Hassler 12222 f (A, B, BM, C, F, GH, L, MO, S), 12222 a \& (A, B, BM, C, F, GH, L, MO, S); Rio Ipané, near Concepción, Malme 960 o (B, GH, S); Rio Paraguay near Asunción, Balansa 1969 ㅇ (B, S); Cerro Pelado, near Paraguarí, Balansa 3192 o (L); Hihaty, Jorgensen 4502 of (A, C, F, MO, S), 4503 o (A, C, F, MICH, MO, S); Bermejo, Pilar, Meyer 16096 (LIL), 16139 (LIL); Trinidad, Morin 789 o (MICH); Oriblas, Trinidad, Rojas 1788 \% (LIL); Sierra de Amambay, Rojas 9706 \& (A); Chaco, near Asunción, Lindman A 2051 (B, S).

Argentina: Formosa: Riacho Pegro, Pilcomayo, Morel 3954 ơ (LIL). Chaco: Las Palmas, Jorgensen 2156 o (GH, MO), 2157 ơ (GH, MO); Fontana, Meyer 
272 ㅇ (LIL); Orillas Guaycurú, Meyer 1059 đ (LIL); Río Guaycurú, Mborebí, Rojas 11649 (LIL); Río Bermejo, El Colorado, Rojas 12091 \& (LIL); near Bermejo, without collector 232 \& (LIL). Corrientes: Mburucuyá, Pedersen 443 \& (C, S, U), 1208 o (C, MO, U), 1208 a ㅇ (C, MO, NY, U); Schwarz 8820 ๆ (LIL); Saladas, Laguna Soto, Schwarz 35 o (LIL, S); Pago de los Deseos, Saladas, Schwarz 8974 ㅇ (LIL); Puerto Toledo, San Cosme, Ybarrola 671 (F, LIL); Berón de Estrada, Ybarrola 3857 (LIL).

The leaves of this very peculiar species are somewhat variable: pergamentaceous to subcoriaceous, the margin entire or rarely serrulate and usually more or less involute. These forms are found on the same branch and intermediate stages occur. Therefore it seems not worthy to describe them as different taxa.

21. Sorocea arnoldoi Lanjouw \& W. Boer nov. spec.

Type: Arnoldo 2106 \&, from Guraçao (U). Plate XIII: Fig. 1

Folia fugacia, obovata vel oblonga, breviter acuminata, basi inaequalia, apicem versus leviter serrata, supra glabra, subtus sparse hispidula. Inflorescentia mascula capitata, floribus 7-15 subsessilibus. Antherae connectivo exserto, filamentis brevissimis, basi connatis. Inflorescentia feminea capitata, floribus 8-12 subsessilibus; stylus parvus; ovarium tubo perianthii infra adnatum.

Small trees; leafy branchlets $1,2-1,9 \mathrm{~mm}$ in diameter, densely hispidulous at first, glabrescent, with short internodes and raised leaf scars, the lenticels small and inconspicuous. Leaf blades obovate to oblong, $3-9 \mathrm{~cm}$ long, $1,0-4,5 \mathrm{~cm}$ broad, shortly obtuse acuminate, obtuse and oblique at the base, chartaceous, smooth above, very sparsely hispidulous beneath, the midvein impressed above, prominent below with 7-8 pairs of ascending secondary veins arching upward near the almost entire or in the upper part serrate margin, the tertiary veins prominulous above, petioles 3-7 $\mathrm{mm}$ long, 0,7-1,5 $\mathrm{mm}$ in diameter, hispidulous. Stipules caducous, cuneate, keeled, about $3 \mathrm{~mm}$ long, their scars inconspicuous. Staminate inflorescences: capitate, paired or solitary in the axils of fallen leaves, about $7 \mathrm{~mm}$ long, the peduncles about $2 \mathrm{~mm}$ long, densely strigose, with numerous suborbicular basally attached or peltate bracts, $0,7-1,5 \mathrm{~mm}$ broad, subtending the flowers, flowers 7-15 per inflorescence, crowded, subsessile, about $1,5 \mathrm{~mm}$ in diameter, the perianth parts broadly obovate, minutely puberulent, staminal filaments connate, very short, anthers with the connective prolonged beyond the thecae. Pistillate inflorescences: capitate, paired or solitary in the axils of fallen leaves, about $5 \mathrm{~mm}$ long, the peduncles about $3 \mathrm{~mm}$ long, at the base with 2 black-brown bracts, densely strigose with numerous suborbicular peltate or basally attached, long fimbriate bracts, $0,7-1,3 \mathrm{~mm}$ broad, subtending the flowers, 8-12 per in: florescence, crowded, subsessile, ovoid, about $2 \mathrm{~mm}$ long, minutely puberulent, the ovary partly grown to the perianth tube, the style branches $1,5-2,0 \mathrm{~mm}$, very slender at the apex. Fruit ovoid, smooth and glabrous, purple black, $12 \mathrm{~mm}$ long, fruiting pedicels about $5 \mathrm{~mm}$ long, $1,5 \mathrm{~mm}$ in diameter.

Flowering in August and September.

Distribution: Only known from Arnoldo's collections from Curaçao (map 22).

Curacao: Tafelberg, Arnoldo 1088 o (U), 1104 \& (U), 2106 o \& $\delta$ (U).

This species resembles $S$. saxicola from Paraguay and adjacent regions in form and size, but is distinguished by the acuminate, very sparsely hispidulous leaves, the long slender style branches and the inferior ovary. The resemblance may be the result of a convergence due to the rather dry conditions in which the two species occur. 
22. Sorocea duckei $W$. Burger nom. nov.

Based on: Paraclarisia amazonica Ducke, Arq. Serv. Flor. Rio de Janeiro 1 (1): 2. 1939; not Sorocea amazonica Miquel.

Type: Ducke 193 (H.J.B.R. 23995) q, from Genipatuba, Santarém, Pará, Brazil (R). Plate XIII: Fig. 3

Leaves deciduous, scabrous above, densely hispidulous beneath; the apex and the base acute to obtuse. Staminate inflorescences capitate, bracts $0,8-1,4 \mathrm{~mm}$ broad, tepales somewhat keeled, anthers emarginate. Pistillate inflorescences reduced to a single flower, the peduncle $1-4 \mathrm{~mm}$ long with many bracts. Fruit globose about $1 \mathrm{~cm}$ in diameter.

Shrubs or small trees to $7 \mathrm{~mm}$ tall; leafy branchlets $1,1-1,8(-2,4) \mathrm{mm}$ in diameter with short internodes and raised leaf scars, densely hispidulous at first, glabrescent, the lenticels small and inconspicuous. Leaf blades elliptic to oblong or obovate, $5-12 \mathrm{~cm}$ long, $2,0-4,8 \mathrm{~cm}$ broad, the apex obtuse to acute or occasionally subacuminate, acute or sometimes obtuse at the base, firmly chartaceous to subcoriaceous, scabrous above, densely hispidulous beneath, the costa slightly impressed above, prominent below with 6-11 pairs of ascending secondary veins arching upward near the entire, slightly involute margin, the tertiary veins slightly raised beneath and hispidulous; petioles 2,8-9,5 $\mathrm{mm}$ long, 0,7-1,3 $\mathrm{mm}$ in diameter, densely hispidulous. Stipules caducous, broadly cuneate, $2,8-4,8 \mathrm{~mm}$ long, their scars conspicuous on the young branchlets. Staminate inflorescences: capitate, paired or solitary in the axils of fallen leaves of the previous season, apparently emerging with the new leaves, 4,5-9,8 $\mathrm{mm}$ long, the peduncles 2,0-4,8 $\mathrm{mm}$ long, densely and minutely strigose, with numerous suborbicular peltate bracts $0,8-1,4$ mm broad subtending the flowers; flowers 8-17 and crowded, sessile or subsessile, about 1,5-2,5 $\mathrm{mm}$ wide, perianth parts broadly obovate and somewhat keeled, 1,4-2,2 mm long, 1,3-1,8 $\mathrm{mm}$ broad, minutely puberulent, the staminal filaments united, less than $0,4 \mathrm{~mm}$ long, the anthers about $0,8 \mathrm{~mm}$ long, emarginate. Pistillate inflorescences: usually reduced to a single flower or occasionally 2- or 3-flowered, the peduncle (pedicel) $1,2-3,8 \mathrm{~mm}$ long with numerous imbricate, basally attached or peltate bracts $0,6-1,3 \mathrm{~mm}$ broad; flowers sessile but constricted at the rachis, obovoid or ellipsoid, the perianth tube minutely 4-lobed at the apex, $1,8-5,0 \mathrm{~mm}$ long, about $2 \mathrm{~mm}$ in diameter, minutely puberulent, the ovary grown to the perianth tube, style branches broad at the base, 1,0-2,2 $\mathrm{mm}$ long, with the stigmatic surface minutely papillate. Fruit globose to broadly ellipsoid, about $1 \mathrm{~cm}$ in diameter, smooth and glabrescent.

Flowering in February and March.

Distribution: Amazon basin of Brazil (map 23). In the inundated igapó and varzeas.

Brazil: Amazonas: Rio Purus above confluence with Rio Acre, Ducke 23994 우 (B, U); Camatiá, São Paulo de Olivença, Ducke 557 ㅇ (MG, MO, NY), 1532 क (A, MG, NY, RB), 35613 \& (U); Tonantins, Rio Solimoes, Ducke 1530 कै (A, MG, NY, RB); 1531 o (NY); Pôrto Alegre, Rio Amajarí, Fróes 23120 ơ (NY, U); Parana do Xiborema, Fróes 29629 \& (NY, U). PARA: Genipatuba, Santarém, Ducke 193 ơ (B, F, U).

A reduction series of inflorescences from elongate racemes and spikes (subgenus Sorocea) to condensed capitula (subgenus Paraclarisia) is brought to its final stage in the often solitary flowered pistillate inflorescence of $S$. duckei. This inflorescence of a single flower subtended by imbricate bracts is reminiscent of Pseudolmedia or, to a lesser extent, of Clarisia. The staminate inflorescences, however, are quite typical of the subgenus. 


\section{EXCLUDED SPECIES}

1. Sorocea colombiana Standley, Trop. Woods 19: 39. 1929. = Trophis racemosa (L.) Urban ssp. meridionalis (Bureau) W. Burger

2. Sorocea ilicifolia Miquel in Martius, Fl. Bras. 4 (1): 114. 1853. See page 429

3. Sorocea mexicana Liebman, Kon. Danske Vid. Selsk. Skr. 5 (2): 335. 1851. = Trophis mexicana (Liebman) Bureau

4. Sorocea nitida (Allemao) Warburg, Bull. Soc. Bot. France 49, mém. 3: 644. 1913. Basionym: Soaresia nitida Allemao = Clarisia racemosa Ruiz et Pavon

5. Sorocea stenophylla Standley, Trop. Woods 43: 18. $1935=$ = Acanthinophyllum ilicifolia (Sprengel) W. Burger

6. Pseudosorocea poeppigii Baillon, Adansonia 11: 297. $1875=$ Acanthinophyllum ilicifolia (Sprengel) W. Burger

\section{REFERENCES}

Barllon, H. E. 1875. Adansonia 11: 296.

Chodat, R. 1920. Bull. Soc. Bot. Genève sér 2. 11: 256.

Ducke, A. 1939. Arq. Serv. Flor. Rio de Janeiro 1: 1.

Gaudichaud-Beaupré, Ch. 1844. Bot. Voy. Bonite. Paris.

KuRz, S. 1873. Journ. Asiat. Soc. Bengal 42: 247.

Mrquel, F. A. W. 1853. in Martius: Flora Brasiliensis 4 (1): 111. Munich.

Saint-Hilaire, Aug. De. 1821. Mém. Mus. Paris 7: 473. 
INDEX OF EXSICCATAE

The parenthetical numerals behind the collectors numbers refer to the species conserved in this paper.

Allen, P. A., 5059 (9); 5492 (12).

Anisits, J. D., 2078 (20).

Arnoldo, Bro., 1088, 1104, 2106 (21).

Aviles, S., 13, 26, 52 (12).

Bailey, L. H., \& E. Z., 483, 538 (12).

Balansa, B., 1969 (20); 1971 (18); 3192 (20); 3282 (18).

Baldwin, J. T., 3560 (7).

Bangham, W. N., 479, 558 (12).

Barclay, G. W., 47 (18).

Barriga, H. G., 10988 (10).

Bartlett, A. W., 8383 (2).

Bertoni, M. de B., 1691, 2885, 3715, 3745 (18).

Bettfreund, K., 273 (18).

Brade, A. C., 12700 (18); 12785 (13); 15786 (14); 17963 (18); 19746 (13).

Brenez, A. M., 4332, 5488c, 6235, 6364 (10); 12207 (8).

Buchtien, O., 1658 (6).

Burchell, W. J., 1671, 2870 (14); 6383 (16).

Burkart, A., 14682 (18).

Cardenas, M., 1757 (5); 3768 (20).

Cardona, F., 1344 (1).

Chapas-INPA, 229 (1).

Com. Geog. Geol. S. Paulo, 116, 171 (18).

Contes, -., 9785 (18).

Cooper, G. P., 554 (12)

Cooper, G. P., \& G. M. Slater, 28, 107, 174 (9).

Cufodontis, G., 200 (8).

Curran, H. M., 248 (14).

Diomisio, -., \& P. Occhioni, 114 (17).

Duarte, A., 793, 1780 (18); 3779, 4050 (17).

Ducke, A., 176 (16) ; 193, 557 (22); 810 (16); 949 (6); 1040 (1); 1530, 1531, 1532 (22); 4938, 6805, 6961 (16); 7458 (1); 7655 (6); 7670, 7959 (1); 8845 (16); 8957 (1); 9169,13042 (16); 18318 (3); 19474, 19475, 19476 (16); 23994 (22); 25254, 25255, 25256 (1), 23995,35613 (22).

Ducke, A. \& J. G. Kuhlmann, 114 (17).

Dugand, A., 490, 590, 1213 (19).

Dusén, P., 969a, 2129, 13002, 17283 (18).

Eggers, H., 14319, 14410, 14640, 15642 (11).

Endlich, R., 247 (18).

Espina, R., 73 (19).
Eugenio, J., 518 (18).

Fiebrig, K., 182 (20); 951 (18); 1325, $1325 a(20) ; 5386,6404$ (18).

Forest Service, British Guiana, 3073, 3074 (2).

Frazão, A., 13048 (14).

Friedrichs, -., 30699 (18).

Fróes, R. L., 21448 (3); 22148 (7); 22163 (3); 23120, 29629 (22).

Garcia-Barriga, H., 10988 (10).

Gardner, G., 5629 (14).

Gaudichaud, C., 262 (17); 1088 (14); 1089 (17); 1090, 1090 bis (13).

Gevieski, A., 8 (18).

Glaziou, A., 73 (14); 1137 (13); 1471 (17); 3112 (14); 4919, 5989 (17); $7851,11565(18) ; 11566,11567$ (13); 11569 (18); 16356 (17); 18493 (18); 18494 (17).

Goeldi, A., 666 (18).

Grüner, G., 273 (18).

Guillemin, A., 131 (17).

Hassler, E., 3214, 3438 (18) ; 6455, 7338, $7338 \mathrm{a}$ (20); 9413, 11883, 11883a, 12205 (18); 12222, 12222a (20).

Hatschbach, G., 1438 (18).

Hayes, S., 682, 684 (12).

Herzog, Th., 1630d, 1630h (18).

Hoehne, F. C., 28318 (18).

Holm, R. W., \& H. H. Iltis, 389 (9).

Huber, J., 6977 (14).

Jenman, G. S., 1183, 2480 (2).

Johnston, I. M., 1582, 1693 (12).

Jorgensen, P., 2156, 2157 (20); 3984 (18); 4502, 4503 (20).

Kenoyer, L. A., 324 (12).

Killip, E. P., A. Dugand, \& R. Jaramillo, 38232 (15).

Killip, E. P., \& A. C. Smith, 27531 (6).

Klein, R., 824, 1553, 1572, 1586 (18).

Klug, G., 153 (1); 739 (7); 3566 (10); 3984 (1); 4161 (4).

Krukoff, B. A., 1304 (16); 1314 (1); 1349 (16); 4954, $5084(6) ; 5290,5352$, 5513 (1); 5785 (6); 5969 (15); 5977 (1); 5982 (3); 6143, 6223 (15); 6988 (1); 7039 (16); 8157 (7); 8520 (1); 8648 (7); 8849 (16); 10819, 10932 (6).

Kuhlmann, J. G., 256 (1); 401 (7); $576,708,1103(1) ; 1517(7) ; 16019$ (14). 
Lawrence, A. E., 730 (6).

Leite, E., 416, 518, 1781 (18).

Lhotzky, J., 176 (18).

Lima, A. Santos, 49-221 (17).

Lindman, C. A. M., A 1719 (18); A 2051 (20).

Little, E. L., 6192, 6375, 6478 (11).

Little, E. L., \& R. R., 9572, 9651 (6).

Macedo, A., 3817 (17).

Malme, G. O. A., 184, 868 (18); 960 (20); 1148, 1312 (16); 2302 (20); 2471,2614 (16).

Mendonça, R., 877, 905, 1087 (17).

Mexia, Y., 5303, 5379 (17); 8260 (10).

Meyer, T., 272, 1059 (20); 6322, 6739 (18); 16096, 16139 (20).

Miers, J., 1963 (14); 3387 (13); 3684 (14); 3910 (17); 3966, 3983, 8087 (14).

Montes, J. E., 9785, 15839, 15888 (18).

Moore, S., 566 (16).

Moraes, J. G. de, 693 A (14).

Morel, I., 3954 (20).

Morin, C. V., 789 (20).

Mosén, Hj., 1635 (18); 3796 (14); 4391 (18).

Niederlein, G., 287d, 2206, 2214 (18).

Occhioni, P., 244 (17); 245, 246 (13).

Oliveira, J. E. de, 1147 (17).

Osten, C., 8458, 9146 (18).

Osten, C., \& T. Rojas, 8296 (18).

Peckolt, G., 17 (14).

Pedersen, T. M., 443 (20); 472 (18); 1208 , 1208a $(20)$; 1778, 2780, 3978, 4353 (18).

Pickel, D. B., 3580 (14).

Pires, J. M., 71 (1); 248 (7); 254 (16); $338,343,518(7) ; 555(2) ; 556(7)$; 3539 (1).

Pittier, H., 3045 (10); 3856, 4034, 4123 (12); 7870 (19); 11266,13453 (9).

Plaumann, F., 119 (18).

Poeppig, E., 2325 (1); 2563 (6); 2581 B, 2582 (1); 2683 (16); 8581 (1 \& 6).

Porto, P. C., 1836, 1918, 2100, 13047 (18).

Rambo, B., 27131, 37737, 43725, 43746, 43820, 48800, 57281 (18).

Regnell, A. F., II 58 (18).

Reitz, P. R., c 24 (18).

Reitz, P. R., \& R. Klein, 3733, 3798 (18).

Riedel, L., 19, 303 (14).

Rizzini, C. T., \& F. Markgraf, 10063 (18).

Rodriguez, F. M., 366, 537 (18).
Rojas, T., 1493 (18); 1788, 9706, 11649 , 12091 (20).

Rusby, H. H., 2217, 2578 (3).

Salvoza, F. M., 966 (12).

Schenk, H., 1425 (18); 1661, 3035 (14).

Schomburgk, R., 1239 (19).

Schwarz, G. J., 35 (20); 4513, 4569, $4823,4934,6127,8681$ (18); 8820, 8974 (20).

Schwindt, E., 1960 (18).

Seibert, R. J., 464, 566, 576 (12).

Sello, F., 178 (18); 232, 757 (17); 1184 (14); 1185 (17); 2188 (18); d 756 (14); d 1220, d 1235, d 2152 (18).

Shank, P. J., \& A. Molina R., 4384 (9); 4827 (12)

Smith, Austin, 141, 1951, 2720, 2851, 4227, A 391, NY 802, P 2313 (10).

Smith, F. D., 221 pp. (19).

Solis, M. A., 6428 (11).

Spegazzini, C., 15454 (18).

Spruce, R., 2715 (1); 3794 (16); 4220 (4); 4483 (19).

Stahel, G., 143 (2).

Standley, P. G., 28410, 28412, 29963, $31315,40797,41053$ (12).

Starry, D. E., 84, 314 (12).

Steinbach, J., 1425 (6); 2930 (20); $2939,3042,3515$ (6); 6477 (20); $6548,7272 a, 7356$ bis (6); 7917 (20).

Stern, W. L., \& K. L. Chambers, 180 (12).

Stevens, F. L., 12 (12).

Steyermark, J. A., 17494, 41801 (12).

Tessmann, G., 4016 (6); 4059, 4111 (1); 5251 (6).

Tonduz, A., 6751, 8124, 8563, 11357, 12844 (9).

Ule, E., 757 (17); 1291 (18); 4369 (17); 4383 (14); 5267 b (15); 5869, 5870 (1); $5871(6) ; 8115$ (19).

Uribe, L. U., 1221 (10).

Warming, E., 1949 (17).

Weber, N. A., 33366 (18).

Weberbauer, A., 1853 (16).

Wedel, H. von, 598 A, 961 (12); 1090 (9); 1103, 1390, 1715 (12).

Werdermann, E., 2318, 2542 (20).

Widgren, J. F., 514 (17).

Williams, L1., 2092, 2357 (7); 6803 (4); 8010 (1); 13443, 13488, 14532, 15079, $15184(2)$.

Williams, R. S., 412 (5).

Woodson, R. E., P. H. Allen, \& R. J. Seibert, 1383 (12).

Woodworth, R. H., \& P. A. Vestal, 323 (12).

Ybarrola, T. S., 671, 3857 (20). 
New names or combinations are in bold face, synonyms in italics. Description page is in bold face, illustration page in italics.

Balanostreblus Kurz, 428 ilicifolius Kurz, 464

Clarisia mollis Standley, 449

Paraclarisia Ducke, 428 amazonica Ducke 428, 473

Pseudosorocea Baillon, 428 bonplandi Baillon, 465 poepigii Baillon, 474 sprucei Baillon, 468 uaupensis Baillon, 436

Sorocea St. Hilaire, 428, 431 affinis Hemsley, 432, 453, 454 amazonica Miquel, 431, 438, 440, 473 arnoldoi Lanjouw \& W. Boer, 428, 430, 432, 469, 472

bonplandii (Baillon) W. Burger, Lanjouw \& W. Boer, 430, 432, 465, 465

briquetii Macbride, 430, 431, 441, 442

castaneifolia Huber, 460

colombiana Standley, 474

cufodonti $W$. Burger, 431, 447, 448

cuspidata Warburg, 437

dentata Huber, 437

duckei $W$. Burger, 430,432, 473, 469

grandifolia Moore, 460

grandis Warburg, 455

guayanensis W. Burger, 431, 439, 442

guilliminiana Gaudichaud 428, 430, 432, 462, 463, 465

hilariana (Cazaretto) Bureau, 457

hilarii Gaudichaud, 432, 457, 4.58 hirtella Mildbraed, 431, 441, 443, 444

houlletiana Gaudichaud, 462

ilicifolia Miquel, 429, 474

$\beta$ hilarii (Gaudichaud) Miquel, 457

var. laxiflora Hassler, 466

f. typica Hassler, 466

klotzschiana Baillon, 432, 460, 461

macrogyna Lanjouw \& W. Boer, 432, 459, 461

macrophylla Gaudichaud, 455

mexicana Liebman, 474

muriculata Miquel, 431, 436, 438, 445

nitida (Allemao) Warburg, 474

opima Macbride, 430, 431, 445, 446

pileata W. Burger 430, 431, 442, 442

pubivena Hemsley, 431, 445, 449, 451, 452

racemosa Gaudichaud, 430, 432, 455 , $456,458,459$

sarcocarpa Lanjouw \& W. Boer, $432,452,454$

saxicola Hassler, 428, 430, 432, 469, 470, 472

var. dentata Hassler, 470

f. subrepanda Hassler, 470

spinosa Warburg, 466

sprucei (Baillon) Macbride 428, 432, 468,469

steinbachii Mildbraed, 443

stenophylla Standley, 474

sylvicola Chodat, 429, 466

var. coaguazuensis Chodat, 466

trophoides W. Burger, 431, 450, 451

uaupensis (Baillon) Macbride, 436

ulei Warburg, 443

uriamen Martius, 457

Trophis hilariana Cazaretto, 457

macrostachya Donnell Smith, 449 